\title{
Land and Water Resources for Environmental Research on the Oak Ridge Reservation
}

\author{
R. C. Dahlman \\ J. T. Kitchings \\ J. W. Elwood
}

Publication No. 935, Environmental Sciences Division

\section{OAK RIDGE NATIONAL LABORATORY}




\section{DISCLAIMER}

This report was prepared as an account of work sponsored by an agency of the United States Government. Neither the United States Government nor any agency Thereof, nor any of their employees, makes any warranty, express or implied, or assumes any legal liability or responsibility for the accuracy, completeness, or usefulness of any information, apparatus, product, or process disclosed, or represents that its use would not infringe privately owned rights. Reference herein to any specific commercial product, process, or service by trade name, trademark, manufacturer, or otherwise does not necessarily constitute or imply its endorsement, recommendation, or favoring by the United States Government or any agency thereof. The views and opinions of authors expressed herein do not necessarily state or reflect those of the United States Government or any agency thereof. 


\section{DISCLAIMER}

Portions of this document may be illegible in electronic image products. Images are produced from the best available original document. 


\title{
Printed in the United States of America. Available from National Technical Information Service \\ U.S. Department of Commerce 5285 Port Royal Road, Springfield, Virginia 22161 \\ Price: Printed Copy $\$ 5.00$; Microfiche $\$ 3.00$
}

\begin{abstract}
This report was prepared as an account of work sponsored by the United States Government. Neither the United States nor the Energy Research and Development Administration/United States Nuclear Regulatory Commission, nor any of their employees, nor any of their contractors, subcontractors, or their employees, makes any warranty, express or implied, or assumes any legal liability or responsibility for the accuracy, completeness or usefulness of any information, apparatus, product or process disclosed, or represents that its use would not infringe privately owned rights.
\end{abstract}


ORNL/TM-5352

Distribution Category UC-11

LAND AND WATER RESOURCES FOR ENVIRONMENTAL RESEARCH ON

THE OAK R.IDGE RESERVATION

R. C. Dahlman, J. T. Kitchings, and J. W. Elwood, Editors

With Contributions From:

J. M. Bird

B. G. Blaylock

R. L. Burgess

B. E. Dinger

J. 0. Duguid

W. F. Harris

S. V. Kaye

D. J. Nelson

D. E. Reichle

E. G. Struxness

H. E. Walburg

Environmental Sciences Division

Oak Ridge National Laboratory

and

Comparative Animal Research Laboratory

Publication No. 935, Environmental Sciences Division

Comparative Animal Research Laboratory (CARL)

Oak Ridge, Tennessee 37830

operated by

Institute of Agriculture,

University of Tennessee

for the

Energy Research and Development Administration under

Contract No. AT-40-7-GEN-242

Date Published: January 1977

OAK RIDGE NATIONAL LABORATORY

Oak.Ridge, Tennessee 37830

operated by

UNION CARBIDE CORPORATION

for the

ENERGY RESEARCH AND DEVELOPMENT ADMINISTRATION

Contract No. W-7405-eng-26
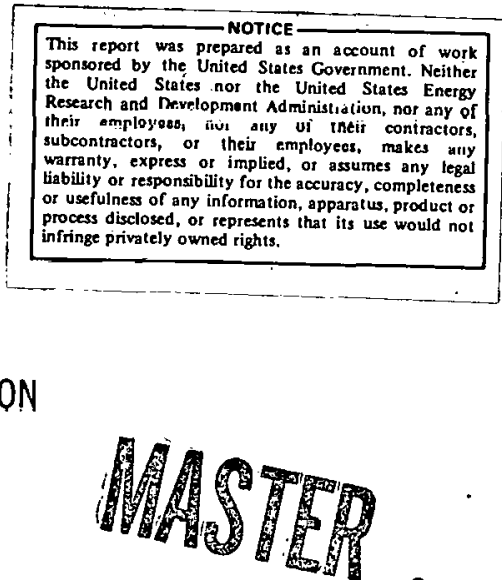
THIS PAGE

WAS INTENTIONALLY

LEFT BLANK 


\section{ACKNOWLEDGMENTS}

The extensive information presented in this document has been compiled from many hours, days and years of effort by members of the Environmental Sciences Division. Their anonymous contributions, however large or sma11, are important, greatly appreciated and acknowledged. Technical assistance from Linda Mann and from Rod Strand was very helpful. Assistance from stenographers and the Editorial Production Office is gratefully appreciated, in particular, from Joe Marie Davis, Anne Reinoeh 1, and Susan Sampson who diligently typed several drafts of the report, and from Linda Littleton and Natalie Tarr who made valuable editorial contributions. Compiling the species list in a computer file was greatly aided by Norma Yost's conscientious efforts with the key punch and PDP-10. 


\section{THIS PAGE \\ WAS INTENTIONALLY \\ LEFT BLANK}




\section{ABSTRACT}

DAHLMAN, R. C., J. T. KITCHINGS, and J. W. ELWOOD (eds). 1976. Land and water resources for environmental research on the Oak Ridge Reservation. ORNL/TM-5352. Oak Ridge National Laboratory, Oak Ridge, Tennessee. $\mathrm{pp}$.

Resources for environmental research on the Oak Ridge Reservation are analogous to the highly complex, physical and engineering facilities of the Oak Ridge National Laboratory. Consequently, land and water resources have been committed to comprehensive research for the purpose of providing relevant, scientific insights on environmental problems associated with ERDA's programs. Diverse aquatic, terrestrial, and agricultural ecosys tems are designated for short- and long-term research related to environmental impacts or benefits of different energy technologies. Examples of ecosystems employed in this research include hardwood and pine forests, grassland and pastures, free-flowing streams and impounded reservoirs, field plots, contaminated environment natural areas, an array of animal habitats, and calibrated watersheds. Some of the characteristic biota of habitat and ecosystems are described in the document. Documentation and planning for use of these lands, waters, and biotic resources also respond to the broad issue of appropriate usage of Federal lands. 
THIS PAGE

\section{WAS INTENTIONALLY LEFT BLANK}


$\underline{\text { Page }}$

ACKNOWLEDGMENT .......................... ...

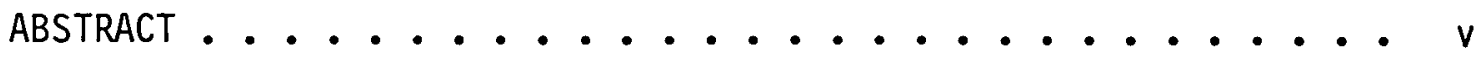
LIST OF FIGURES ................. ix LIST OF MAPS .................... ix LIST OF TABLES ....................... xi

NEED AND PURPOSE FOR DOCUMENTING LAND AND WATER RESOURCES FOR

ENVIRONMENTAL RESEARCH ............... 1 .

GEOLOGY OF THE OAK RIDGE RESERVATION ........... 3 Geology .................. 3

Seismic Characteristics ............ 4

AGRICULTURE AND FOREST RESOURCES ............ 6

Agricultural Productivity Potential ........ 6

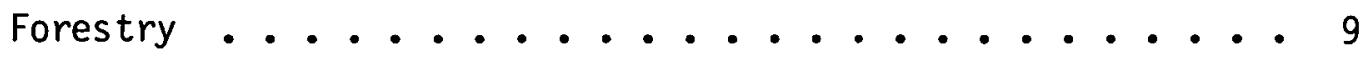

Silvicultural Management Practices ......... 9

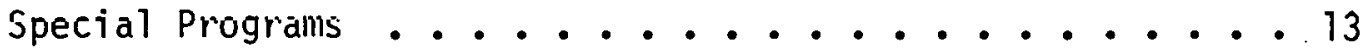

AQUATIC ENVIRONMENTS ON AND CONTIGUOUS TO THE OAK RIDGE

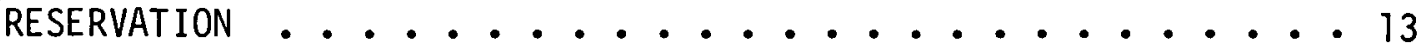

Runoff Characteristics of 0ak Ridge Catchment Basins ... 15

Clinch River ................... 15

Bearden Creek Embayment . . . . . . . . 17

Walker Branch Embayment . . . . . . . . . 17

McCoy Branch Embayment ............. 20

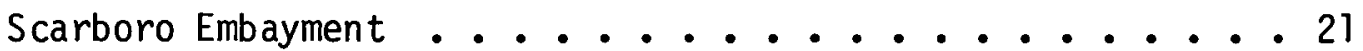

While 0ak Creek Drainage ............ 21

Poplar Creek Drainage Basin . . . . . . . . . 22

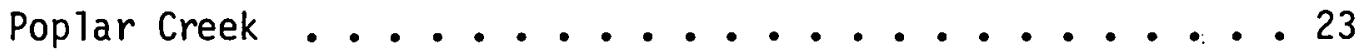

East Fork Poplar Creek .............. 23

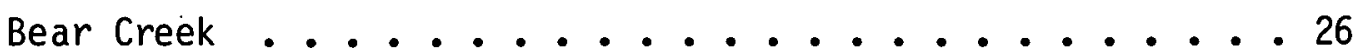

VEGETATION RESOURCES OF THE OAK RIDGE RESERVATION ...... 26 
HABITATS OF ANIMALS OF THE OAK RIDGE RESERVATION . . . . . 30 Hardwood--Mixed Hardwood Habjtat ......... 30 Pine Plantation Habitat .............. 35 0ld-Field and Grassland Habitat ........... 36 Unique or Endangered Vertebrate Species . . . . . . 36 AQUATIC BIOTA OF THE OAK RIDGE RESERVATION . . . . . . . 36 Phytoplankton in the Clinch River .......... 56 Periphyton in the $\mathrm{Clinch}$ River ......... 56 Zooplankton in the $\mathrm{Clinch}$ River ........... 56 Benthic Macroinvertebrates in the Clinch River ..... 57 Macrophytes in the Clinch River......... 57 Fish in Clinch River ............. 57 Biota of streams on the Uak Ridge Reservation ....... 58 IMPORTANT NATURAL AREAS AND ARCHAEOLOGICAL SITES OF THE OAK RIDGE RESERVATION . . . . . . . . . . . . 59

RESOURCES AND FACILITIES FOR RESEARCH IN THE ENVIRONMENTAL

AND AGRICULTURAL SCIENCES

Research Sites and Facilities used by the Environmental

Sciences Division............ 68 Research Facilities of the Comparative Animal Research Laboratory (CARL) . . . . . . . . . 75

FUTURE RESOURCE REQUIREMENTS FOR PROGRAMMATIC RESEARCH IN ENVIRONMENTAL SCIENCES . . . . . . . . . . . . . 78 


\section{LIST OF FIGURES}

Figure

Page

1 White 0ak Creek drainage ............ 16

2 Portion of Melton $\mathrm{Hill}$ Reservoir with four embayments bounding the Oak Ridge - ERDA Reservation. Embayments are associated with Bearden Creek, Walker Branch, McCoy Branch and Kerr-Hollow Branch ............ 18

3 Walker Branch Embayment, Melton Hill Lake, Tennessee . . . 19

4 East Fork Poplar Creek drainage . . . . . . . . 24

5 Bear Creek drainage .............. 25

\section{LIST OF MAPS}

Map

Page

1 Geology map ..................... 5

2 Land-type suitability for agriculture . . . . . . 8

3 Forestry compartments . . . . . . . . . . 10

4 Aquatic environments on and contiguous with the Oak Ridge ERDA Reservation .............. 14

5 Unique natural and cultural areas .......... 61

6 Terrestrial research areas ........... 65

7 Aquatic research areas ............ 67

8 CARL programmatic land . . . . . . . . . 69

Plate

1 General Vegetation Cover of the ERDA Oak Ridge Reservation Tennessee .................. 27 


\section{THIS PAGE}

WAS INTENTIONALLY

LEFT BLANK 


\section{LIST OF TABLES}

Table

Page

1 Predicted site seismic characteristics . . . . . . 7

2 Typical habitat types for animals and birds of the Oak Ridge Reservation ............. 31

3 Species found in different Aquatic Habitats of the Oak Ridge Reservation ..............

4 Summary of areas used for established programs of Environmental and Agricultural Research ........ 60

5 Programmatic lands assigned to CARL . . . . . . 76 
NEED AND PURPOSE FOR DOCUMENTING LAND AND WATER RESOURCES FOR ENVIRONMENTAL RESEARCH ${ }^{1}$

A comprehensive description of land and water resources at 0ak Ridge is developed because the availability and use of these resources for environmental assessment research is essential if the Energy Research and Development Administration (ERDA) is to achieve its goals of energy independence for the nation while exerting minimal impact on the environment. One goal of the National Plan for Energy Research and Development is to provide an examination of potential environmental consequences for each energy technology developed. Potential impacts can be examined from concurrent environmental research in representative environments such as those afforded by the Oak Ridge Reservation.

Factors considered in documenting land and water resources include:

(1) guarantees for long-term human health and safety within the boundaries of the reservation,

(2) the maintenance of long-term environmental quality in ecosystems in proximity to developing energy technology,

(3) assuring the integrity of field facilities for conducting environmental research on the Reservation,

(4) the development of ecological information for establishing availability, needs, and priorities of 1 and use under competing demands by environmental, urban, agricultural, silvicultural, and industrial sectors,

(5) education and training of environmental scientists.

Information devcloped in this report provided input to ERDA's Land Use Plan for the 0ak Ridge Reservation. ${ }^{2}$ Documentation of 1 and and water resources responds to the broad issue of appropriate usage of Federal lands and to the long-term need for responsible policy and planning as expressed by the President's Council on Environmental Quality (CEQ).

"To define and achieve good use of land and water may well be the most fundamental of all environmental objectives. In the broadest sense, the way in which we use our land determines the way in which our society functions. Land is the basic source of our food, fiber, shelter, water, and oxygen. Sound land use is fundamental to preserving stable ecosystems, to controlling pollution, and to creating the political, social, and economic structure of our snciety."

\footnotetext{
${ }^{3}$ Environmental is used comprehensively to include natural ecological relationships, abiotic characteristics of the earth's biosphere, agroecological relationships, and social-cultural aspects.

${ }^{2}$ Oak Ridge Reservation Land-Use Plan, Oak Ridge Operations Technical Information Center, ERDA, ORO-748. 1975.
} 
The availability and long-term commitment of representative and otherwise suitable land and water resources for environmental research is essential to the effectiveness of the current ERDA research mission at Oak Ridge. Concomitantly it is also important to recognize that expanded ERDA responsibilities will produce increasing demands on 1 and, water, and other environmental resources of the Oak Ridge Region. Opportunities for advancing ERDA's programmatic research are exceptional at Oak Ridge because of the availability of the existing environmental resources and facilities of the Oak Ridge Environmental Research Park. Important examples are:

(1) terrestrial ecological research sites and facilities,

(2) aquatic research sites and facilities,

(3) forest and wildlife management,

(4) agricultural activities and comparative animal research (CARL), and

(5) new facilities for long-term research.

Some additional attributes which enhance the expanded opportunities for assessing the potential impact of major technological actions are:

(1) ecological resource reference areas,

(2) diverse ecosystems representing biotic heterogeniety,

(3) regional ecosystem reference types, including natural and manipulated areas,

(4) unique natural areas,

(5) security of land ownership,

(6) archaeological antiquities,

(7) topographic, hydrologic, and soil characteristics, and

(8) physical facilities, supporting staff, and services.

The purpose of the environmental research program on the Oak Ridge Reservation is to provide relevant, scientific insights into environmental problems associated with ERDA's programs. The currentiy existing resources, facilities, and attributes that enable comprehensive environmental research are the result of prior planning efforts. Future planning of the use of the Reservation's resources ensure that sufficient and appropriate areas are available for experimental purposes consistent with immediate and future priorities and objectives of the ERDA mission. Research resources have been identified in this report on the basis of current research objectives, on requirements for experimental areas based on five-year research plans, and on anticipation of longer-term programmatic directions of environmental research. Selection of alternate research sites and facilities is based on the need for replication of habitat types and on required experimental conditions consistent with short- and long-term research objectives. Expansion of plant operations is also considered in environmental resource planning in order to facilitate impact assessment of new technology development consistent with the ERDA mission.

Environmental research programs are analogous to the highly complex, excellent and costly physical research and production facilities located on the 
Reservation. Because of their value, land and water resources on the Reservation retain a high priority for such uses, particularly as new technologies are implemented on the Reservation. Land and water resources offer continued technological research opportunity, yet simultaneous environmental surveillance of operations is required. Site descriptions, locations, and characterizations are provided for terrestrial, aquatic, and agricultural research facilities of the Oak Ridge Reservation.

The Energy Research and Development Administration's 0ak Ridge Reservation currently occupies 37,000 acres $(15,000 \mathrm{ha})$ adjacent to the City of Oak Ridge. This area is part of the original 92-sq-mile $\left(238 \mathrm{~km}^{2}\right)$ tract purchased by the Manhattan Engineering District of the U.S. Army Corps of Engineers in 1942 for an atomic energy development and production center. About $80 \%$ of the Oak Ridge Reservation lies within Roane County, Tennessee, whereas the remaining segment lies to the northeast in Anderson County, Tennessee. The eastern and southern boundaries of the reservation are defined by the Melton Hill Reservoir of the Clinch River. The western boundary is formed by the Clinch River backwaters of the Watts Bar Reservoir on the Tennessee River. Blackoak Ridge and the City of Oak Ridge provide the northern boundary.

\section{GEOLOGY OF THE OAK RIDGE RESERVATION}

Geology

The Oak Ridge Reservation is in the Tennessee section of the Ridge and Valley province and is underlain by consolidated marine sediments of Paleozoic age. ${ }^{3}$ The topography is characterized by subparallel northeasttrending ridges and valleys and reflects the geologic structure of the area, which consists of generally southeast-dipping strata. The different lithologies of the formations result in different rates of weathering and erosion. The more resistant ridge-producing formations are the Rome formation, the Knox group, the Rockwood formation, and the Fort Payne chert. Most of the valleys are underlain by the Conasauga group and the Chickamauga limestone.

The western part of the Tennessee section of the Ridge and Valley province is structurally characterized by major subparallel thrust faults that trend northeast and dip southeast. Along most of these faults, the Rome formation has been thrust over younger formations, which causes repetition of the geologic sequence within the area. The two major faults on the reservation are the Copper Creek fault and the White Oak Mountain fault. The latter exhibits several subsidiary features, including branch faults, a syncline, and two slices of dolomite of the Knox group. There is no evidence of recent displacement along either of the faults.

\footnotetext{
${ }^{3}$ Summarized from W. M. McMaster, Geologic Map of the Oak Ridge Reservatiọ!l, Tennessee, ORNL/TM=713, Oak Ridạe Natinnal Laboratory, Oak Ridge, Tonnessee, Nüv. 25, 1963.
} 
The Reservation is underlain by nine geologic formations ranging in age from Cambrian to Mississippian (Map 1). The formations are of sedimentary origin: limestone, dolomite, sandstone, and shale. From oldest to youngest, the formations are the Rome formation, the Conasauga group, the Knox group, the Chickamauga limestone, the Reedsville shale and Maury formation, and the Fort Payne chert.

The Rome formation is a fine-grained shaly sandstone that is generally well cemented. Its ability to hold and transmit groundwater is due almost entirely to fractures. However, because of the composition of the formation, the fractures have not been enlarged by solution.

The Conasauga group is primarily silty, slightly calcareous shale interbedded with thin limestone units. The permeability seems to be associated with changes due to weathering of the rock above and somewhat below the water table. Where the shale is saturated, movement of groundwater is concentrated in a zone near the water table and perhaps locally deeper along some fractures. The fractures in the Conasauga group, and therefore the permeability, are evenly distributed; this results in a more uniform flow of groundwater than occurs in other formations.

The Knox group is composed largely of thick beds of dolomite and limestone, and, where it is unweathered and undeformed, it has low porosity and low permeability. However, where it has been fractured by folding or faulting, its permeability has been greatly increased. In many places these fractures have been enlarged by solution, and large openings have been formed. Sinkholes and caverns are common. These openings give rise locally to large springs and wells of high capacity, al though there are wells that are almost dry. The permeability and porosity of the formation are unevenly distributed and have been localized by fracturing and later solution by groundwater movement.

The Chickamauga limestone. is composed largely of thin beds of shaly limestone and shale. The porosity of the formation is low; fractures have been enlarged by solution but not, however, to the extent of the cavernous knox group. These fractures and solution channels form a network of open channels and voids which permit the free movement of groundwater.

Seismic Characteristics

The ERDA Oak Ridge reservation is located in Seismic Zone 2 of the United States. The site lies in the Southern Appalachian Seismo-Tectonic province, which is characterized by a series of northeast- to southwesttrending folds and thrust faults. in Paleozoic rocks. The region has been the source of continuing minor seismic activity; however, no correlation between seismic events and known tectonic structures has been confirmed.

Forty (40) recorded earthquakes have occurred within 155 miles (250 $\mathrm{km}$ ) of the site. The most severe local earthquake occurred northeast of Knoxville on March 28, 1913, with an epicentral modified Mercalli intensity 


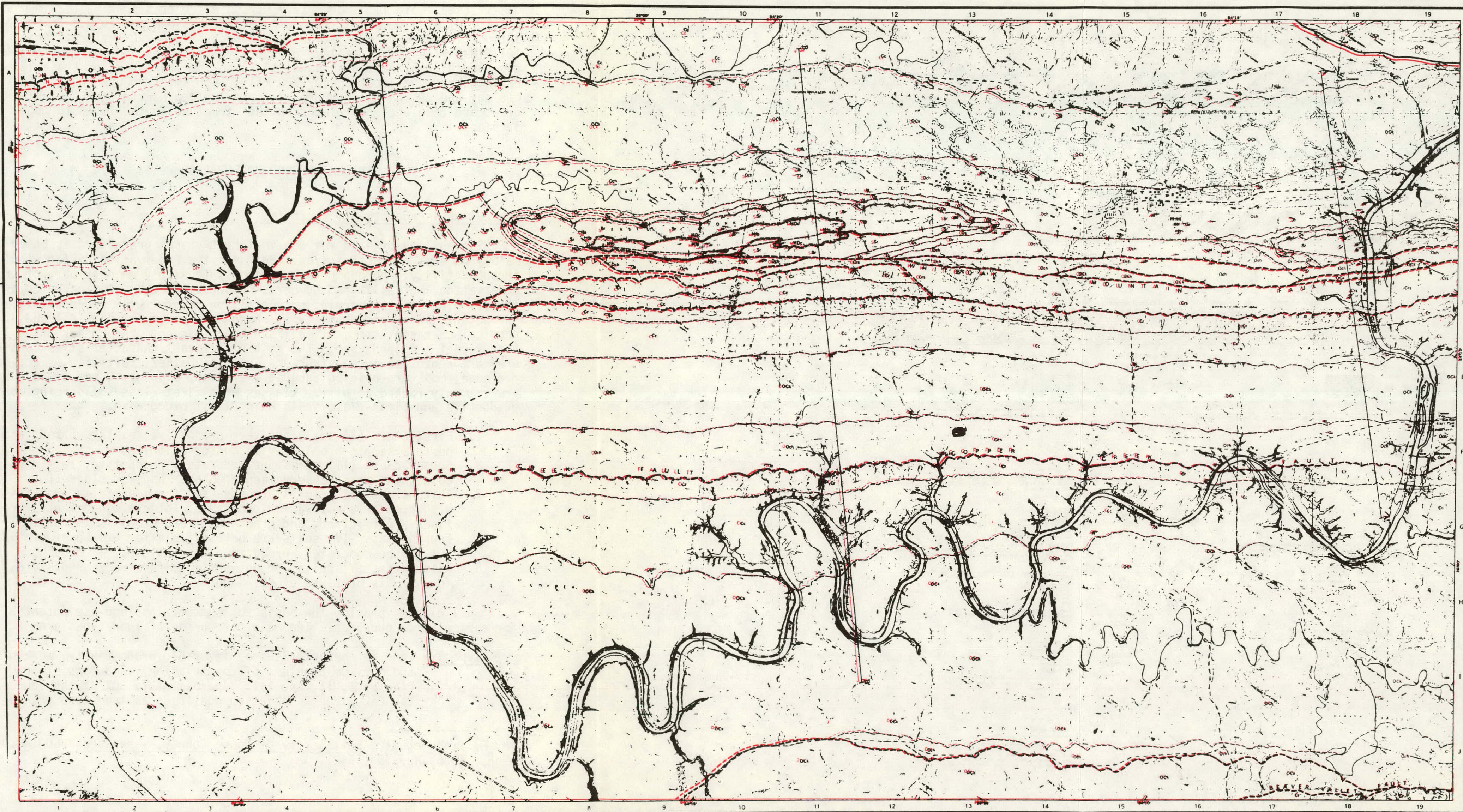




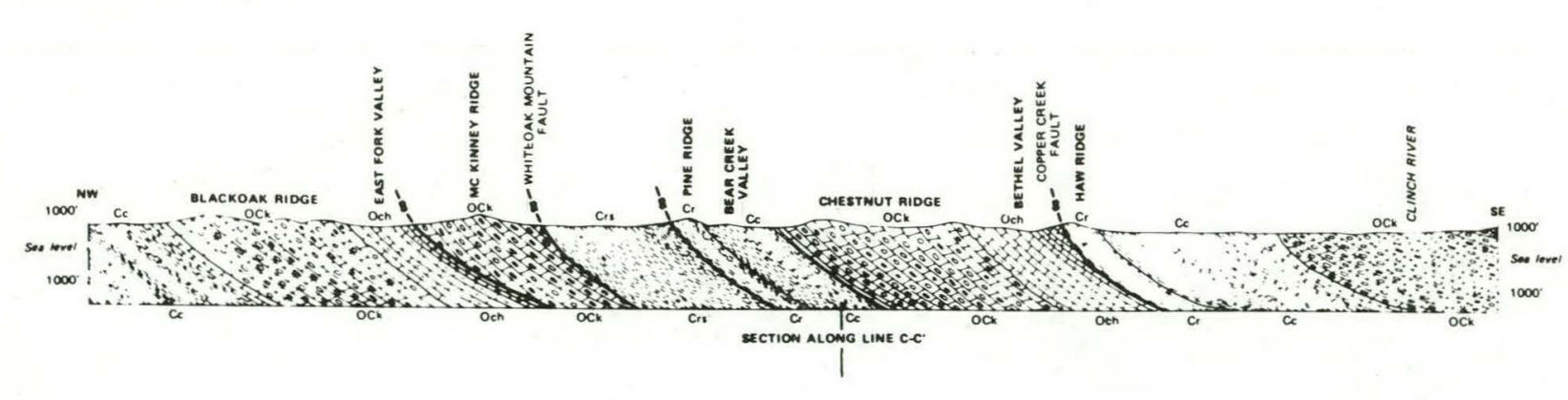

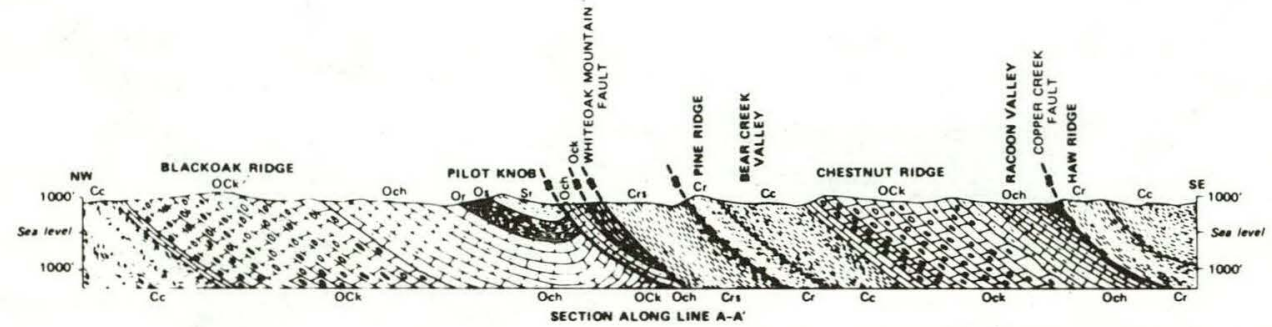
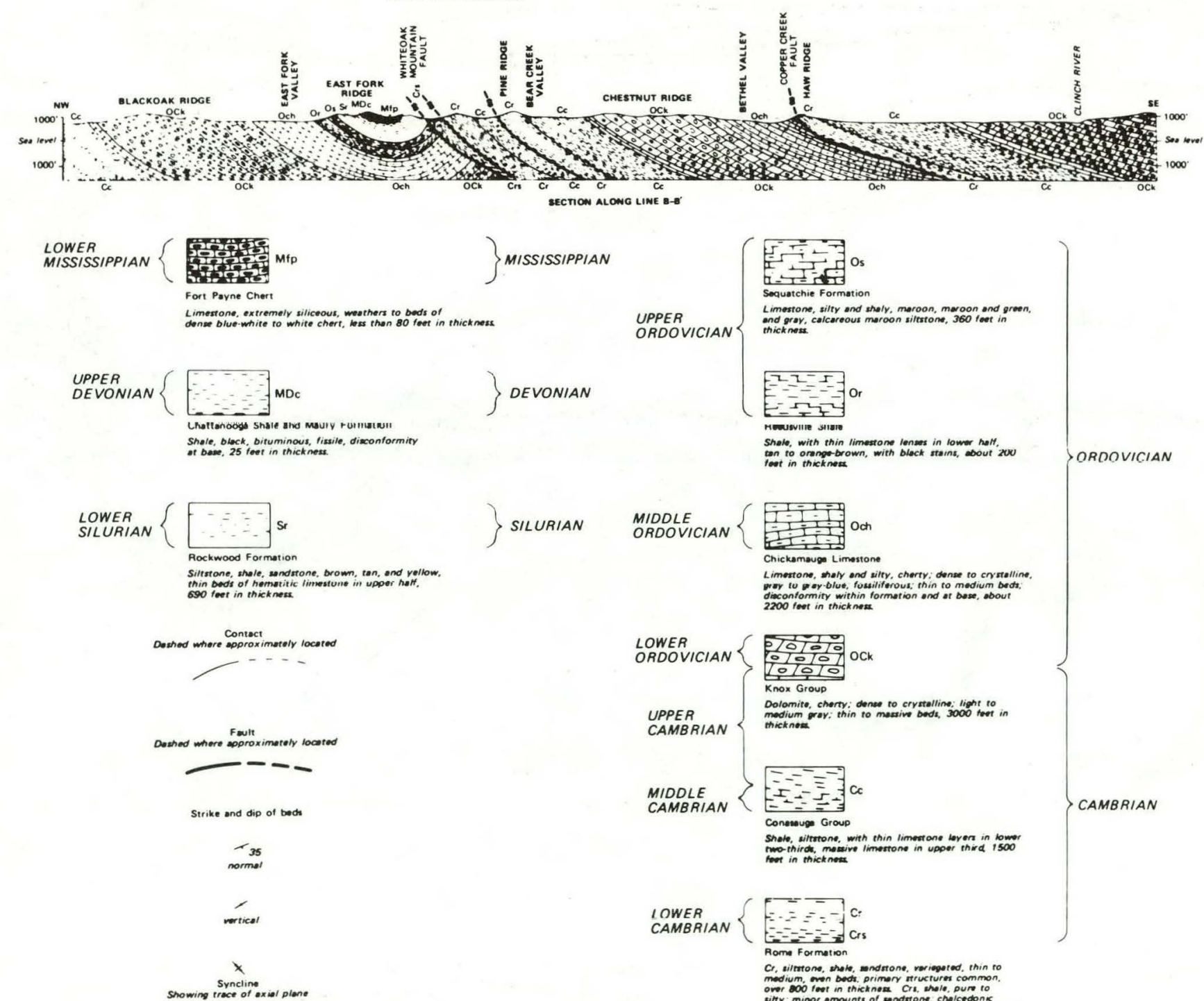

of VII (see Table 1). Moderately strong epicentral shaking (maximum inV) also occurred from local events in 1811-1812 were also observed in the Knoxville-0ak Ridge area during the ton, South Carolina, earthquake, although the epicenters of these large earthquakes were located over 280 miles $(450 \mathrm{~km})$ from 0ak Ridge. The geology and tectonic structures in both the New Madrid and Charleston
areas are completely unrelated to the structure in the Southern Appalachians.

AGRICULTURE AND FOREST RESOURCES

Agricultural Productivity Potential

Suitability of land for use in forestry and agriculture is based mainly on soil characteristics. Soils of the Reservation differ widely in productivity. Agronomy is practiced intensively on only part of the forests also possess varying potential for agricultural productivity. The potential for productivity is based on a survey of physical and chemical characteristics of soil and on topographic and conservation features of the landscape. The most significant characteristics considered are depth, texture, structure, organic matter, fertility, reaction, are comonly ranked into five classes with first-class soils being most productive and fifth-class soils being least productive ${ }^{4}$

1. First-class (I) soils are very productive, easily worked, and possess simple problems with conservation.

2. Sernnd-rlass (IT) snils are moderately productive, less work-

3. able, with more conservation problems than for Class I with greater conservation problems. Intense management prac-

4. tices are required, and growth of field crops is impractical.
Fourth-class (IV) soils are not suitable for growth of crops,

but may be moderately productive for pasture.

th-class (V) soils are not suitable for crops or pasture; forestry is best use of the land.

Soil classes provide the basis for summarizing land-use potentia for agricultural purposes. The main categories of land types are:

Type 1. Land is characterized by favorable productivity, workability, and minimum problems of conservation; land consists of soi the 0ak Ridge Reservation qualifies as land type 1 (Map 2). ${ }^{4}$ M. E. Swann et a7 , Soil Survey of Roane County, Tennessee, USDA Document 
Table 1. Predicted Site Seismic Characteristics

\footnotetext{
Maximum earthquake

Peak acceleration, \% g 15 Intensity $(\mathrm{MM})^{\mathrm{a}}$

Richter magnitudeb

VI-VII I

4.7

Design earthquake

Peak acceleration, \% g 6 Intensity (MM)a V-VII

Richter magnitudeb $\quad 3.0$

aModified Mercalli intensity dependent on foundation condition.

bWill produce accelerations near the epicenter approximating those yiven.
} 
ORNL-DWG 75-6036

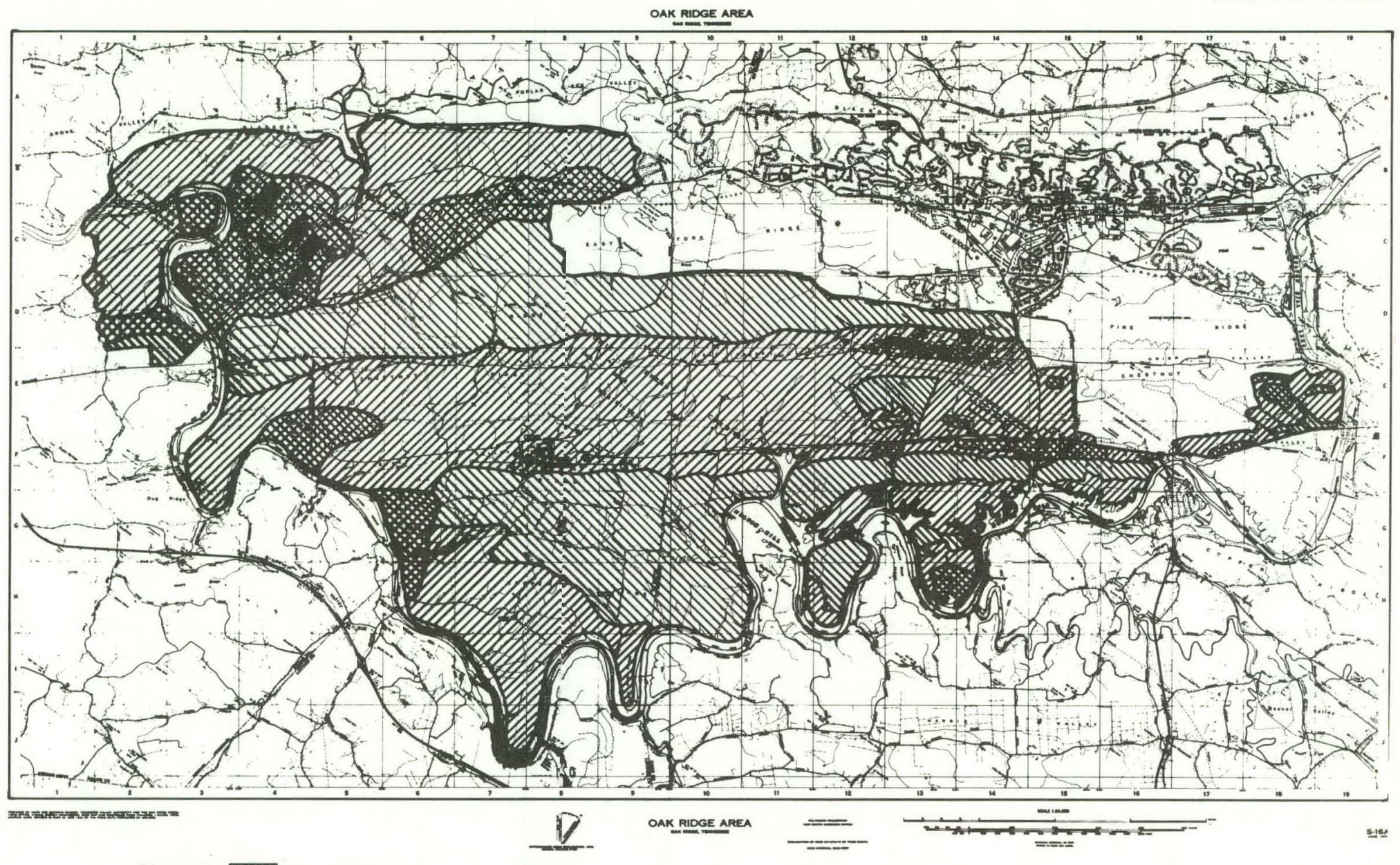

Type 1

Type 2 VIII

Type 3 जाञ

Map 2. Land-type suitability for agriculture. 
Type 2. Land is characterized by moderate productivity but possesses unfavorable workability; frequent problems with conservation are encountered; land consists of soil class IV. Approximately $20 \%$ of the reservation 1 and is type 2 (Map 2).

Type 3. Land is not suitable for agriculture; land is best suited for forest management; land consists of soil class $\mathrm{V}$. Approximately $50 \%$ of the reservation is type 3 (Map 2).

The land-type categories identify areas on the reservation possessing varying potential for food and fiber production. Priority consideration is given to minimizing the future irreversible commitment of the resources needed for food production, specifically type 1 land consisting of soil classes I, II, and III.

\section{Forestry}

The vast majority of the lands of the 0ak Ridge Reservation are utilized for forestry. The purpose of the forest management program is to optimize yield of high quality forest products in a manner which is compatible with plant operations, environmental research programs, and other aspects of the ERDA mission at 0ak Ridge. Forest management also contributes to the overall Oak Ridge-ERDA Program, in particular the environmental research programs, specifically by providing for disease control, prevention and suppression of wild-fire, and for disposing of timber from construction sites and rights-of-way. Through coordination of commercial forestry activities with environmental research programs, special ecological conditions can be created for experimental use.

Timber sales contribute to the employment of the region through both harvest and wood-product manufacture. It is important to recognize that over the near-term period, all maturing trees in designated compartments (Map 3) are committed to harvest and management for sustained yield in order to meet contractual requirements. Compartment numbers are keyed to the 1970-75 Forest Management Plan. ${ }^{5}$ For each compartment, summary statistics (as of 1970) on forested research areas and other categories and timber volume and composition are included.

\section{Silvicultural Management Practices}

Development of the optimum species composition for each site is the over-all silvicultural aim of the forestry management program. To accomplish this objective, a combination of several silvicultural systems is

\footnotetext{
${ }^{5}$ W. G. Strock, Jr., Forest Management Plan, AEC Oak Ridge Reservation: 1970-75, USAEC Report ORNL/TM-3175, Oak Ridge National Laboratory, 1970.
} 
ORNL-DWG 75-6035

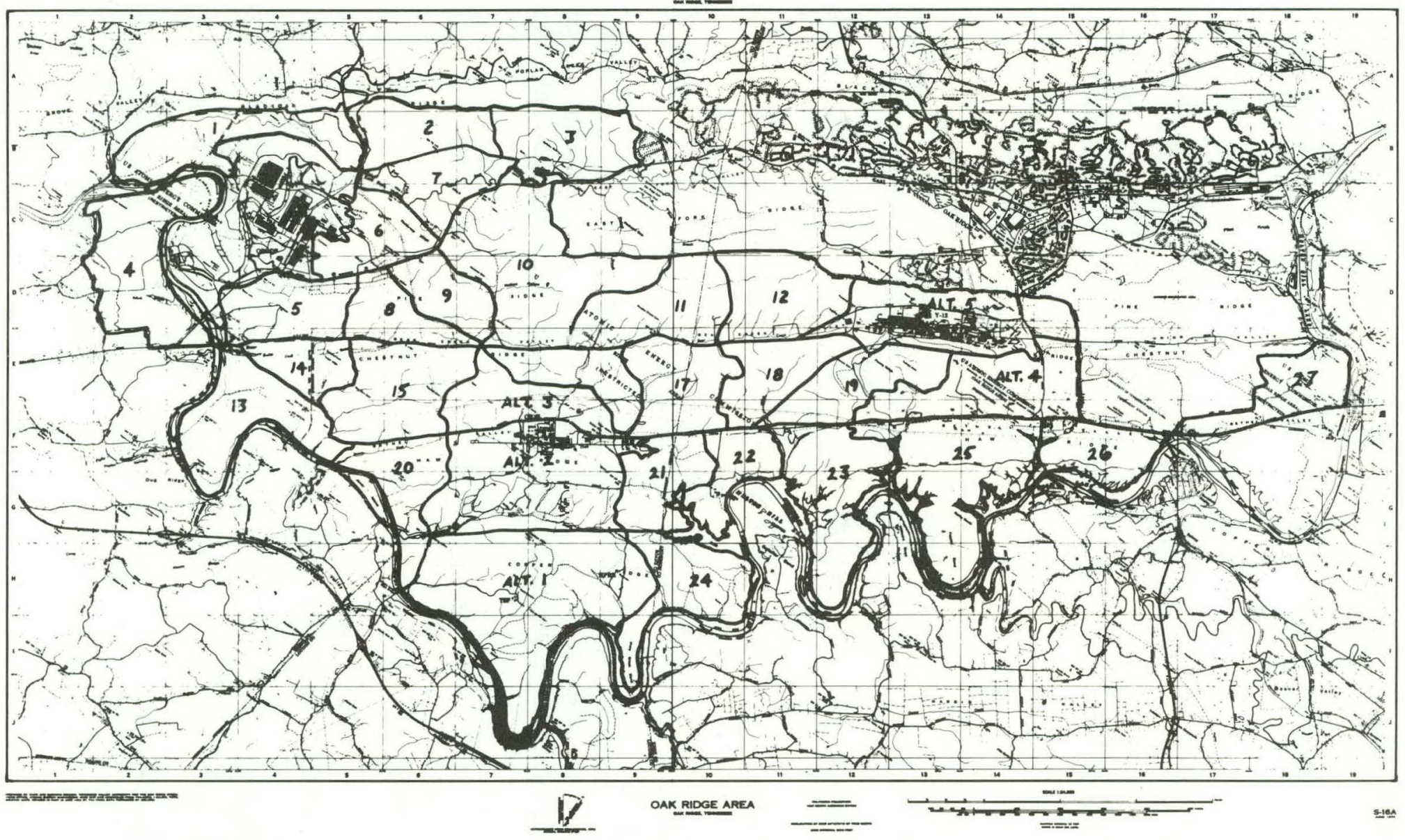

Map 3. Forestry compartments. 
used-- the choice depending on the production capabilities of the forest site in question. The more productive sites produce mature timber earlier and can support greater sawtimber volume than poorer sites; timber value is generally greater on good sites; hence one can afford to invest more on silvicultural improvement of such areas. Management practices for typical sites found on the reservation are described as follows:

Ridges, upper slopes, south mid-slopes, and other lowproductivity sites. These areas range in oak site index from 40 to 60 . Such sites generally occupy dry rocky or cherty ridges, upper slopes, and mid-s lopes facing south (topographic classes 1,2, and 3; Fig. 1 of Strock ${ }^{5}$ ) and small areas of severely eroded soil. Less desirable oak species, Virginia pine (P. virginiana Mill) and shortleaf pine ( $P$ : echinata Mill) usually predominate. Yellow poplar (Liriodendron tülipifera L.) outgrows most oaks on the "better" poor sites but will not form pure stands. The proportion of yellow poplar can be increased with proper management. Virginia pine is best suited for the poorest sites and is favored where present. On the poorest sites the objective is simply to maintain soil cover because timber production is economically marginal. For instance, narrow bands of Bland soil, a highly erodable soil formed over calcareous siltstone, run eastwest across the reservation and are suited only for eastern red cedar (Juniperus virginiana L.) and undesirable oaks.

Sites of low productivity are primarily managed by the single tree selection system which results in an uneven-aged forest. The better species will be favored and selection is aimed at improving over-all timber quality. This silvicultural system will tend to perpetuate the shade-tolerant species of oak and offer maximum protection to the sites through complete canopy cover. Where pine predominates and is suited to the site, a 40- to 50-year rotation will be established. Hardwoods intended for sawlogs will require a 90- to 120-year rotation. The upper d.b.h. ${ }^{7}$ limit for sawtimber is 16 to $18 \mathrm{in.}$ (41 to $46 \mathrm{~cm}$.) on these siles and w11l be cut on reaching this size.

Coves, lower slopes, north slopes, and valley sites. These generally range in oak site index from 60 to 80 . Such sites occupy coves, minor bottoms, north slopes, and many of the lower south slopes (topographic classes 4 through 8, Fig. 1 of Strock ${ }^{5}$ ). Some broad ridges with relatively deep, well-drained soil developed from 1 imestone parent material are included in this site class.

${ }^{6}$ Site index is a measure of the capability of land to produce timber. It is the height in feet that trees will attain in 50 years.

${ }^{7}$ Diameter breast height; i.e., diameter of the tree trunk at $1.4 \mathrm{~m}$ above ground. 
Many sites of this type can support pure stands of yellow poplar, and on the better cove sites black walnut (Juglans nigra L.) and northern red oak (Q. rubra L.) do well. The silviculture practice is to increase the proportion of yellow poplar on the more productive sites. White oak (Q. allba L.) is favored on the midslopes and some upper north slopes.

Even-aged silviculture is used to manage the productive sites. This method tends to increase the proportion of shadeintolerant species such as yellow poplar. Two distinct phases make up the rotation; reproduction-harvest and intermediate cutting.

The reproduction cut is made the final year of the rotation, usually in a mature stand, al though understocked stands or those composed of undesirable species can be cut before maturity in order to regenerate the area with suitable growing stock. The reproduction cut removes all mature timber and prepares the area for regeneration by advanced reproduction, by seed lying dormant on the forest floor, or by seed fall from surrounding trees. All cull sawtimber or non-merchantable trees are removed for pulpwood or deadened after the reproduction cut to assure successful regeneration.

Intermediate thinnings and improvement cuts are made each 12 years, beginning the second management cycle after regeneration. Over-all timber quality is improved by removing the poorest trees and the less desirable species. Intermediate cuts also maintain proper spacing and stocking in the interim between regeneration and the harvest cut. Initial thinnings and improvement cuts will only yield pulpwood. As the trees grow, sawtimber can also be removed, leaving the best trees as crop trees. Reproduction is of no concern during the intermediate stages of rotation. Thinning and improvement cuts are normally terminated after the first 60 to 70 years.

The very best cove and minor bottom sites can produce 24to 28-in. sawtimber with a 60- to 75-year rotation. Slope sites of intermediate productivity will produce 20 - to $24-i n$. (51 to $61 \mathrm{~cm}$.) sawtimber with a rotation of 75 to 90 years given proper thinning and care.

Plantation Sites. Plantations of pine occur on old field sites in the valleys and on lower slopes. The trees were planted on a nominal 6- $x$ 6-ft spacing and survival was generally good. The oldest of the pine plantations is now 20 years old.

A commercial thinning program was begun in 1967 on the oldest and most heavily stocked stands. Approximately onehalf of the 1740 ha of plantations have now been thinned. An income of $\$ 45,000$ has been realized from the sale of 10,544 cords of pine pulpwood from these thinnings. 
A few stands remain unthinned as controls to be used in making comparisons with stands of similar size and stocking that were thinned. The effectiveness of the thinning program is apparent from comparisons of some of the earlier thinned stands with the control stands. White pine pulpwood is not used by the local papermills; thus commercial intermediate thinnings cannot be made on the comparativeily small acreage planted to this species.

Planted areas perpetually managed for pine will be operated on an even-aged rotation of 40 years for shortleaf pine and 60 years for loblolly pine. Seed tree regeneration cuts at rotation age will leave 15 to 20 trees per acre to provide seed for the next generation. After reproduction has been established, the seed trees will be harvested. Areas where natural regeneration is not satisfactory will be planted and acres where hardwoods are more desirous will be converted and managed according to silvicultural policies outlined earlier for comparable site classes.

Special Programs

Forestry Management maintains sufficient flexibility in phasing of near-term operations to provide special management treatments. The periodic outbreaks of the southern pine beetle (Dendroctonus frontalis), for example, have required special types of management operations during the past several years. These operations include rapid implementation of disease control measures (e.g., spot cutting, clearing, and slash removal); salvage of merchantable, beetle-infested timber; and forest stand regeneration. Management of forest stand regeneration takes account of present and potential research needs for diverse habitat types and optimal species selection for specific site conditions. Another management practice is the removal of cull trees, thereby improving stand quality. Cull trees have very little, if any, value and also compete with the better growing stock for area, moisture, and nutrients. Cull trees not removed during a harvest cut will be killed by suitable methods. An area of approximately 1210 ha also needs adjustment in species composition and general upgrading of timber quality.

\section{AQUATIC ENVIRONMENTS ON AND CONTIGUOUS TO THE OAK RIDGE RESERVATION}

The Oak Ridge-ERDA Reservation is in the lower portion of the Clinch River drainage basin which originates in southwestern Virginia and drains an area of approximately $11,430 \mathrm{~km}^{2}{ }^{2}$ The $\mathrm{Cl}$ inch River bounds the Reservation on the south and west for a length of approximately 39 miles $(63 \mathrm{~km}$.$) ,$ extending from Clinch River Mile (CRM) 49 on Melton Hill Reservoir to CRM 10.0 just downstream from the mouth of Poplar Creek (Map 4). Surface waters on and contiguous with the Reservation, including the Clinch River, are important resources for research, recreation, municipal and industrial activities in the 0ak Ridge area. The primary surface waters on the 


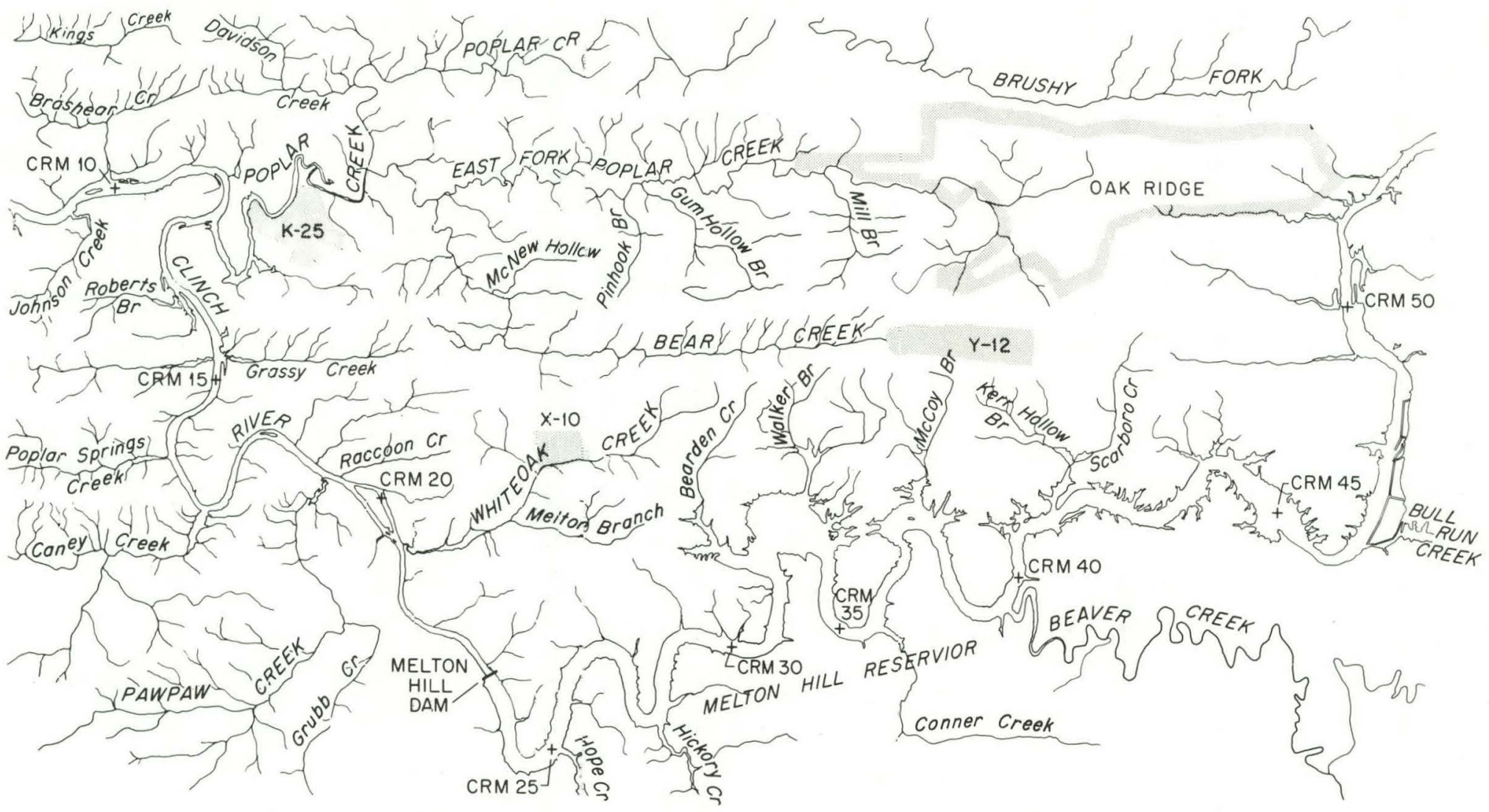

Map 4. Aquatic environments on and contiguous with the Oak Ridge - ERDA Reservation. 
Reservation proper are small streams which generally originate from contributing springs in the limestone on the ridge slopes. Average annual discharge rate of the small streams is less than $0.57 \mathrm{~m}^{3} \mathrm{sec}^{-1}$.

The groundwater table of the reservation can be described as a subdued replica of the surface topography. Thus the groundwater flows from areas of high elevation to areas of low elevation and ultimately discharges into surface streams. In general, this description may be extended to the entire reservation where groundwater occurs under water table conditions in a humid region.

Runoff Characteristics of Oak Ridge Catchment Basins

Storm runoff in the vicinity of 0ak Ridge has been described for a variety of catchment basins from 0.38 to $82 \mathrm{sq}$ miles $\left(1.0\right.$ to $\left.212 \mathrm{~km}^{2}\right)$ in area. ${ }^{8}$ Stream flow (Q) of Walker Branch was best described by the relationship $Q=1.9 \mathrm{p}^{2}$ where $Q$ has units of cubic feet per second and $P$ is precipitation in inches (1 to 9 in. per event). A slightly modified relationship $\left(Q=4.7 A^{0} \cdot{ }^{8} p^{2}\right.$, where $A$ is square miles) hol ds for other catchments of the Oak Ridge areas. It was estimated that a storm involving 9 in. of precipitation in $48 \mathrm{hr}$ (100-year recurrence interval) would generate 150 to $600 \mathrm{cfs}$ ( 4200 to 1700 liters $\mathrm{sec}^{-1}$ ) of discharge per square mile of catchment basin.

Water quality of surface streams on the Reservation is, in general, of the calcium-magnesium-bicarbonate type, reflecting the limestone geology of the area. Water quality and ecology of several of the streams on the Reservation, however, have been altered as a result of industrial and municipal effluents. The major drainage basins on and flowing through the 0ak Ridge Reservation are White Oak Creek with a drainage area of $16.9 \mathrm{~km}^{2}$ (Fig. 1) and Poplar Creek with a drainage area of $352 \mathrm{~km}^{2}$. Several smaller catchments on the Reservation with small, perennial streams which are aquatic research sites and control areas for environmental monitoring programs include Walker Branch (drainage area = $1 \mathrm{~km}^{2}$ ), McCoy Branch, Scarboro-Kerr Hollow $\left(3 \mathrm{~km}^{2}\right)$, and Grassy Creek $\left(3 \mathrm{~km}^{2}\right)$. In addition, there are two small quarries on the Reservation (Roger's Quarry and Lambert Quarry) that serve as experimental sites for aquatic research.

\section{Clinch River}

The Clinch River is the major source of water for industrial (cooling water, waste disposal, etc.), municipal (drinking water), and recreational use in the 0ak Ridge area. This river, an incised meandering type stream, provides trellis-type drainage of the Oak Ridge area. River flow in the

\footnotetext{
${ }^{8} \mathrm{~F}$. D. Sheppard. Storm runoff in the vicinity of Oak Ridge, Tennessee. ORNL/TM-4662. 1974.
} 


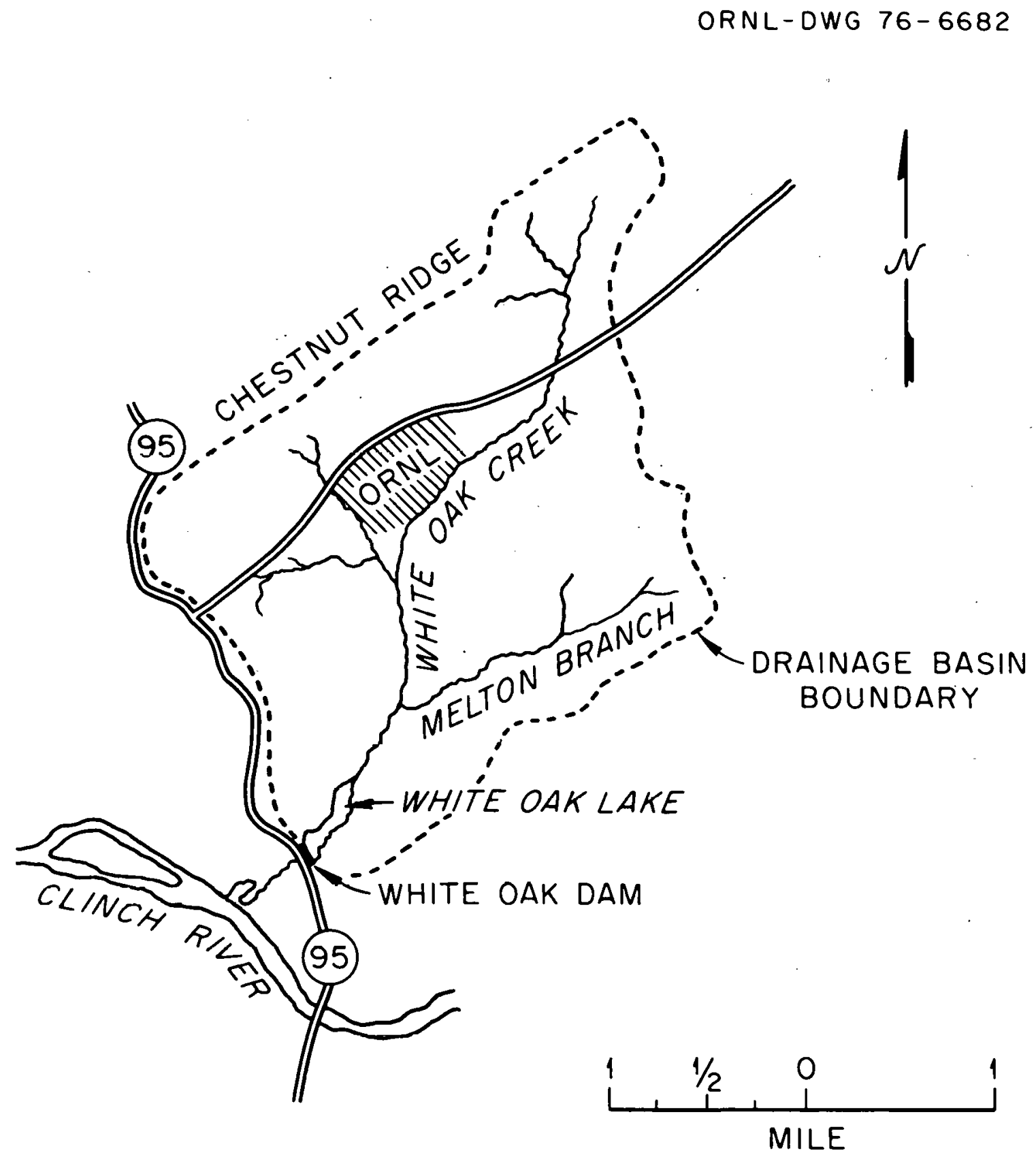

Fig. 1. White Oak Creek drainage. 
39-mile $(62.8 \mathrm{~km})$ stretch (CRM 49 to 10.0) along the south and west boundaries of the ERDA reservation is regulated principally at Melton Hill Dam (CRM 23.1). Melton Hill Reservoir extends approximately 43 miles (70 km) upstream (to CRM 67), with a shoreline of 143 miles (230 km), a surface area of 5718 acres (2375 ha), and a maximum width of $0.8 \mathrm{mile}(1.3 \mathrm{~km})$. Flow below the Melton Hill Dam since. 1963 has averaged 7800 cfs $(221,000$ liters $\left.\mathrm{sec}^{-1}\right)$. The maximum daily release was 26,900 cfs $(761,000$ liters $\sec ^{-1}$ ) on March 16, 1973. Since the closure of the dam in 1963, there has been an average of 46 days per year in which no water was released from Melton Hill Dam.

Water flow in the Clinch River below Melton Hill Dam is affected by the operation of Watts Bar Dam, located at TRM $529.9,38$ miles $(61.1 \mathrm{~km})$ downstream from the mouth of the Clinch River. Before construction of Melton Hill Dam, Watts Bar Reservoir extended upstream to CRM 28.

The Clinch River is a moderately turbid, hardwater system, but water quality generally complies with Tennessee State water quality standards. Sediment composition varies throughout the 39-mile stretch that bounds the Reservation, ranging from silt-clay and fine sand to coarse sand and gravel. With the impounding of the Clinch River at Melton Hill Dam, several embayments on Melton $\mathrm{Hill}$ Reservoir that receive runoff from the Reservation were formed (Fig. 2). Some of these embayments are relatively isolated water bodies even though they are connected to Melton Hill Reservoir.

\section{Bearden Creek Embayment}

Bearden Creek Embayment located at CRM 32, is the largest (surface area $=47.9 \mathrm{ha})$ of the four embayments on Melton Hill Reservoir that bound the Reservation (Fig, 2). This embayment receives flow from Bearden Creek, a small stream that drains a small oak-hickory watershed on Chestnut Ridge. Although no environmental sampling has been conducted in this embayment, it is expected that the water quality and biota are similar to that in walker Branch embayment which receives drainage from a catchment with the same geology and land use.

\section{Walker Branch Embayment}

The Walker Branch Embayment has a surface area of approximately $9.6 \mathrm{ha}$ and a volume of $6.5 \times 10^{5} \mathrm{~m}^{3}$. It receives runoff from five small intermittent streams, including the combined forks of Walker Branch (Fig. 3). Although the embayment is turbid in certain near-shore areas subject to ernsion and resuspension of sediment from wave action, water transparency is relatively high in open water areas. This is evidenced by the fact that the depth at which the amount of solar radiation at the water surface is reduced to $1 \%$ has been found to exceed $5 \mathrm{~m}$ in open water areas of the embayment during the summer. Primary production rates in this embayment appear to be relatively high as indicated by chlorophyll concentrations ranging from 5 to $7 \mathrm{\mu g}^{1} \mathrm{iter}^{-1}$ in samples collected from 

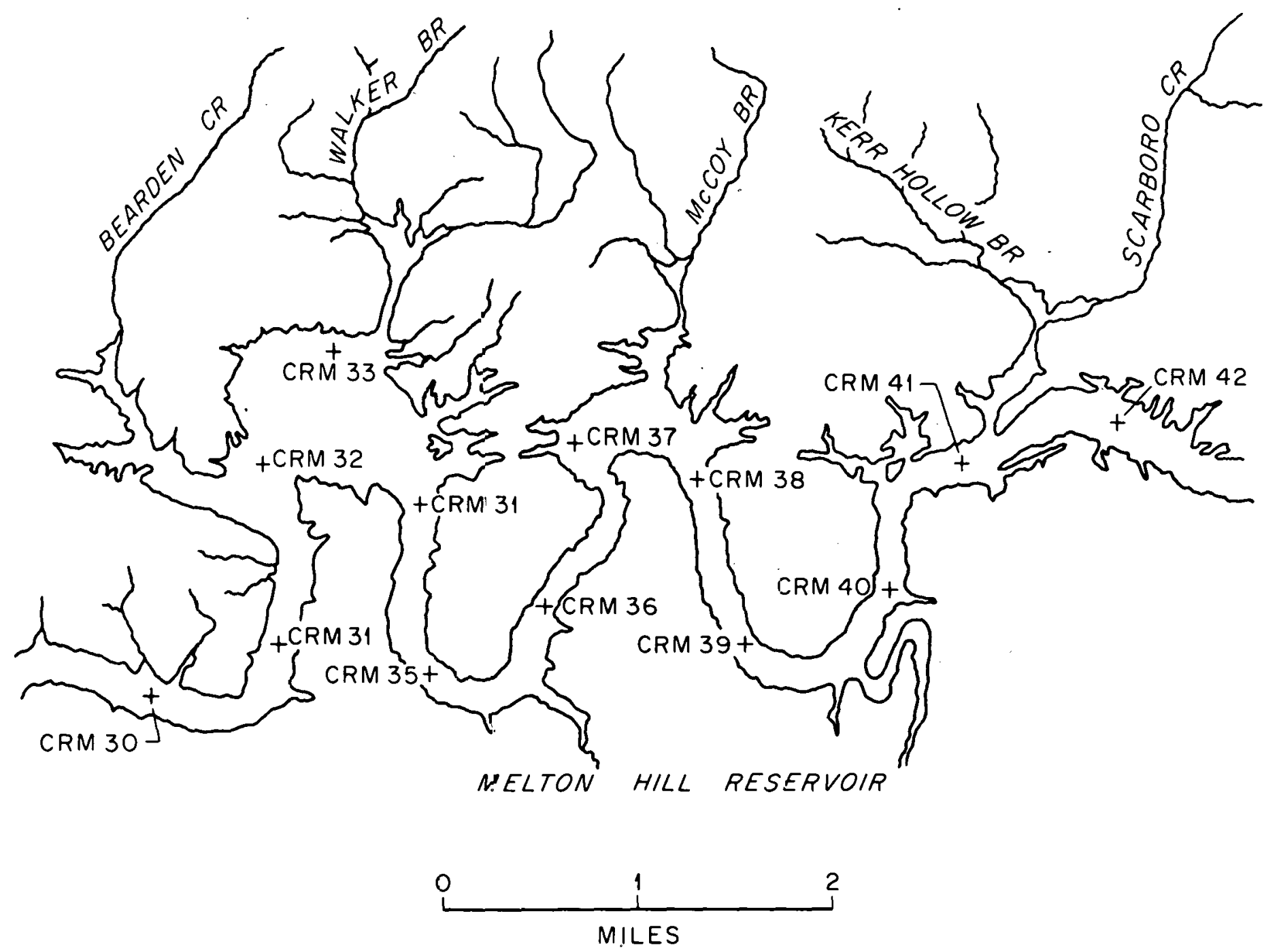

Fig. 2. Portion of Melton Hill Reservoir with four embayments bounding the Oak Ridge ERDA Reservation. Embayments are associated with Bearden Creek, Walker Branch, McCoy Branch and Kerr-Hollow Branch. 


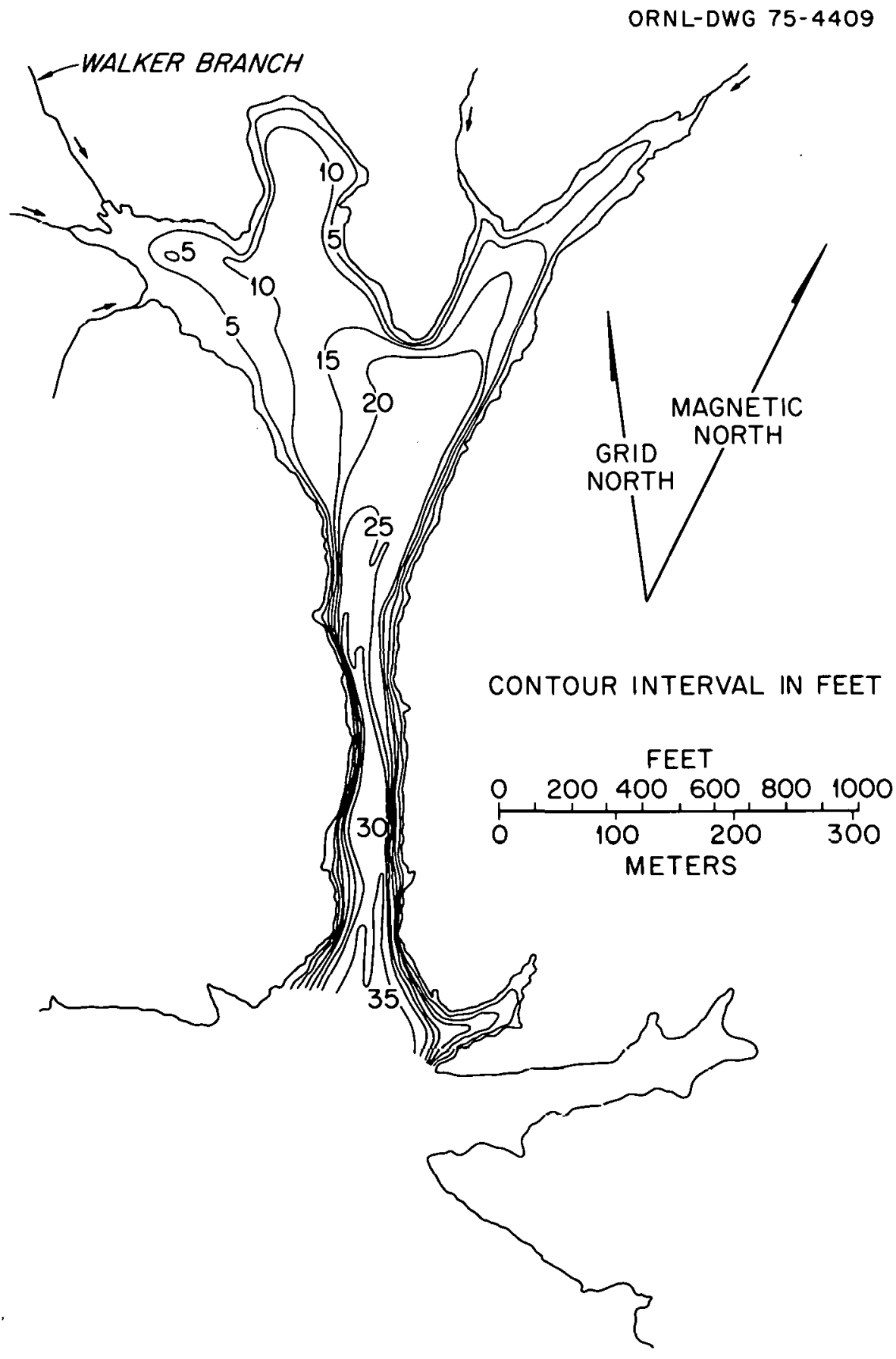

Fig. 3. Walker Branch Embayment, Melton Hill Lake, Tennessee. 
0 - to 6-m depth. These chlorophyll concentrations are comparable to those in mesotrophic lakes.

A slight thermal stratification occurs in the embayment during the summer with the top of the thermocline in August at 3-m depth and approximately $1-\mathrm{m}$ thickness. The stability of the thermal stratification in this embayment in relation to water level fluctuations and wind action is unknown.

Sediments in the deeper areas of the embayment are dominated by particles less than $53 \mu \mathrm{m}$. Surface sediments consist of a flocculant silt-clay mixture and indicate that significant scouring of surface sediments is not occurring as a result of oscillatory water exchanges with the main channel of Melton Hill Reservoir. The organic content of sediments throughout the embayment is relatively uniform except at the mouth of streams. In open water areas, the organic content averages approximately $7 \%$, whereas at the mouth of some streams, organic content in sediment samples exceeds $15 \%$. This higher organic content at mouth of inflowing streams reflects the inputs of organic leaf detritus from streams draining the deciduous forest watersheds that surround this embayment.

The average density of benthic macro-invertebrates in Walker Branch embayment in June was found to be approximately 200 organisms $\mathrm{ml}^{-1}$. In terms of numbers, the benthos is dominated by Chironomidae followed by Hexagenia sp. (Ephemeroptera), and 01igochaeta. The standing crop of benthos biomass is dominated by Hexagenia sp. with a mean of $1.6 \mathrm{~g} \mathrm{~m}^{-2}$ (wet weight), followed by the Chironomidae $\left(0.4 \mathrm{~g} \mathrm{~m}^{-1}\right)$ and 01 igochaeta $\left(0.04 \mathrm{~g} \mathrm{~m}^{-2}\right)$.

McCoy Branch Embayment

McCoy Branch embayment (18.8 ha) is formed by Melton Hill Reservoir at CRM 37.4 (Fig. 2). McCoy embayment receives flow from McCoy Branch from the northeast and an unnamed tributary from the northwest. McCoy embayment runs through a gap in Haw Ridge and is separated from the reservoir proper by a highway fill with two $4.6 \mathrm{ft}(1.4 \mathrm{~m})$ diameter culverts. Depth in the embayment is approximately $9.8 \mathrm{ft}(3 \mathrm{~m})$. The land surrounding McCoy embayment is forested except for pastures in Bethel Valley to the north (Fig. 2).

McCoy Branch receives inputs from the fly-ash disposal pond on Chestnut Ridge, and fly ash is present in the sediments of the McCoy Branch embayment. The impact of this fly-ash drainage on the embayment - is unknown. The McCoy Branch embayment system does represent a unique study area in which to investigate the impacts on an aquatic ecosystem of fly ash from coal combustion. Two species of benthic invertebrates (Hexagenia sp. and Chironomus sp.) were collected from this embayment in october 1974. Bluegill, white crappie, and carp were the dominant fish species collected by electrofishing. 
Scarboro Embàyment

Scarboro embayment, formed by Melton Hill Reservoir at CRM 41.2 (Fig. 2), is about $0.6(1 \mathrm{~km})$ 1ong, with an average width of $328 \mathrm{ft}$ $(100 \mathrm{~m})$. It lies roughly parallel to Haw Ridge in Bethel Valley and is separated from the reservoir proper by a highway fill with two 4.6-ft $(1.4-m)-d i a m$ culverts. North of Haw Ridge the embayment is further divided, forming east and west arms that are connected by a culvert.

The east arm of Scarboro embayment is bordered on the north by the Comparative Animal Research Laboratory (CARL), which consists of a complex of research and livestock-holding facilities. The slope toward this embayment of surrounding fields of this area is less than $5 \%$. Haw Ridge, forested by second-growth deciduous trees, borders the south shore of Scarboro embayment. The east arm of Scarboro embayment has a maximum depth of $6.6 \mathrm{ft}(2 \mathrm{~m})$. Scarboro Creek flows into the east arm of Scarboro embayment from a north-northeast direction.

The west arm of Scarboro embayment is bordered by pasture on the north and west and by Haw Ridge on the south. Land use, slopes, water depth, and bottom sediments are similar to those reported for the east arm. Kerr Hollow Branch flows into the western portion of this embayment from a northwest direction. The agricultural runoff into this embayment from the UT-CARL farm provides contrasting inputs which allows comparative studies with other embayments in the area receiving inputs from drainages with different 1 and and water uses. Sediments in the Scarboro embayment are dominated by silt-clay particle sizes.

Although only limited biological sampling has been conducted in this embayment, the benthic fauna appears to be typical of other embayments in this area of Melton Hill and is dominated by species of Chironomidae and Tubificidae. Bluegill, carp, white crappie, gizzard shad, and threadfin shad were the dominant fish species collected. Fish collections suggest that threadfin shad use the east arm of Scarboro embayment as a spawning and nursery area. Macrophytes present include cattails (Typha latifolia) and milfoil (Myriophyllum sp.).

White Oak Creek Drainage

White Oak Creek basin has an area of 6.53 square miles $\left(16.9 \mathrm{~km}^{2}\right)$ (Fig. 1). The headwaters of White Oak Creek originate on the forested slopes of Chestnut Ridge, north of ORNL. Numerous springs intersecting with lie upper reaches of White Oak Creek provide a relatively stenothermic aquatic environment. Stream width varies from 2.0 to $4.0 \mathrm{ft}$ $(0.6$ to $1.2 \mathrm{~m})$, and depth, from 3.9 to $9.8 \mathrm{in}$. $(10$ to $25 \mathrm{~cm})$. Stream bed substrate is predominantly rocks of 2.0 to $3.2 \mathrm{in}$. $(5$ to $8 \mathrm{~cm})$ diameter with some exposed bedrock.

Because most of the basin is underlain by the Rome formation and Conasauga group, the base-flow discharge of White 0ak Creek is low, and, during intervals of low rainfall, no natural flow occurs. The bẹt of 
Knox dolomite underlying Chestnut Ridge, which forms the northwestern drainage divide of the basin, is the principal water-bearing formation. Several springs along the base and in the Ridge valleys are tributaries to White Oak Creek. Ninety percent of the White Oak Creek dry-weather discharge originates as groundwater discharge from the Knox dolomite of Chestnut Ridge, the Chickamauga limestone of Bethel Valley, and ORNL plant effluent.

Approximately $1.55 \mathrm{miles}(2.5 \mathrm{~km})$ from the source, White 0ak Creek enters the confines of ORNL in Bethel Valley. A substantial part of the flow in White Oak Creek is waste water from ORNL. Gravel substrate predominates. The Melton Branch tributary of White 0ak Creek drains 1.48 square miles $\left(3.83 \mathrm{~km}^{2}\right)$ in Melton Valley and enters White Oak Creek 1.55 miles $(2.5 \mathrm{~km})$ above the Clinch River (Fig. 2). Melton Branch bottom is mainly gravel. Both streams receive liquid effluents from ORNL operations and leachates from solid and liquid radioactivewaste disposal areas in the drainage basin. Species composition of biota in the lower portions of both streams has been altered significantly as a result of these effluents. Levels of constituents in the discharge are monitored, and relationships to state and federal standards are reported annually. ${ }^{9}$

Before converging with the CTinch River (CRM 20.8), White Oak Creek flows into White Oak Lake, a 20-acre (8-ha) impoundment formed in 1943. White Oak Lake serves as the final settling basin for ORNL waste management and can be characterized as a eutrophic lake. Bottom sediments are primarily silt and clay. Water from White 0ak Lake discharges through a weir at White Oak Dam at an average flow rate of 15 cfs (425 liters $\mathrm{sec}^{-1}$ ) $80 \%$ of the time. The creek meanders for approximately $0.6 \mathrm{mile}(1 \mathrm{~km})$ and empties directly into the $\mathrm{Clinch}$ River. Gravel and clay-mud substrates are the predominate bottom material in White 0ak Creek below the dam.

Poplar Creek Drainage Basin

Poplar Creek with a drainage area of $136 \mathrm{mi}^{2}\left(352 \mathrm{~km}^{2}\right)$ is the largest stream flowing into the $\mathrm{Cl}$ inch River from the Oak Ridge Reservation. There are three main tributaries in the Poplar Creek drainage--the main branch of Poplar Creek, East Fork Poplar Creek, and Bear Creek. Poplar Creek enters the Reservation north of the Oak Ridge Gaseous Diffusion Plant (ORGDP), meanders for about 6.3 miles $(10 \mathrm{~km})$ through the plant area, and enters the Clinch River at CRM 12. East Fork Poplar Creek passes through the Reservation for about 4.5 miles $(7.2 \mathrm{~km})$ and enters Poplar Creek northeast of the ORGDP. Bear Creek flows in a southwest direction from the $Y-12$ Plant to white Wing Road (State Highway 95) through second-growth hardwood forests and late-successional old fields. At White Wing Road, Bear Creek turns

${ }^{9}$ Environmental Monitoring Report, United States Energy Research and Deve1opment Administration, Oak Ridge Facilities. UCC-ND-302, 51 pp., 1974. 
northwest for the final 2 miles $(3.2 \mathrm{~km})$ of the approximately $7-\mathrm{mile}$ (11.3-km) course, converging with East Fork Poplar Creek at mile 1.5.

\section{Poplar Creek}

Poplar Creek flows generally southwest for $24.8 \mathrm{miles}(40 \mathrm{~km})$ from the Cumberland Mountain section of the Appalachian Plateau province, through the Valley and Ridge province around Oak Ridge, to the Clinch River (at CRM 12.0). About 65\% of the total basin is wooded, and the remainder is largely farmland. Coal mining, principally by the stripping method, is extensive in the Cumberland Mountain part of Poplar Creek basin. The headwaters are adversely affected in many areas because of acid mine drainage. Undetermined amounts of domestic sewage from several small communities in the Upper Poplar Creek basin are discharged into the stream. The largest development in the basin is 0liver Springs, which has a population of about 1200 .

Poplar Creek, upon entering the ERDA Oak Ridge Reservation, is characteristically turbid. The stream averages $49.2 \mathrm{ft}(15 \mathrm{~m})$ in width and $9.8 \mathrm{ft}(3 \mathrm{~m})$ in depth. Watts Bar Dam at TRM 579.9 backs up water in Poplar Creek to Poplar Creek Mile (PCM) 3.5. Stream substrate consists of a mud-clay mixture. Bottom substrates vary with the fluctuations in Watts Bar Reservoir water storage. Principal substrates are large sandto gravel-sized coal grains.

\section{East Fork Poplar Creek}

East Fork Poplar Creek meets Poplar Creek at mile 5.5 (Fig. 4). Most of Poplar Oreek basin is underlain by shale and sandstone of low water-bearing capacity. Knox dolomite, which outcrops mostly in the southeastern part of the basin, occupies only about $5 \%$ of the basin surface area but is the source of all large springs in the basin. The headwaters of East Fork Poplar Creek originate on the northwestern slopes of Chestnut Ridge in the vicinity of the Y-12 Plant. Streamflow is controlled by New Hope Pond, approximately 0.5 acre $(0.2$ ha), which serves as a settling basin on the east side of the $Y-12$. Plant.

East Fork Poplar Creek below New Hope Pond flows northeasterly from the $Y-12$ plant area for $0.3 \mathrm{mile}(0.5 \mathrm{~km})$ and is confined by $8-\mathrm{ft}(2.4-\mathrm{m})$ high riprapped streambanks of limestone rock. Stream substrate also consists of limestone rocks with some interspersed gravel. The pool immediately downstream from the dam averages about $15 \mathrm{ft}(4.6 \mathrm{~m})$ in width and $3 \mathrm{ft}(0.9 \mathrm{~m})$ in depth. Pools and riffles alternate, with a maximum depth in the pools of about $2 \mathrm{ft}(0.6 \mathrm{~m})$. Stream width varies from 10 to $15 \mathrm{ft}(3$ to $4.6 \mathrm{~m})$.

East Fork Poplar Creek, after leaving the Y-12 Plant area, flows northwest through densely forested secondary-growth hardwoods. The predominant substrate is $1-$ to $4-i n .(2.5-$ to $10.2-\mathrm{cm})$ rocks. Stream width varies from 10 to $25 \mathrm{ft}(3$ to $7.6 \mathrm{~m})$. Average stream gradient is about $21 \mathrm{ft} \mathrm{mile} \mathrm{m}^{-1}\left(4 \mathrm{~m} \mathrm{~km}^{-1}\right)$. At the Uak Ridge Turnpike (State Highway 95), East Fork Poplar Creek turns southwest and passes through several large 
ORNL-DWG $76-6681$
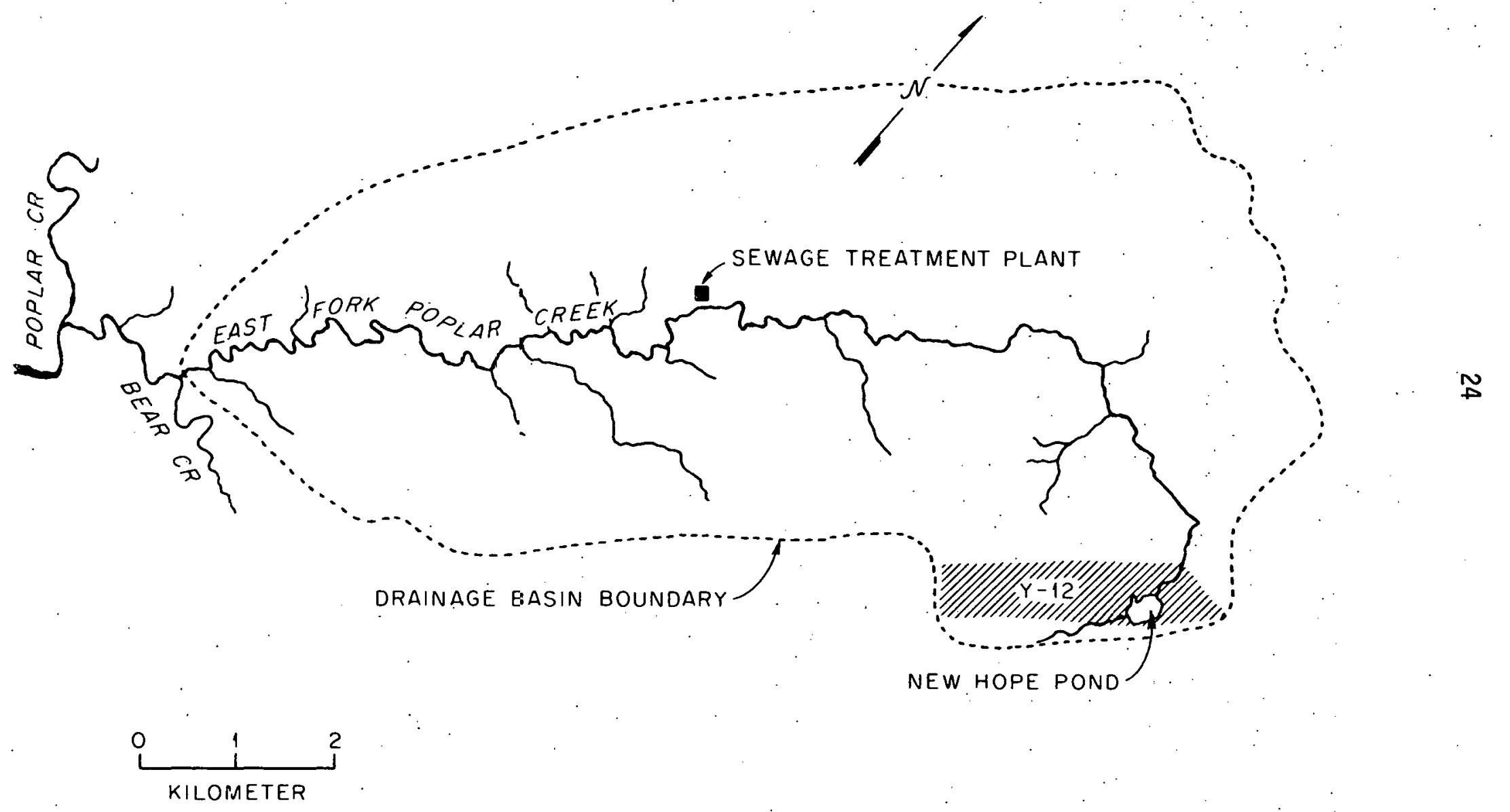

Fig. 4. East Fork Poplar Creek drainage. 


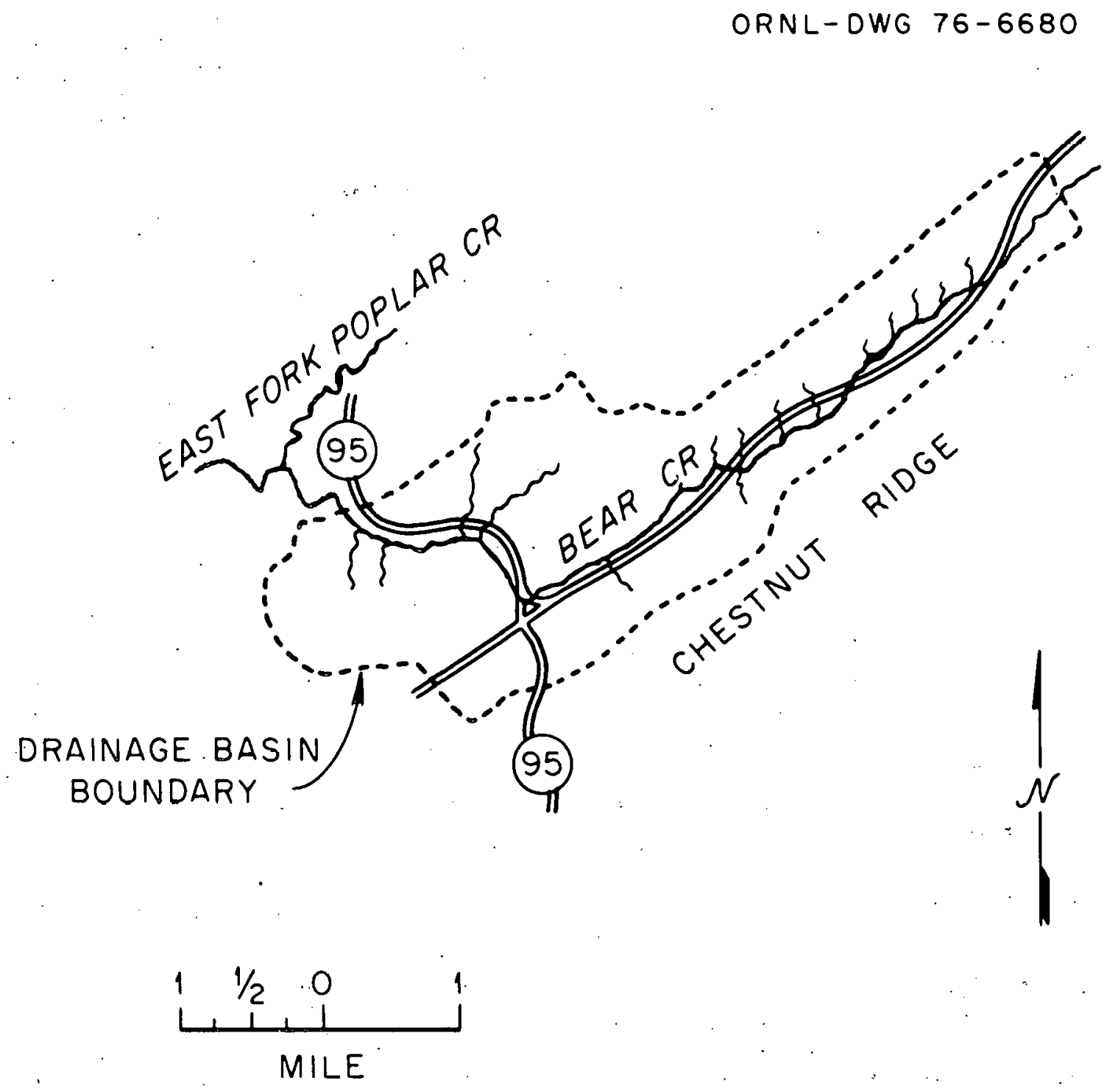

Fig. 5. Bear Creek drainage. 
pastures before entering hardwood forests. The 0ak Ridge sewage-treatment plant (west) is located on EFPCM 8.5. Substrates above the sewagetreatment plant are primarily gravel.

\section{Bear Creek}

Bear Creek basin has a drainage area of 7.4 square miles $\left(18.3 \mathrm{~km}^{2}\right)$ (Fig. 5). About $65 \%$ of the basin is wooded; the open land is mostly old fields. Several small perennial springs flow into Bear Creek from the 7 imestone beds in the upper part of the Conasauga formation and knox dolomite in Bear Creek Valley. The Rome formation occurs in the northern part of Bear Creek Valley. Residual soils in the valley consist of silt, sand, and coarse-textured material with small amounts of micaceous clay.

Stream habitat varies little as Bear Creek flows through Bear. Creek Valley. The narrow stream flows over clay and rock substrate covered by precipitates and a floc of aluminum hydroxide. The natural water flow in Bear Creek is augmented by discharges of $Y-12$ industrial waste water and seepages from $Y-12$ acid settling ponds and sanitary landfills. Stream width from $Y-12$ to the mouth of Bear Creek increases from 3 to 15 ft $(0.9$ to $4.6 \mathrm{~m})$, and depth, from $4 \mathrm{in}$. to $3 \mathrm{ft}(0.1$ to $0.9 \mathrm{iil})$.

\section{VEGETATION RESOURCES OF THE OAK RIDGE RESERVATION}

The vegetation of a region frequently is used as the prime interpretative measure of ecosystem and physiographic landscape units. Native plant communities often are a manifestation of combined environmental influences; i.e., solar radiation, precipitation, geology, soils, slope, and aspect. Plant communities also reflect management and biotic influences. Because natural ecological units of landscapes are strongly affected by vegetation, the character and composition of vegetation are valuable research resources, and they determine research opportunities and management policies.

The ecosystem approach to 1 and management is based on natural vegetation. Moreover, vegetation is an indicator of geologic, pedologic, topoclimatic, and hydrologic characteristics. Regional plant communities are important because they ameliorate air, noise, and water pollution; they control erosion and sedimentation; and they determine the aes thetics of the landscape. Furthermore, the distribution of plant types is a major factor in hazard mapping (such as fire potential and radicnuclide or pollutant distribution) and is basic to determining and managing wildlife habitat.

A preliminary synthesis of the vegetation (colored map), includes eight categories: Pine, Hemlock and/or White Pine, Cedar, Bottomland, Upland, and Northern Hardwoods, Nonforest, and Water. Although the mapping does not provide the amount of detail that either larger scales or differing 
conceptual interpretations might, it is believed that the result is a valuable and extremely useful tool for planning and use of facilities for programmatic research, and ancillary activities on the Oak Ridge Reservation.

Flora of the Oak Ridge area have been inventoried according to 14 habitat and 51 ife-form and 5 geographical locations. ${ }^{10}$ Most of the 1370 species listed occur in Anderson and Roane County portions of the reservation. Major plant communities and principal dominants are described in the following paragraphs.

Pine and Pine-Hardwood. Presently this is the most extensive type on the reservation, occupying large areas in all sectors, but particularly abundant in the northwest region. Natural forests dominated by shortleaf pine (Pinus echinata) and Virginia pine (Pinus virginiana) are associated with large tracts of planted 1oblol1y pine (Pinus taeda L.), a valuable timber species. The loblolly pine plantations are monocultures, whereas associated species in the successional forests include oaks (Quercus spp.), hickories (Carya spp.), and tulip poplar (Liriodendron tulipifera).

Hemlock, White Pine and Hardwood. This type, representing a Southern Appalachian extension of a northern (and higher elevation) forest, is extremely rare on the reservation. Small areas on Pine Ridge, Black Oak Ridge, Haw Ridge, and north of Melton Hill Dam, all on the western half of the reservation, are virtually all that remain. Total area is estimated to be no more than 99 acres (40 ha). Dominant species are hemlock (Tsuga canadensis) and white pine (Pinus strobus).

Cedar, Cedar-Pine and Cedar-Hardwood. This type is extensive on the reservation, predominating in Bethel Valley and in southern areas adjacent or close to the Clinch River and Melton Hill Reservoir. Although not uncommon anywhere, the area of this type decreases markedly north of Bear Creek Road. This type is best developed on shallow limestone (or dolomite) and appears rapidly following disturbance. Thus the present pattern reflects both substrate and the past history (recent) of land use. The dominant species is eastern red cedar (Juniperus virginiana), associated with shortleaf and Virginia pine, tulip poplar, oaks, hickories, redbud (Cercis canadensis), sassafras (Sassafras albidum), and other hardwoods.

Bottomland Hardwood. This type, restricted to small floodplains along creek bottoms, compromises a small portion of forest communities of the Oak Ridge Reservation. Small areas occur along Gum Hollow

${ }^{10}$ L. K. Mann and M. W. Bierner, Oak Ridge, Tennessee, Flora: Habitats of the Vascular Plants - Revised Inventory, ORNL/TM-5056, 1975, 141 pp. 
Creek, Bear Creek, and Grassy Creek, with larger areas along White Oak Creek and in the reservation portion of the East Fork Poplar Creek drainage. All of the type exists in the western two-thirds of the reservation. Dominant are cottonwood (Populus deltoides), sycamore (Plantanus occidentalis), elm (Ulmus americana), ash (Fraxinus spp.), willow (Salix spp.), silver maple (Acer saccharinum), and river birch (Betula nigra $)$.

Upland Hardwood. This type is important on the reservation, occupying roughly $20 \%$ of the total land area. Largest concentrations occur on Black Oak, East Fork, Pine, Chestnut, and Copper ridges. Scattered patches occur almost throughout the reservation area. This forest is essentially an oak-hickory complex, representative of the terminal type in this region of the eastern United States. Important species include ches tnut oak (Quercus prinus), white oak (Q. alba), black oak (Q. velutina), northern red oak (Q. rubra), scarTet oak (Q. coccinea), post oak (Q. stellata), various hickories (Carya spp.), and ash (Fraxinus spp.), tulip poplar (Liriodendron tulipifera), red maple (Acer rubrum), black gum (Nyssa sylvatica), dogwood (Cornus florida), beech (Fagus grandifolia), and others. A showy vernal flora is characteristic of this type, and many common wildflowers in east Tennessee are virtually restricted to upland hardwood forests.

Northern Hardwood. Northern hardwood forest is extremely rare on the Oak Ridge Reservation, occurring in small areas only on Black Oak Ridge and on Copper Ridge in the western part of the area. Composition is similar to the Upland Hardwood forest, with admixtures of sugar maple (Acer saccharum), hemlock (Isuga canadensis), basswood (Tilia heterophyl1a), and buckeye (Aesculus octandra).

Nonforest. This is a variable category that includes primarily grass lands, devegetated areas, and cultural features. The grasslands are of two types. Native or semi-native successional areas are either maintained (e.g., under power-transmission lines) or are reverting to forest. Dominants include species of bluestem (Andropogon spp.), fescue (Festuca spp.), and bluegrass (Poa spp.). CuTtivated grasslands are lawns and pastures. These predominate in and around the three $\mathrm{pl}$ ant areas (ORNL, $Y-12$, and ORGDP) and on CARL lands at the eastern extremity of the reservation. Grasses include fescues, bluegrass, and orchard grass (Dactylis glomerata) with other species.

Large tracts of bare soil occur along the shorelines of Melton Hill and Watts Bar Reservoirs. These are maintained seasonally owing to controlled fluctuation in water levels in the reservoirs. 
HABITATS OF ANIMALS OF THE OAK RIDGE RESERVATION ${ }^{11}$

The variety of wooded and open areas, as well as extensive edge communities, create habitat for numerous mammalian and avian species residing on the Oak Ridge Reservation. Both bird and mamal fauna population densities are generally correlated with vegetation cover and type.

An important factor in determining whether a given species will, in fact, occur in a given area is the nature of the habitat in the area. Small mammals, such as rodents, may be confined to a single habitat type, whereas the larger sized species may range over several habitats in order to fulfill their existence requirements. The same can be said for avian populations. Most of the birds and mammals found on the 0ak Ridge Reservation have the capability of tolerating and adapting to a variety of habitats and therefore may be found in habitats other than those which are typical for the respective species. Habitat preference for average conditions is designated in Table 2 , and some representative animal species of the habitat types are described below.

Hardwood--Mixed Hardwood Habitat

Small-mammal populations in the upland forest types of the reservation have been sampled sporadically, usually as a part of collection programs for laboratory experiments. Six species common in oak-hickory, chestnut oak, and pine forest types are the whitefooted mouse, eastern chipmunk, golden mouse, short-tailed shrew, flying squirrel, and gray squirrel. ${ }^{12}$ Both the red and the gray fox are common predators throughout the area. Opossum, raccoon, striped skunk, and bobcat inhabit numerous varied areas throughout the reservation but also roam extensively through the upland forest areas. White-tailed deer are also inhabitants of upland and bottomland forests.

The upland forest provides habitat for a large number of avian species. ${ }^{13}$ The yellow-shafted flicker is found in habitats where there are many large trees and a well-developed canopy and subcanopy.

${ }^{11}$ Summarized from: J. T. Kitchings and L. K. Mann, A Description of the Terrestrial Ecology of the Oak Ridge Environmental Research Park, USAEC Report ORNL/TM-5073. 1976

${ }^{12} \mathrm{~S}$. I. Auerbach, et al., Ecological Sciences Division Annual Progress Report for Period Ending Jüly 37, 1973, ORNL-4635, Oak Ridge National Laboratory, Oak Ridge, Tennessee, 1974.

${ }^{13} \mathrm{~S}$. H. Anderson and H. H. Shugart, "Habitat Selection of Breeding Birds in an East Tennessee Deciduous Forest," Ecology 55:828-837 (1974). 
Table 2. Typical habitat types for animals and birds of the Oak Ridge Reservation

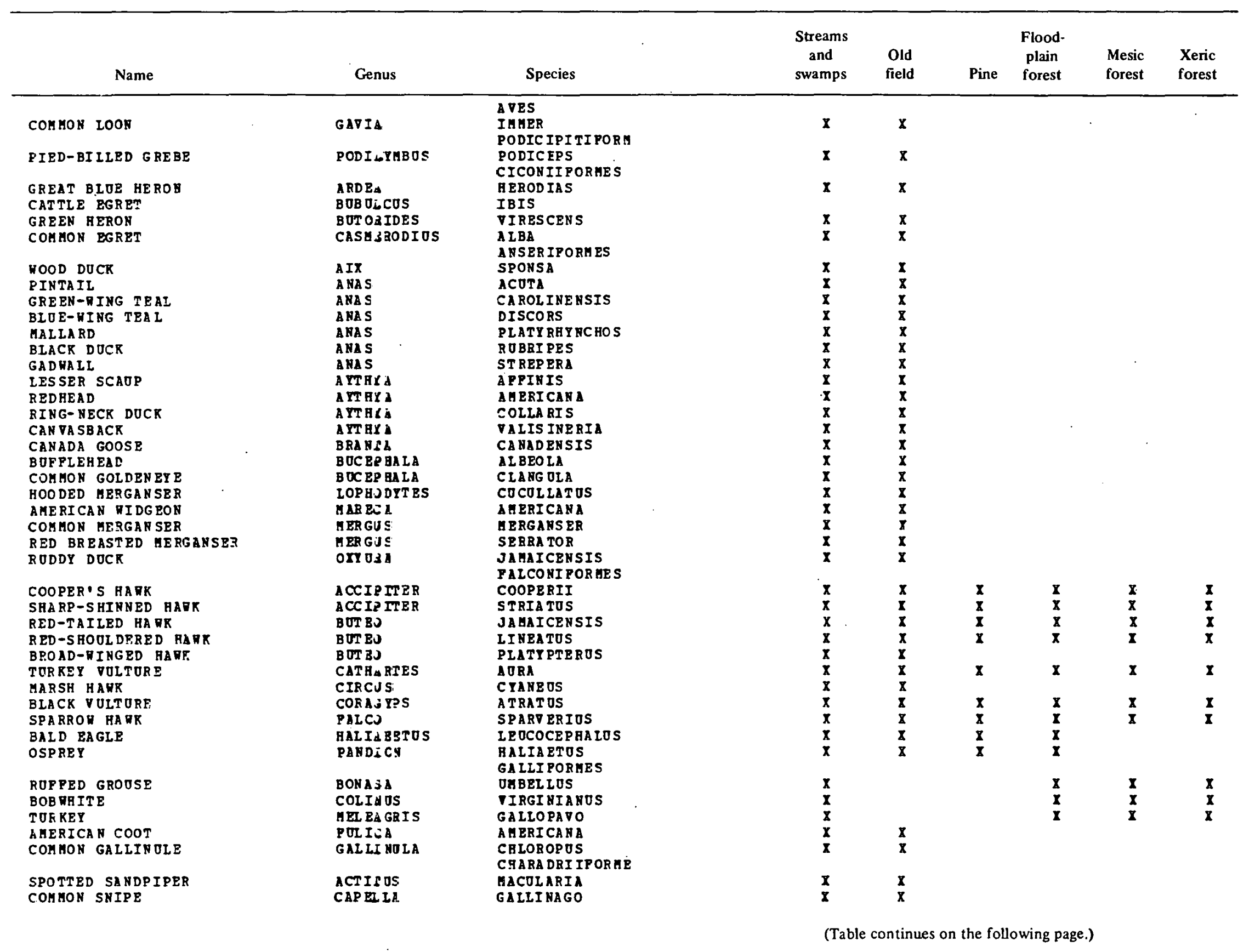


Table 2 (Continued)

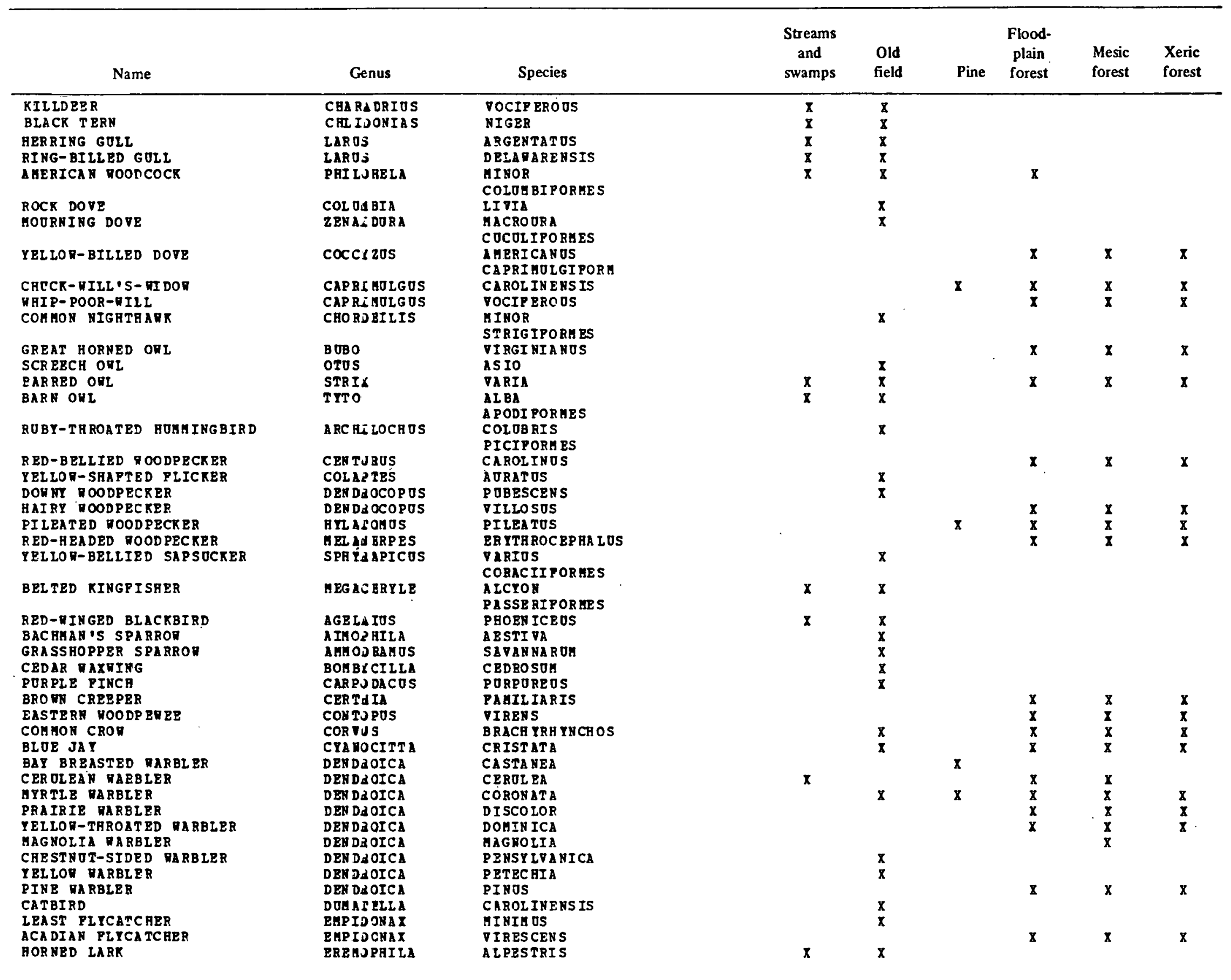


ROOD THROSR

YELLOR-BREASTED CAIT

ORCRARD ORIOLE

SIATE-COLORED JJHCO

LOGGER-ABAD SHRIKR

SRAIHSOR PS RARBLER

RED CROSSBILI

SONG SPARRON

BLACK-A ID-RHITE TARBLER

BLACR-A NDORHITE GARBLER

GREAT CRESTED PIYCATCHER

GREAT CRESTED

KENTOCKY TARBLEF

PARULA MARBLER

TOPTED TITMOOSE

CAROLINA CHIC KALEE

ENGLISH SPARROD

HEHSLOD'S SPARRON

INDIGO BOATING

ROSE-BR EASTED GPOSBEAR

RUPOUS-SIDED TORHEE

SCARLET TANAGER

SOHAER TANAGER

BLOE-GRAT GNATCATCHER

PORPLE MARTIN

PROTHOROTARY DARBLER

COH HON GRACKL E

ROBT-CROPRED KI HELET

GOL DEN-CRORNED KIBGLET

CAR DIHAL

BAYK STRLLOR

EASTERH PHOEBE

LOOISIANL VATER ERROS

\section{OPEHBIRD}

ABERICAN RPDSTAR?

EASTER BLOEBIRD

MAITE-BREASTED NOTHATCR

PINE SISKIY

AMERICA GOLDPIYCE

CAIPPING SPABRON

PT EID SPAROO

ROOGB IYGED SWALLOO

EASTERH MEADOELAER

\section{STARIIHG}

BERICK'S RREV

CAROLIYA RREN

BRO WN TRRASHER

HOOSE RER

ROBIA

EASTERH RIRGBTRD

BLOE-RIHGBD RARBLER

YELIOR-THROATED VIREO

YELLOD THROAT

BIOE GROSBEAK

DORM EATIHG VARBLER

EVENING GROSBEA

BARY SUALLOD

HERMIT THROS

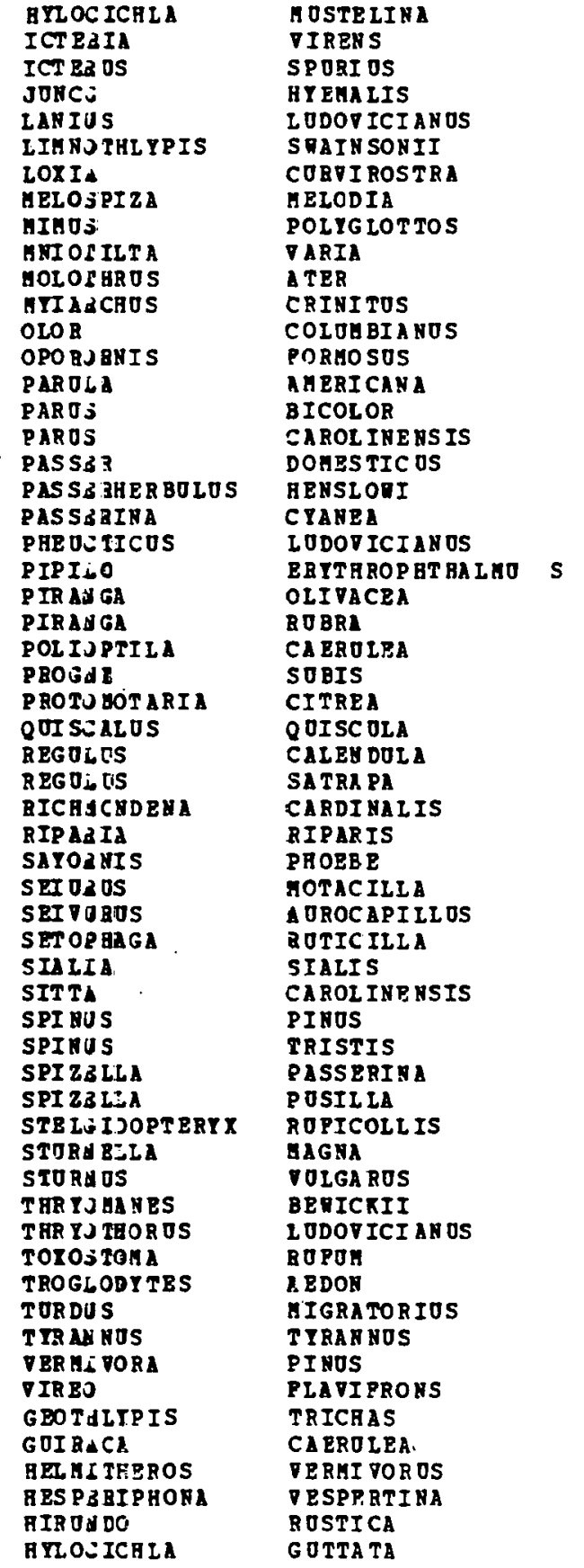

$\begin{array}{lll}\mathbf{x} & \mathbf{x} & \mathbf{x} \\ \mathbf{x} & \mathbf{x} & \mathbf{x} \\ & \mathbf{x} & \\ & \mathbf{x} & \mathbf{x} \\ \mathbf{x} & \mathbf{x} & \mathbf{x} \\ \mathbf{x} & \mathbf{x} & \mathbf{x} \\ \mathbf{x} & \mathbf{x} & \\ \mathbf{x} & \mathbf{x} & \mathbf{x}\end{array}$

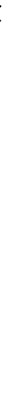

8 
Table 2 (Continued)

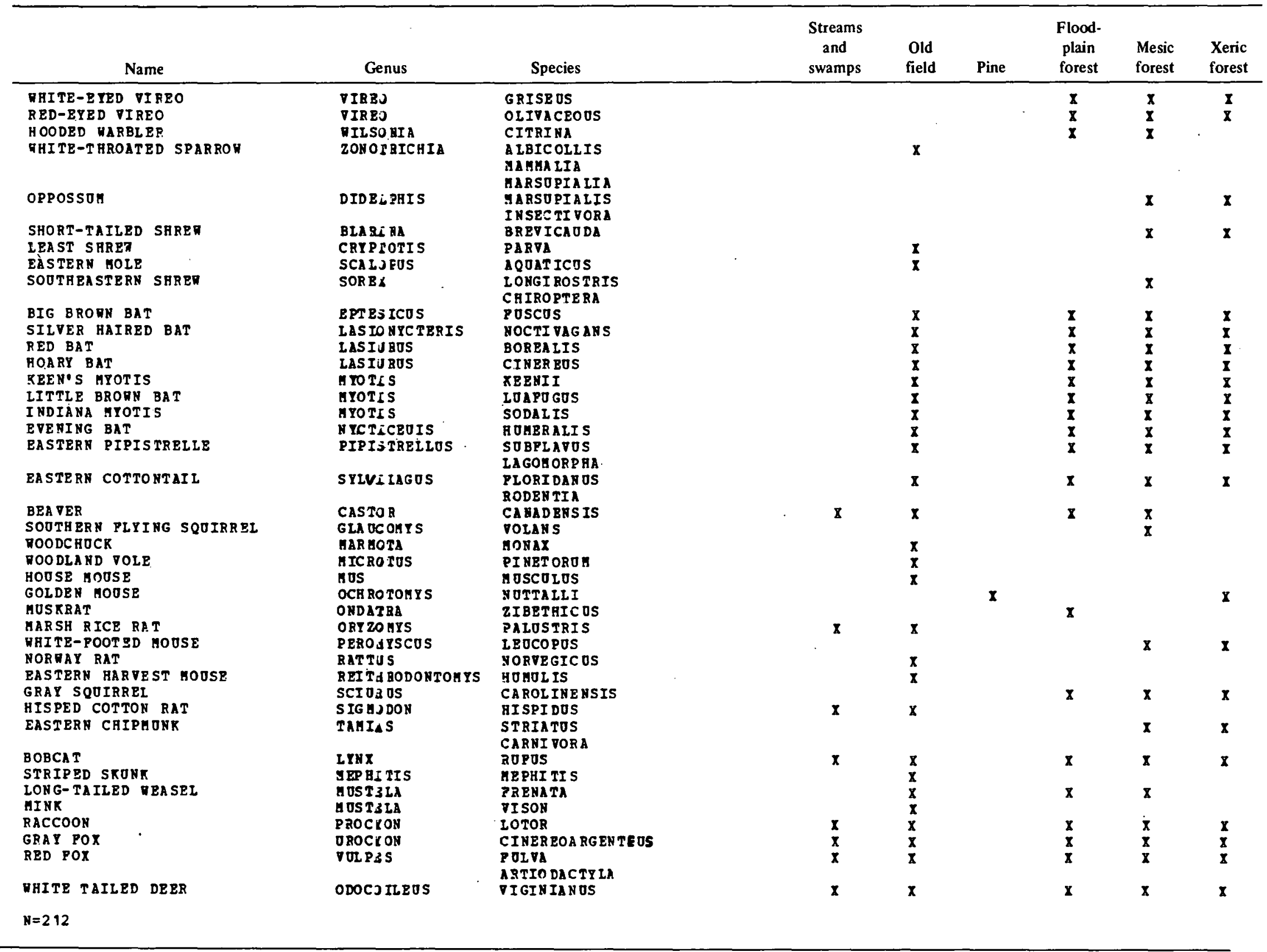


The red-bellied woodpecker is commonly found in the forest. The hairy woodpecker shows a preference for habitats with a large number of tall trees. The downy woodpecker selects areas that have more than the average number of saplings. The crow, al though not found in large numbers, uses the deciduous forest as part of its search area.

Birds typically select habitats on the basis of structure and food resources. The blue jay selects areas with a dense understory and a we11-developed canopy. The Kentucky warbler is somewhat more specialized and selects areas which have a more open overstory and which generaliy have smaller understory plants. The pine warbler selects areas with an open overstory compromised of trees with larger than average canopy and with sinaller than average trees in the lowest canopy layers. The yellow-breasted chat is found on areas with dense overstory vegetation and an open subcanopy layer and where understory plants are smaller than average. The ovenbird is found in habitats that exhibit an open tree canopy and a dense understory.

The Carolina chickadee and the tufted titmouse are considerably less selective of habitats. The scarlet tanager is distributed on sites with dense canopies. When the two tanager species are compared, the scarlet tanager is distributed according to canopy, and the summer tanager is distributed according to understory vegetation density.

A large number of raptorial birds use the woodlands on the reservation for nesting and hunting. The red-shoulder hawk and the red-tailed and. broad-winged hawks are common throughout the area.

Pine Plantation Habitat

Animal populations of the pine communities of the reservation, particularly the plantations, have not been sampled as extensively as those of the hardwood or grassland areas. A recent survey of the small-mammal inhabitants of a pine stand and an associated transmission line corridur indicates that only three species use the pine habitat to any great extent, the white-footed mouse, golden mouse, and short-tail shrew. Additional species were present (pine mouse, cotton rat, and harvest mouse), but their presence appeared to be a function of the edge community created by a transmission-line corridor. Large mammals, gray squirrels, opossum, deer, and predators probably feed and take shelter in this type of habitat.

Avian species had a low preference for the pure pine areas bordering the transmission-line corridor. The pine warbler (Dendroica pinus) and the white-throated sparrow (Zonotrichia albicollis) were very common, but few other species were heard or seen during the early morning surveys. 
01d-Field and Grassland Habitat

Mammalian species inhabiting old-field or disturbed areas are quite similar, whether the vegetative cover is early grass-forb or the later tree seedling-woody shrub successional stages. The smallmammal community structures indicative of these habitats were determined for a 0.4-acre (1-ha) area in the vicinity of the 0ak Ridge Gaseous Diffusion Plant. Small mammals trapped from this habitat type are cotton rats, white-footed mice, golden mice, rice rats, short-tailed shrews, and eastern harvest mice. Early grassland stages of old-field areas are used by some game birds, such as quail, for courtship displays and breeding purposes. Raptorial species generally use the old-field areas for hunting purposes.

Selection by bird species for old-field and grassland habitat is similar to that observed on many of the transmission-line corridors, particularly when the corridor runs through another habitat type. Sparrows, towhees, blue grosbeaks, and other field species tend to associate with vegetation within the corridor.

\section{Unique or Endangered Vertebrate Species}

Two species considered endangered by the U. S. Department of the Interior have been observed on or around the reservation. The southern bald eagle (Haliaeetus 1 . leucocephalus) has been sighted numerous times, most recently along both Melton HiTl Lake (June 1974) and Watts Bar Lake (May 1974). It nests in large trees along waterways, but no nest has been observed, and its status on the reservation is unknown. An American osprey (Pandion haliaetus) (status undetermined) was sighted along the Clinch River in May 1974. At the time it was catching fish and rarrying its prey to the bank opposite the reservation boundary. Its status on the reservation is also unknown.

\section{AQUATIC BIOTA OF THE OAK RIDGE RESERVATION}

As previously described, acquatic environs on and contiguous with the Oak Ridge Reservation include the Clinch River, several small springfed streams, and two large streams with drainage bas in areas greater than $20 \mathrm{~km}^{2}$. A listing of about 575 species found in aquatic environments on the Reservation has been compiled from environmental monitoring programs, ${ }^{14}$ from surveys by various federal (TVA, the AEC, ERDA, and NRC) and state agencies, 15 and from biotic inventories related to research projects (Table 3 ).

${ }^{14}$ Energy Research and Development Administration. 1975. Preliminary Draft Environmental Analysis, Oak Ridge Operations, Volume VI.

${ }^{15}$ Project Management Corporation. 1975. Environmental Report--Clinch River Breeder Reactor Plant, Volumes I and II. Nuclear Regulatory Commission Docket No. 50-537. 
TABLE 3. Species found in different aquatic Habitats of the oak Ridge Reservation

CLASS I PICAT ION

\section{ZOOPLAKK TON $\mathrm{c}, \mathrm{d}$}

Rotifera (and other invertetrates)

Asplanch 1 a da

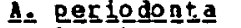

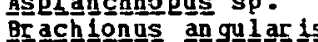

B. bidentataa․

B. Dudapestinensis

B. calycifín

B. ca ydatus

B. ha ranaesis

B. gyadridentata

B. ureolar is

Cepha1odel 1a sp.

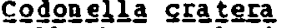

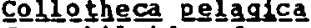

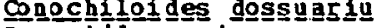

Connoghin us unjcornu

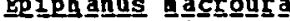

Qucㅡㄴ

$\underline{F}=$ Longisping

Pioscularia $\mathrm{sp}$

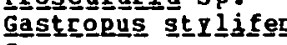

G. SP.

Habrotrococha $\mathrm{sp}$.

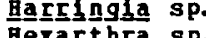

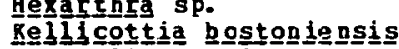

Reratel ja a gericana

$\frac{K}{2}$ cocbligaris

R. Gra

Ka

Lecape sp-

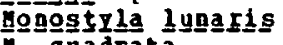

- quarata

By tilina $5 \mathrm{P}$.

Notholca gculineata

Motonnata $\mathrm{SP}$

platyos sp.

P. qu adr acorn ius

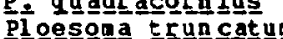

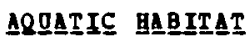

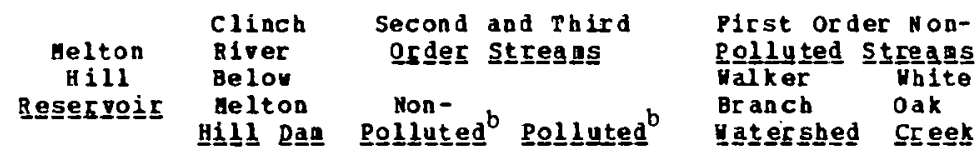

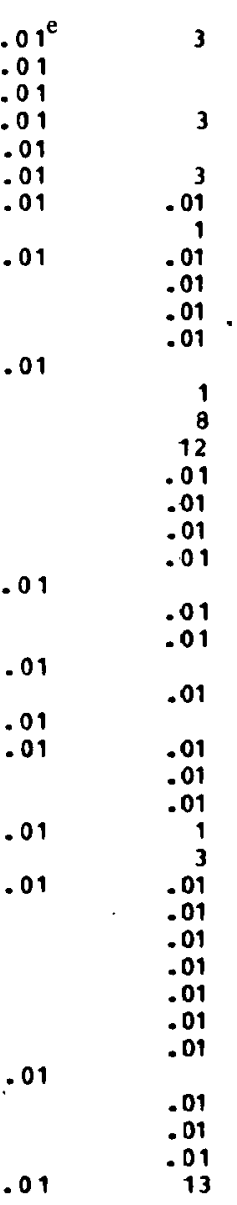




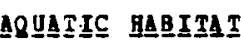

\section{CL소SSIPICA III음}

P. sp.

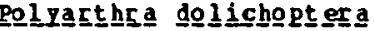

P. eysipter

$P_{2}$ gulgaris

sp.

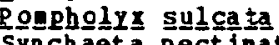

Synch habesta eectingata

s. $\mathrm{sp}$.

Testydinella $Q$ at in

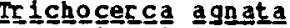

T. Cylindriea

$T=$ nultitcrinus

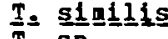

T. sp ichotrín tetraetis

T. sp.

Arthropoda

Crustacea

Bosalna longirostr is

Ceriodaphnia lacustris

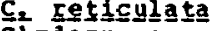

Chydorys Sp.

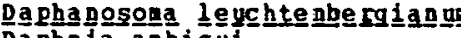

Dophñ

Q. qa leat a negdotaㅇ

D2 2axyla

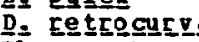

II Yoc

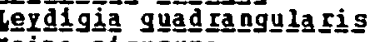

pleuroxus sp.

Seaphol ebris kingi

se

Copepoda

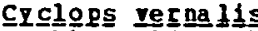

C. bicuspi dus thong

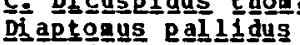

D. reighardi

D. sanguinus

Blaphoidelia bidens coranat

Brogas idus $\mathrm{sP}$

Eucycloos agils

nesocrclops eda

$\begin{array}{rr}.01 & 01 \\ .01 & 31\end{array}$

second and rhird

으deeㄷ s늘eaaㅗ

Yon-

Pollintuted Polluuㅡㅇㅛ

Pirst order Mon-

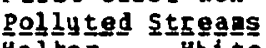
Branch ibite esecyois helt

보소니 Da․

.01

12

.01

$.01 \quad .01$

.01

$\begin{array}{ll}.01 & .01 \\ .01 & .01\end{array}$ 
In secta

Chaoㅡouuㅗ $\mathrm{sp}$.

.01

BENTHIC MACROIRVERTEBRATES,$;$

Annelida

oligochaeta

neol osom at Id ae

스으으오으므. $\mathrm{sp}$.

Branchiobdellidae

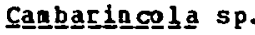

Lumbriculidae

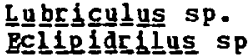

Naididae

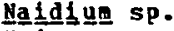

프스는 sp.

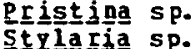

Tublficidae

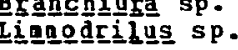

Acthropoda

rustacea

aphipoda

Gasa ar 1 dae

C도므ogognyx sp.

Gangar is 모므는

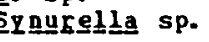

Talitridae

Hyaㅡ니른 $s p$.

\section{Decapoda}

Asticidae

Cagabar 1 is sp.

Isopoda

Asel lid ae

Aselizys sp.

Costracoda

Candoc yprinae

candoga sp. 


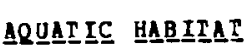

\section{CLLASSIIEICAT IOIH}

Insecta

Baet Idae

gaetis Sp.

Habrophleboides $s p$.

Isonchia sp.

paraleptophletsa sp.

Caenidae

Caenis sp.

TrIcoythodes $\mathrm{sp}$.

Epheaerellidae

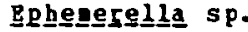

Qpheneridae

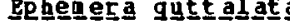
B. $\mathbf{s p}$.

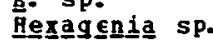

Hept ageni $i d a e$ Steㅛ으믈 $\mathrm{sp}$.

\section{odonata}

grion 1 dae

Ag디응 sp.

Bnall agna sp.

cordulegastridae

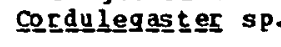

Goaphid ae

Lanthhys sp.

Plecoptera

Chloroper lid ae

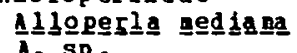

A. Sp .

Leuctridae

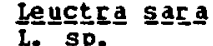

Nenouridaé

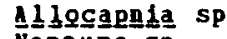

브므으므도 $\mathrm{sp}$. cond and rhir

$\begin{array}{lll} & \text { Clinch } & \text { Second and Thir } \\ \text { Melton River } & \text { grder st }\end{array}$

Hill Belou

Belou

Non-

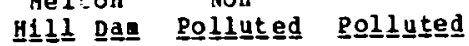

Pirst Order Non-

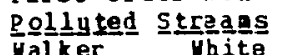

Branch oak

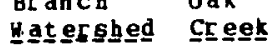

$\begin{array}{cccc}59 & 6 & & \\ .01 & .01 & 58(10) & .01 \\ .01 & .01 & 13(2) & .01 \\ & .01 & & \\ .01 & .01 & .01 \\ .01 & & .01 & .01 \\ & & & \\ & 121 & & \\ & .01 & & \end{array}$

.0

$\begin{array}{rr}39 & 24 \\ .01 & .01\end{array}$

12 (2)

.01

$11(2) \quad .01$

$\begin{array}{lll}.01 & .01 & .01 \\ & & .01\end{array}$

(n) 


\section{Peltoperlida \\ 므는operㅁa garis}

Perlidae

crongengria sp

capistata

Perlodidae

Is goper $\underline{1}$ a $\mathrm{sp}$.

Henipter a

Conixidae

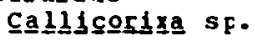

Gerridae

Ir $\underline{\text { eqgo bates }} \mathrm{sp}$.

Velildae

1 croyelia sp.

喝aqo ge1 ia $\mathrm{sp}$.

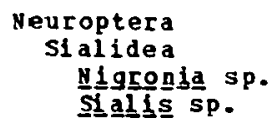

\section{glaidae}

Gonieleyeus dietrich

- sp.

Tiaiㅁyㅗ $\mathrm{sp}$

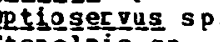

Inis sp.

y drophilida

드오브오 sp.

Psephen 1dae

Ecttopsia SP.

Psephenus sp.

Ptil odactylidae

스대고므도는 $s p$.

$\begin{array}{rrr}3 & 40(7) & .01 \\ .01 & & \\ 10 & 15(2) & .01 \\ .01 & 7(1) & \\ & .01 & \end{array}$

.01

.01

.01
.01

$\begin{array}{rrrr}2 & 3 & & \\ .01 & .01 & & .01 \\ .01 & & .01 & .01\end{array}$

.01

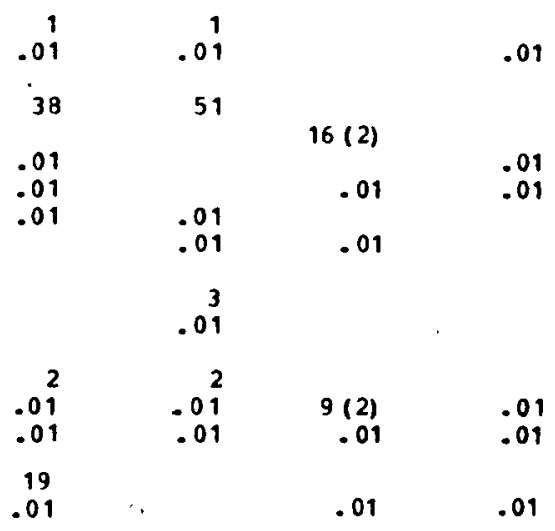

(Table continued on next page) 


\section{CLASS IPICAT ION}

Trichoptera

$$
\text { Goerca sp. }
$$

Gydrops ychidae

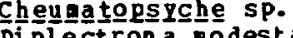$$
\text { D. sp. }
$$

바d 드으로돌 $\mathrm{sp}$.

pacaㅗ고드. $\mathrm{SP}$.

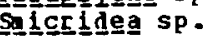

lossosomatidae 1qapetus $\mathrm{sp}$.

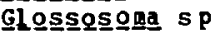

Hydroptilidae

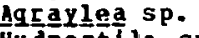

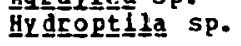

Le pi dos torat 1 dae

Lepidostoga $\mathrm{SF}$.

Leptoceridae

보sㅗaㅡ도를 $\mathrm{sp}$.

Linn ephilidae

Reophyla

sp.

\section{Molannidae}

Ho음na $\mathrm{SP}$.

odon toceridae

Psilootreta sp.

Philopotanidae

Chinarar $\mathrm{sp}$.

sychon yildae

으고른드으모 $\mathrm{sp}$.

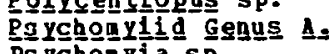

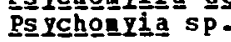

Rhyacophilidae

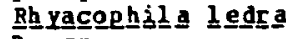

R. Sp.
AOOAIIIC HABBITAT

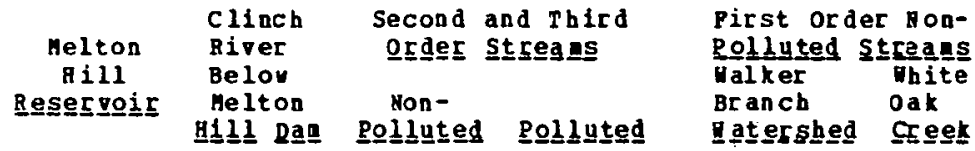

.01

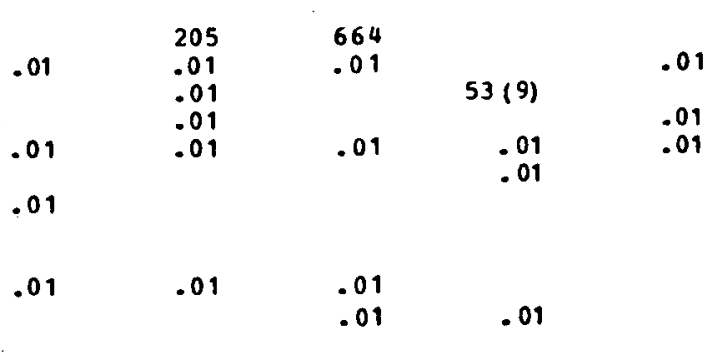

.01
.01

.01

$\begin{array}{rl}.01 & .01 \\ .01 & \end{array}$

.01

$: 01$

.01

.01

$\begin{array}{rr}10 & 35 \\ .01 & .01\end{array}$

.01

.01

1
.01

8 (1)

.01

.01

102

.01

.01 
Di ptera

topogonidae

palponyía sp.

Chirononidae

Calopsectra sp.

c1 a

Corynoneus $s p$.

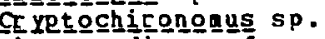

Di cEotendies $c f$. negonodestus

D. $\mathrm{Cf}$. ne다은

$\underline{\mathrm{D}}$. $\mathrm{sp}$.

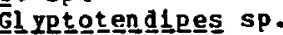

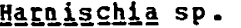

tabruudinga sp.

Larssía sp.

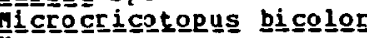

n.: 5 p.

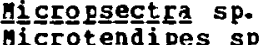

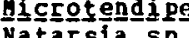

Natarasia $S p$.

Q드느음aㅁㅣㅡㄴ $\mathrm{sp}$.

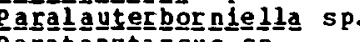

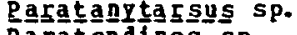

paratendinges $\mathrm{sp}$

Rentaaeㅁㄷㅗ $\mathrm{sp.}$

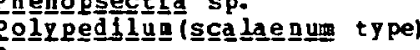

sp

Prooㅡㄴ add 1 us $s p$

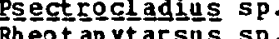

sheor a

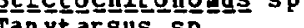

Th

onus (anceus group)

Culicidae

Ch a2 $\underline{\text { gorgus }} \mathrm{sp}$.

\section{of xidae}

Disia Sp.

Dolochopodidae

Empididae

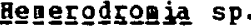

siaulidae

Siauㅡ느믐 sp.
.01

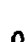

.01
.01

.01

.01

.01

.01

.01
.01

.01

.01

.01

.01
.01

.01

.01
.01

.01

.01
.01

.01

.01
.01

.01

.01

01

.01
.01

.01

01

.01

$\begin{array}{rrrrr}.01 & .01 & & .01 \\ & .01 & 1 & & \\ & .01 & .01 & .01 & \\ & & & .01 & \\ & & & .01 & \\ & & .01 & & \\ & 5 & 125 & & \\ & .01 & .01 & .01 & .01\end{array}$

( $T a b l e$ continued on next page) 


\section{CLASS IPICAT ION}

Strationyidae

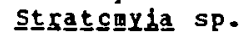

Tabanidae

Ch드노요 sp.

-abans

Dícr anota $\mathrm{sp}$.

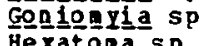

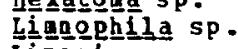

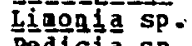

Pedicía $\mathrm{sp}$.

ps seㅁㅁoli

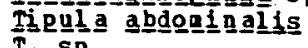

T. sp.

I도르도honona sp.

Arachnida

Acarin a

Hygrobaticae

Atragctidies sp.

Lebertidae

tebertíia sp.

Mi deopsidae

스르ogsís sp.

Sperchanidae

Sperc chon sp.

ŚpeEchonopsis sp.

Tyrrelliidae

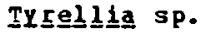

Bryozoa

Bctoprocta

Lophopodidae

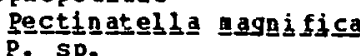

AQ느스드드 브스므노도

Clineh Second and Third

River Q더느 Streags

Beloy

Non -

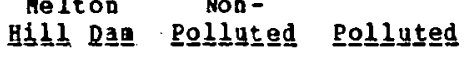

Pirst Order Non-

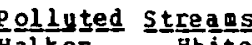

Branch wh

$\begin{array}{rr}.01 & \\ 4 & 3 \\ .01 & .01 \\ 16 & 44 \\ .01 & .01 \\ .01 & .01 \\ .01 & \\ .01 & \\ .01 & \\ .01 & .01 \\ .01 & .01 \\ .01 & .01 \\ .01 & .01 \\ .01 & \end{array}$

.01

.01
.01
.01

.01

$12(2)$

.01

.01

$.01 \quad .01$

.01

.01

.01

.01
.01

.01

.01 


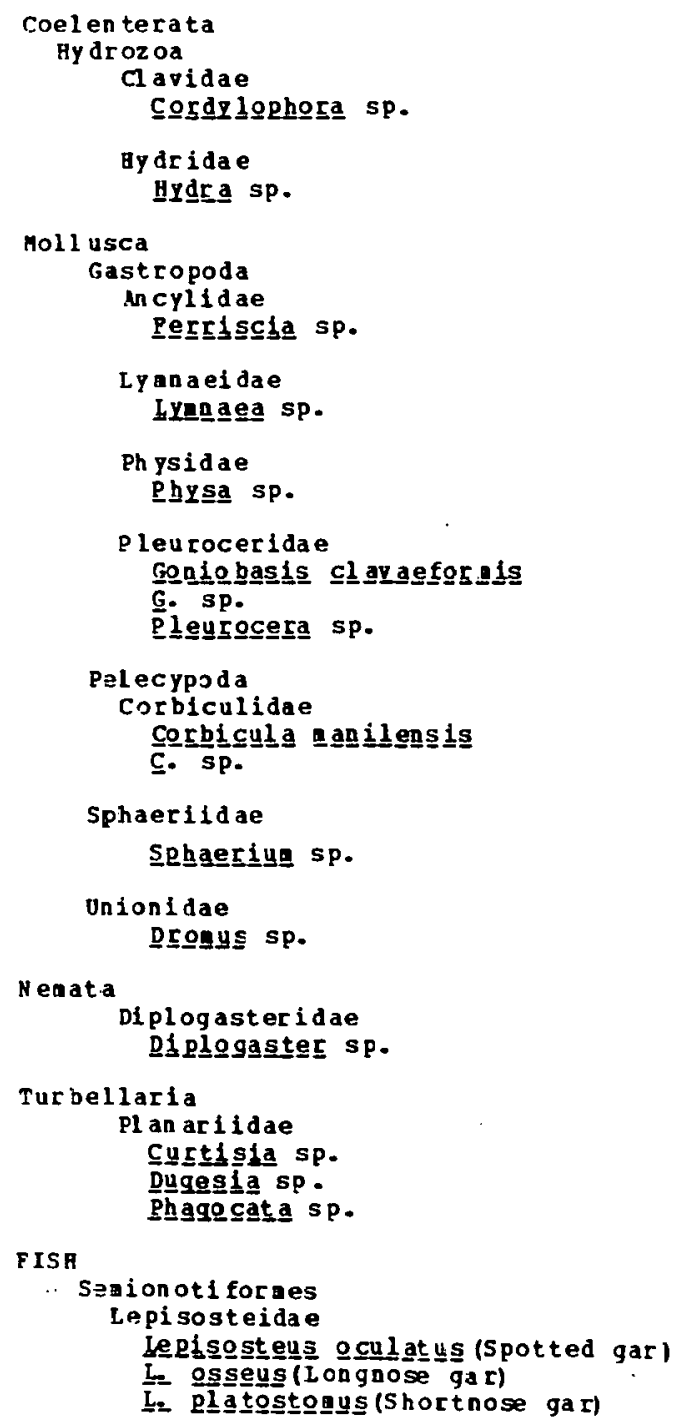

$\begin{array}{rrr} & .6 & \\ & .01 & \\ & & \\ & .01 & \\ 96 & 3 & \\ .01 & .01 & .01 \\ .01 & & \end{array}$




\section{CLLASSIPICAATIOQI}

\section{Cl upei for aes}

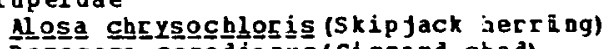

cepedianu (Gizzard shad)

D. petenense (Threadfin shad)

Hiodont idae

Hiㅡodo므 tesgís us (Boone je)

Saluonidae

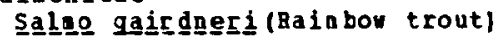

Esocidae

Bs 으 Easgud

\section{Cypriniforaes}

Cyprinidas

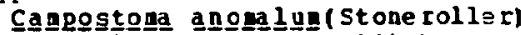

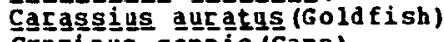

CYRrinus Carpio (Carp)

is anblops (B igeye chub)

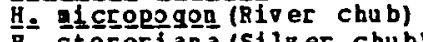

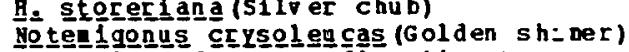

Eotroopis ardens (Rosefin s biner)

$N_{2}$ ather

H. coccogen is (Warpaint shiner)

H. connutus (Comaon shiner)

N. gal acturus (Whit et ail s biner)

Y. Sp

Pínephales notatus (Bluntnose annc.v)

$\underline{P}=$ progenelas (P a thead ainnon

P. vigiax (Bullhead ainnon

R. Cataractae (Long nose dace)

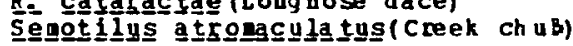

Catostonid ae

c. CYprinus

C. velifer (Highfin carpsucker)

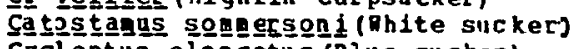

Crycleptuㅗ elóngatus (Blue sucker

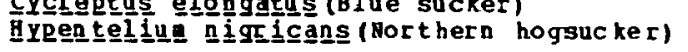

DOQATIC HABITAT

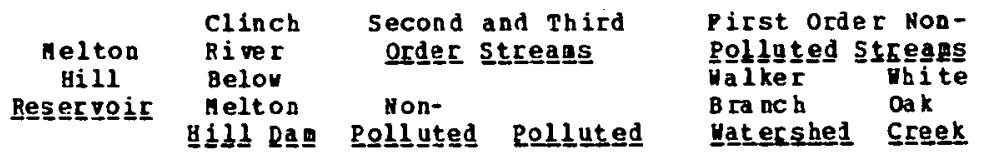

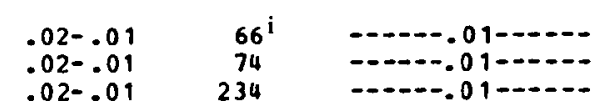

$.02 \quad 13$

.01

.01

$.02-.01$

$.02-.01$

.02

.01

.01

.02

$.02-.01$

$.02-.01$

$.02-.01$

$.02-.01$

$.02-.01$

$.02-.01$

$\cdot$

1


Ictio bus bubalus (5mall nouth buffa 10 )

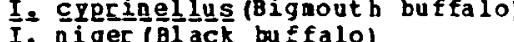

I. niger (Bick bu ffalo)

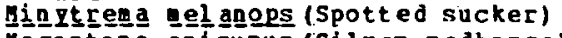

rester

I. Cas

I.

:- acrolepidotna (Shor thead red horse)

ctaluridae

Ictaluuㅗㄴ

I natalis (Yeilior bull head)

I. nebulogsus (Brown jull head)

$I=$ punct atus (chann ei cat $f$ is $h$ )

pylodictus ol 1 gar 1 s ( $P 1$ at head cat $f$ ish)

Cyprinodontiforaes

Pundulus notti (Sta rlead pinnow)

P. ol 1 vaceous (Blackspotted topai nnow)

Poecilitidae

Gagbusia affinis (hosquit ofish)

Percifornes

Perichthyidae

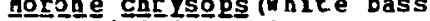

white bass $x$ (Striped bass hybrid

Centrarchidae

Aabloglites rupest $r$ jis (Rock bass)

Leoㅡㄴ is aurityg (Redbreast sunfi sh)

the CYane-11 us (Green sunf i sh)

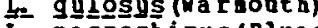

L

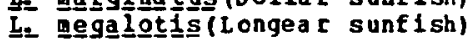

L. a $i$ crolo. 10 hus (Redeas sunfish)

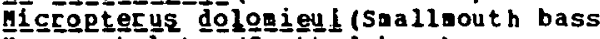

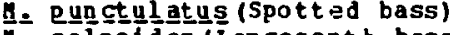

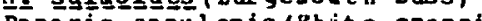

poㅡ므믄

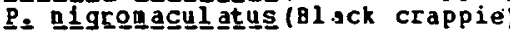

Percidac

Eth heogstoga bl engnioides (Greenside darter)

E- Jess

E. nigrya (Johnay darter)

erca f

s.
$.02-.01$

$.02-.01$

$.02-.01$
.01

$02-.01$

$.02-.01$

$.02-.0$

$.02-.01$

$.02-.01$

.01

.01

$.02-.01$

$.02-.01$

.02

.01

5

41

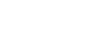

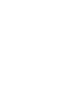

$-0.01-\cdots+-1$

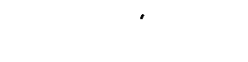

$---.01--\cdot-\cdot$

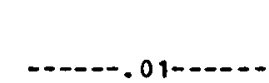

$\begin{array}{ll}.01 & 16 \\ .01 & 1\end{array}$

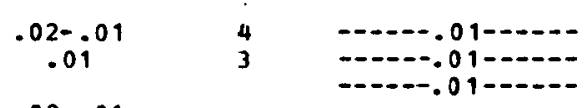

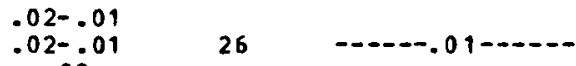

.01

.01
.01

$.02-.01$

$.02-.01$

.01

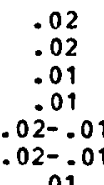

02

.01

$02-.01$

.01

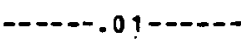

-..-. . $011-\cdots$

-...-.01-....

- - - $.011-\ldots$

(Table continued on next page) 
으모I드 브스IIIAㅗ

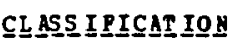

Sciaenidae

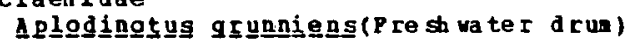

Cottidae

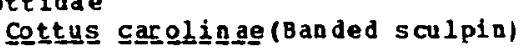

Atherinidae

Labidesthes sigGylug (Brook silverside) PER IP HY TON ${ }^{j}$

Chlorophyta (Green algae)

chlorophyceae

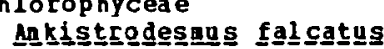

A. $\mathbf{s p .}$

Chaetophora pisifornis

Chaetospher 1djun Rringsheini

chlore릴 $\mathrm{sp}$.

ci adophora sp.

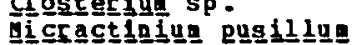

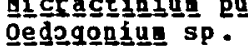

oedogonicue sp.

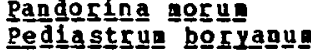

Re dyplex

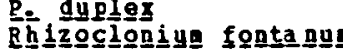

scene desexus bernard

S. bi 1uga

S. dinosphus

s. sp.

s. sp itoropsts sp

Spirogra sp.

Spirogrra sp.

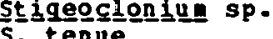

S. tenye

volvocales

Chrysoph yta (Golden or yell ow-broun)

Bacillariophyce ae (Diatons)

Achnan thes bregiges

A2 lanceola

A. sp.

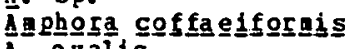

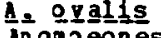

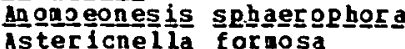

Caloneis anph joben
Second and Third

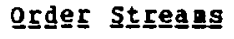

Gelton

브늘 Dag

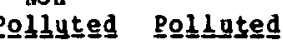

$.02-.01 \quad 17$

$.02-.01$

1

.01

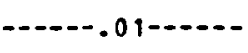

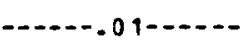

Bill Belou

$k$
$--.52(82)^{k}-$
.01
.01
.01
.01
.01
.01
.01
.01
.01
.01
.01
.01
.01
.01
.01
.01
.01
.01
.01
.01
.01
.01
.01

$---23(31)-$
.01
.01
.01
.01
.01
.01
.01
.01
Pirst Order Non-

Rolluted Stragas

Halker Thite

Haftersbed CEegk 


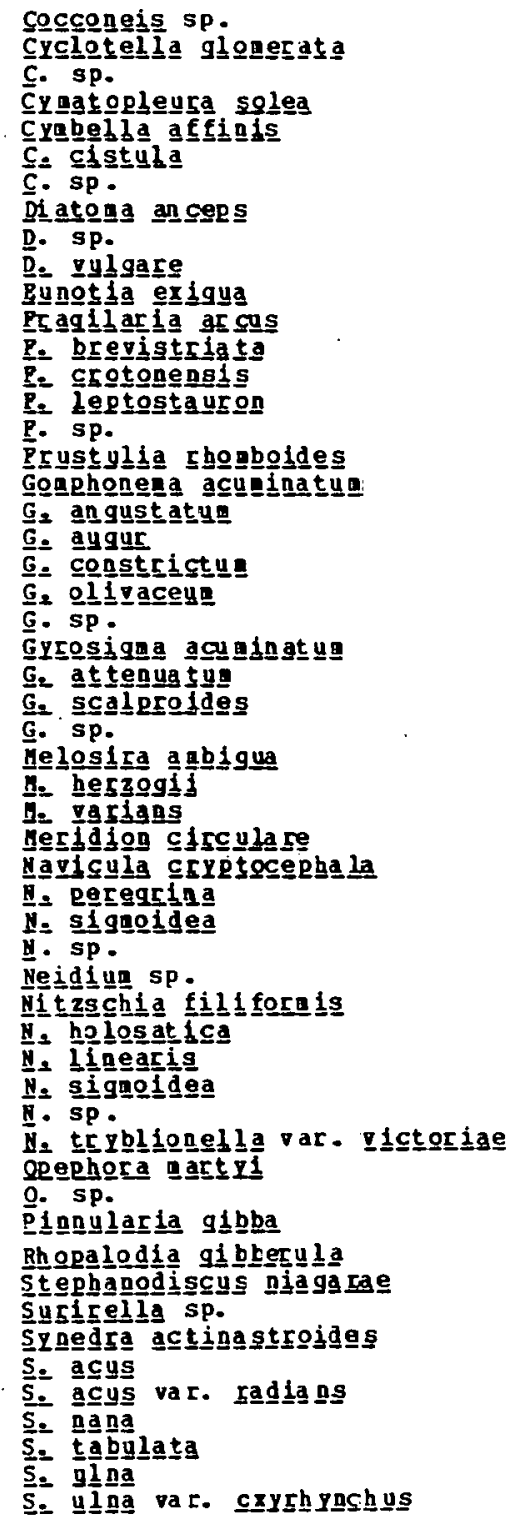


AODATIC HABITAT

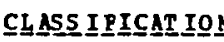

\section{S. va ycherer 1áe}

Tábel 1ar $\underline{\text { la }}$ fépestrata

T. sp.

Chrysoph pceae

Dínobryon d dyergens

D. seertularia

Xant hophyceae

Cyanophyta (Blue-green algae)

Cyan ophy ceae

Agagenelㅣㅁㅡ quadruplicatuㅡ.

A. sp.

Anacystis gontang

chroogogecus sp.

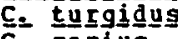

C. 모모는

Lyngbya aestuari

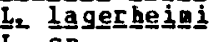

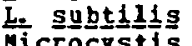

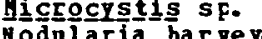

으므.

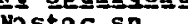

列

Q gugstissin

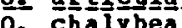

o- Chalyes

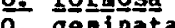

Os ornata

o. princeps

Q

o. sancta

Euglenoph yta (Buglenoids)

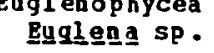

Pyrrophyta

oph yceae (Din oflagellates)

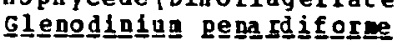

Classification - Jucertain

Cryptophyceae
Second and Ihird

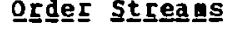

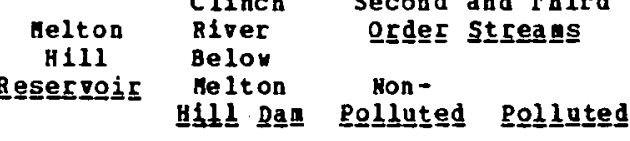

.01

.01

$-\ldots-11(21)-\ldots$

.01

$-\cdots-3(3)-\cdots$

$---15(20)-\cdots$

.01

.01

.01

.01

.01

.01
.01

.01
.01

.01

.01

.01

.01

.01

.01

.01

.01

.01

.01

.01
.01

$-.--15(56)-.01$

$---10(21)--.-01$

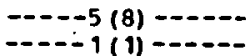

Pirst order 8 on-

Polluted Stmans

Walker

$\begin{array}{ll}\text { Branch } & \text { Oak } \\ \text { gateerghed } & \text { Cresek }\end{array}$ 
P HF TOPLANK TON

Chloroph yta (Green algae)

chlorophycea

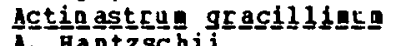

A* Hantzschij

A. Conyoluttus

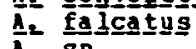

A. $\mathrm{sp}$.

A. spiraiㅗs

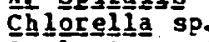

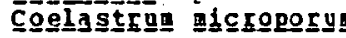

c. sp.

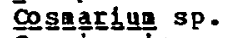

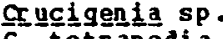

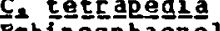

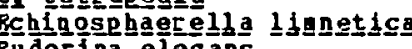

Eudorina elegans

E. sp.

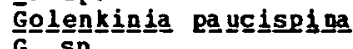

s. sp.

Gon느는 Sp.

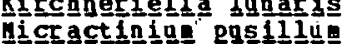

Hicract

gocrstis sp.

Pandorina so드므.

Pediastrung boryanug

$P_{2}$ dyplex

S. Becnacadi

s. bi juga

s. di doorphus

s. quadric iauda

S. qua sp.

Selen astrun sp

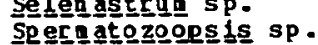

Staur astrá $u$ a chaeto ceras

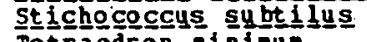

Tetra

T. Sp.

Treubari

T. sp.

Tróghiscta sp.

Chrysaphyta(Golden or yellow-brova)

Bacillariophyceae (Diatcas)

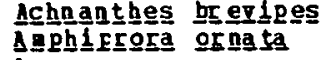

A. $\mathrm{sp}$.

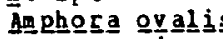

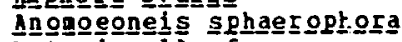

As

(Table continued on next page) 
AQUAIIC 브므ITAT

CLASS IPICAIIOI

Cocconeieis Rediculus

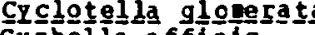

cygbeli la affínis

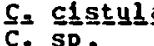

Di atoora sp

D. pulgare

extgua

ragl arila hreylstritat

P. Crogtogens

Gogphoneaㅡ ol 1 vaceg g.

Giros

janñaega a 5 çus

hantzzschhia aephioxys

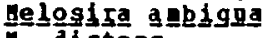

42 distang

g. herzogit

i. $\mathrm{sp}$.

I. Ta

heridion circulare

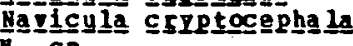

Heidive dybig.

12 3ncurgyuse

$\frac{Q}{2}=$ sigplox

tetras

19ak fosphaera gelatlnosa

Scenedes

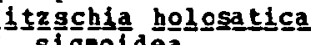

no 1 deg

geepora a art $y 1$

oph

Q

hoicosohen

Rhopaloala gi curyasa

Steph anodiscus dubius

s. sp.

Syned

$S_{2}$ acus acus
Second and Third

오der streags

River

Belon

il $\underline{1}$ Dạ

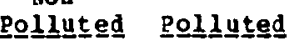

Pirst Order Non-

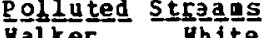

Brancb ark

.01
.01

.01
.01

.01

.01
.01
.01

.01

.01
.01

.01

.01

.01
.01

.01
.01

.01

.01

.01

.01
.01

.01

.01

.01

.01

.01

01

.01
.01

.01

.01

.01
.01
.01
.01

.01
.01

.01

.01

.01

.01

.01

.01

.01.

.01

.01 


\begin{tabular}{|c|c|}
\hline 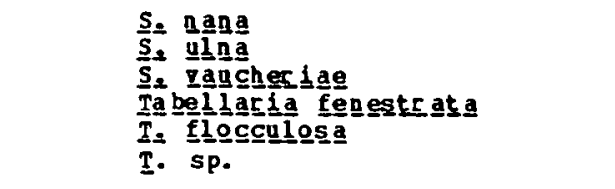 & $\begin{array}{l}.01 \\
.01 \\
.01 \\
.01 \\
.01 \\
.01\end{array}$ \\
\hline 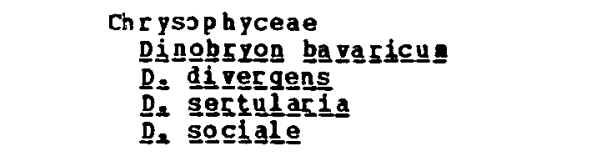 & $\begin{array}{l}.01 \\
.01 \\
.01 \\
.01\end{array}$ \\
\hline 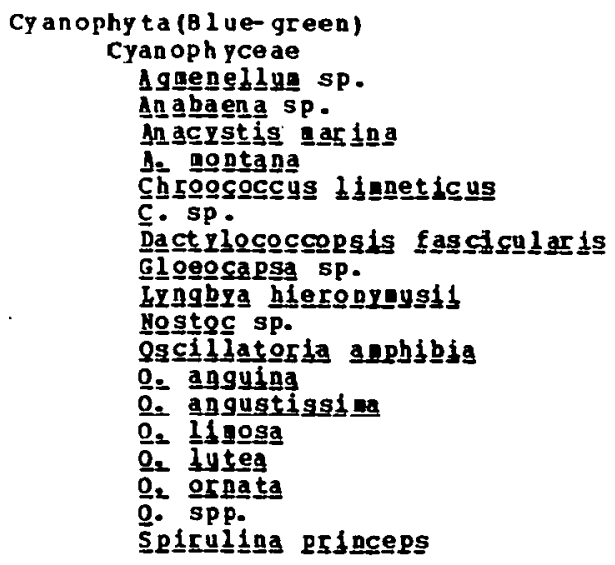 & $\begin{array}{l}.01 \\
0.01 \\
0.01 \\
0.01 \\
0.01 \\
0.01 \\
001 \\
0.01 \\
0.01 \\
0.01 \\
.01 \\
0.01 \\
.01 \\
0.01 \\
.01 \\
0.01 \\
.01 \\
.01\end{array}$ \\
\hline 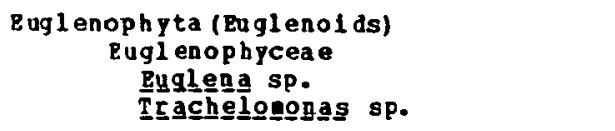 & $\begin{array}{l}.01 \\
.01\end{array}$ \\
\hline 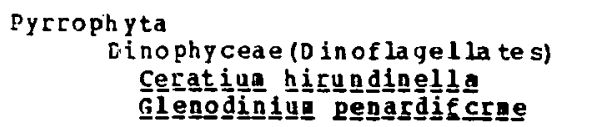 & $\begin{array}{l}.01 \\
. .01\end{array}$ \\
\hline
\end{tabular}


Footnotes to Table 3, Species Found in Different Aquatic

Habitates of the Oak Ridge Reservation

a Identification is based on H. B. Ward and G. C. Whipple, Freshwater Biology, second edition, John Wiley and Sons, Inc. N.Y. 1959; and G. M. Smith, The Freshwater Algae of the United States, second edition, McGraw-Hill Co., Inc., N.Y. 1950. Classification is based on H. B. Ward, et al.

$\mathrm{b}_{\text {Polluted streams are }} \mathrm{classed}$ as those receiving point-source releases of municipal and industrial wastes. Non-polluted streams receive no such effluents.

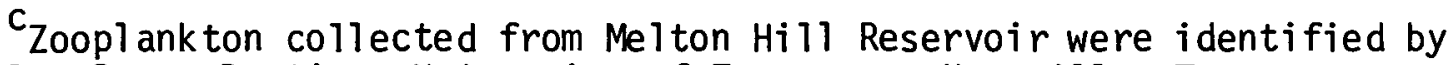
Dr. Dewey Bunting, University of Tennessee, Knoxville, Tenn.

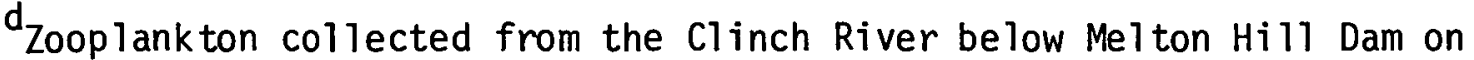
two occasions: July 26, 1973 and during the period of March 26 through September 26, 1974. Numerical data for taxa are individuals per liter.

The 0.01 notation denotes that the species were collected in at least 1 of 5 post impoundment surveys of Mel ton Hill Reservoir conducted in the period of 1963 to 1974, and that the species were observed from intermittent surveys of first, second, and third order streams of the Oak Ridge Reservation. The 0.01 notation should not be interpreted as quantitative estimates of abundance.

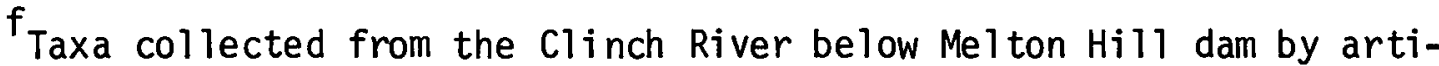
ficial substrates and dredging during the period of March 25 through September 25, 1974. Taxa from White Oak Creek collected from Petite Ponar $(6 \times 6 \mathrm{~cm})$ dredge hauls or from $1-\mathrm{ft}^{2}$ substrate collected to a depth 5-cm for the section below ORNL. For the section above ORNL, $1-\mathrm{ft}^{2}$ areas of the stream bottom were sampled. Numerical data by family represent summation values of individuals present for polluted streams (East Fork Poplar Creek, Bear Creek, White Oak Creek--below ORNL, Melton Branch, and Kerr Hollow Branch); and for the non-polluted portions of White Oak Creek (above ORNL), McCoy Branch and Kerr Hollow Branch. Summation data by families represent cumulative results for the periods of Aug.- Sept., Nov.-Dec.-Jan.-Mar. For example, a total of 28 Lumbriculidae were observed from 24 samples from the 3 nonpolluted streams as apposed to 36 Lumbriculiae from 124 samples from 6 polluted streams. When stream conditions permitted sampling, the number of samples per stream were similar at the different sampling times. 
Density and percentage abundance data for Walker Branch were based on 146 Surber samples collected during the speriod of August 1972 to December 1973. Density value is number of individuals per square meter and abundance (in parentheses) is percentage of total taxa collected. The 0.01 notation for Walker Branch indicates a species was present but it comprised less than $1 \%$ of the individuals. The non-enumerated species, as indicated by the 0.01 notation, comprised less than $10 \%$ of the total abundance.

$\mathrm{h}_{\text {The }} 0.02$ notation denotes that the species was observed in the $\mathrm{Clinch}$ River during 1960 to 1962 before impoundment of Melton Hill Dam. Before construction of Melton Hill Dam at CRM 23.1, the Clinch River arm of Watts Bar Reservoir extended to CRM 28.

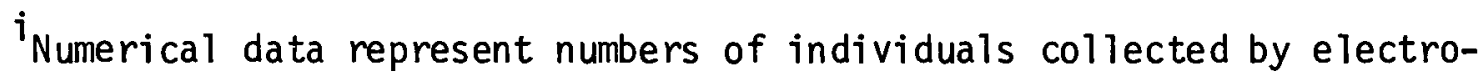
fishing and by gill netting during the period of March 28 to September 26, 1975. For example, 66 shipjack herring were collected by those methods during this period.

$\mathrm{j}_{\text {Species. were present in the Clinch River below Melton Hill Dam, during }}$ the period of March 26 to October 23, 1974.

$k_{\text {Number }}$ of genera and species is given for the major groups of algae, e.g., 52 genera and 82 species of chlorophyceae. Data collected during a preimpoundment survey (June 15 to Sept. 15, 1956), and included both free-flowing and quiescent waters of the Clinch River. Numbers of genera and species include both phytoplankton and periphyton. 
Phytoplankton in the Clinch River

Approximately 300 species of phytoplankton have been identified from the $\mathrm{Clinch}$ River in samples collected in diverse habitats extending from below Norris Dam to Watts Bar Dam (Table 3). Diatoms (Chrysophyta) dominate the phytoplankton community in the Clinch River, particularly during the spring (March-May) and early fall (AugustSeptember) periods. Blue-green algae (Cyanophyta) frequently dominate the phytoplankton community during the mid-summer (June-July) period. Green algae (Chlorophyta), Euglenophyta and dinoflagellates occur in most phytoplankton samples and are abundant in localized areas of the Clinch River during certain periods of the year.

Chlorophyll a concentrations in the $\mathrm{Cl}$ inch River from JuneSeptember range from $2.2-6.0 \mathrm{mg}^{-3} .{ }^{15}$ The mean pheophytin a ratio for the June-September, 1974, period was 1.3 , with a range of 1.0 to 1.6 .

Periphyton in the Clinch River

The periphyton community in the $\mathrm{Cl}$ inch River below Melton $\mathrm{Hill}$ Dam is dominated by diatoms (Table 3 ). ${ }^{15}$ Cell densities on plexiglas slides in 1974 were found to range from approximately $1 \times 10^{5}$ cells $\mathrm{cm}^{-2}$ in March to $4 \times 10^{6} \mathrm{cell} / \mathrm{s} \mathrm{cm}^{-2}$ in 0ctober. Cell densities are lowest from late winter to early spring and highest from late summer to early fall. The annual succession of periphyton in the Clinch River below Melton Hill Dam appears to parallel successional trends noted previously for the phytoplankton. The Chrysophyta (mostly diatoms) reach a high density early in the spring and maintain their abundance throughout the summer. Densities of Cyanophyta (blue-green algae) increase during the summer and reach a peak in october. Ash-free dry weight measurements of periphyton on artificial substrates during the May-August, 1974 period were found to range from 700 to $4600 \mathrm{mg} \mathrm{m}^{-2}$.

Zooplankton in the Clinch River

Approximately 50 species of zooplankton, 16 species of arthropods, and 40 species of rotifers have been identified from the Clinch River and Melton Uill Reservoir (Table 3). Members of the orders Cladocera and Copepoda in the Clinch River compose nearly the entire arthropod population. Dominant rotifer species include Keratella earlinae, K. coch learis, Polyarthra vulgaris, Conochilus unicornis, and Synchaeta spp. Dominant cladocerans are Bosmina Tongirostris, Diaphanosoma leuchtenbergianum, and Daphnia retrocurva. Population peaks of zooplankton occur in May and August in the Clinch River below Melton Hill Dam and result primarily from increases in numbers of rotifers. 
Benthic Macroinvertebrates in the Clinch River

Benthic macroinvertebrates in the Clinch River include mollusks, annelids, flatworms (Turbelluia) coelenterates, and insects (Table 3 and ref. 15). The distribution and abundance of benthic invertebrates are dependent on several factors, including depth, substrate composition, and substrate particle size. The Diptera, Annelids, and Mollusca dominate the benthos in terms of numbers during most of the year. In May and August, Hydra dominates the benthic macroinvertebrate community. The dominant species of other groups include Corbicula (Mollusca), Limnodrilus (Annelida), Polypedilum and Glyptotendipes (Diptera). Density of benthic macroinvertebrates in the Clinch River below Melton Hill Dam have been found to range from $75 \mathrm{~m}^{-2}$ in May when Hydra dominated the benthic community. Diversity of the benthic invertebrate community in the Clinch River is low, averaging less than 2 for the Shannon-Wiener index. This low diversity is probably due to the low substrate diversity in the Clinch River both above and below Melton Hill Dam.

Macrophytes in the $\mathrm{Clinch}$ River

A limited inventory of aquatic vascular plants for aquatic habitate is available from several sources.10,16,17 Aquatic macrophytes collected from shallow areas of Melton Hill Reservoir include Potamogeton sp., Chara sp., Nais sp., Elodea sp., and Myriophyllum spicatum. ${ }^{15}$ Myriophyllum is the dominant macrophyte in Mel ton Hi17 Reservoir, reaching high levels of density in some shallow areas. A macrophyte control program by TVA is conducted to reduce the nuisance growths of Myriophyllum in Melton Hill Reservoir. Occasional growths of the bryophyte Fontinal is and the leafy liverwort Scapania were encountered in sampling for macrophyte below Melton Hill Dam. Changing water levels, high turbidity and the TVA control program are probably responsible for the low abundance of macrophyte communities in this portion of the Clinch River.

\section{Fish in Clinch River}

A total of 71 fish species belonging to 16 families have been identified from the $\mathrm{Clinch}$ River (Table 3 ). Forage fish, mostly gizzard shad and threadfin shad, accounted for approximately $54 \%$ of the fish sampled below Melton Hill Dam in 1974, while rough and game fish accounted for the remaining 33.6 and $12.4 \%$, respectively. ${ }^{15}$ Bluegill was the most

${ }^{16} \mathrm{~F}$. G. Taylor, Phenological Records of Vascular Plants at Oak Ridge, Tennessee, ORNL-IBP-69-7, 1969 .

${ }^{17} \mathrm{~J}$. S. 01son, G. Cristofolini, and S. Cristofolini (eds.), Oak Ridge, Tennessee, Flora: 1. Preliminary Alphabetic Inventory of Vascular Plants, ORNL/TM-1232, 1966. 
abundant game fish, and skipjack herring was the most abundant rough fish. 15

Migrating fish species in the Clinch River include the sauger, white bass, skipjack herring, and striped bass. Rainbow trout are in the Clinch River, but their distribution is primarily limited to the cold-water region below Norris Dam.

In sampling below Melton Hill Dam, only 30 fish species belonging to 10 families have been identified. The lower diversity of fish below Melton Hill Dam is probably due in part to the use of size selective sampling methods used (electrofishing and gill netting) which tend to exclude small species from being collected. No quantitative data are available on standing crops of fish in the Clinch River.

\section{Biota of streams on the Oak Ridge Reservation}

Most of the streams on the 0ak Ridge Reservation have drainage basins of less than $20 \mathrm{~km}^{2}$ and annual flow rates of less than $10 \mathrm{cfs}$ $\left(0.3 \mathrm{~m}^{3} \mathrm{sec}^{-1}\right)$. Stream depths typically are less than $1 \mathrm{~m}$, with alternating ripples and pools. The small streams draining forest catchments on the reservation such as Walker Branch are heterotrophically based. Periphyton communities in these streams are dominated by diatoms with relatively low cell densities $\left(10^{4}\right.$ cells $\left.\mathrm{cm}^{-2}\right)$ compared to cell densities of periphyton in the Clinch River $\left(10^{5}\right.$ to $10^{6}$ cells $\left.\mathrm{cm}^{-2}\right){ }^{18}$ Primary production rates in the forested streams average less than $1 \mathrm{~g}$ organic matter $\mathrm{m}^{-2}$ day. $^{-1} .^{19}$ Macrophytes in the small streams include watercress (Nasturtium officinale), false loosestrife (Ludwigia spp.), and moss (Fontinalis sp.).

Benthic invertebrate communities in the streams on the Reservation are dominated by aquatic insects, followed in order by Mollusca, 0ligochaeta, and Crustacea (Table 3). The mean annual standing crop of aquatic insects in Walker Branch is approximately $1.5 \mathrm{~g}$ (wet weight) $\mathrm{m}^{-2}$. The mean density of all benthic invertebrates is approximately 600 individuals $\mathrm{m}^{-2}$.

Diversity of benthic invertebrates in streams on the Reservation that receive industrial effluents generally is lower than the uncontaminated, forested streams. Possible reasons for the lower benthic diversity include lower diversity of substrate types, particularly in

${ }^{18}$ Radiation Ecology Section. 1970. Progress in terrestrial and freshwater ecology, Health Physics Division Annual Progress Report for period ending July 31, 1969. ORNL-4446.

${ }^{19}$ Elwood, J. W., and D. J. Nelson. 1972. Periphyton production and grazing rates in a stream measured with a ${ }^{32} \mathrm{P}$ material balance method. 0ikos 23: 295-303. 
the larger streams that receive heavy silt loads, and discharges of industrial and municipal effluents which are toxic to aquatic biota. ${ }^{14}$

Fish species in the smaller streams on the Reservation include shiners (Notropis spp.), dace (Rhinichthys spp.), and minnows (Pimephales spp.) (Table 3). Fish species collected in the larger streams such as East Fork of Poplar Creek and Poplar Creek include larger species such as largemouth bass, and rock bass which move up from the Clinch River.

Species lists of aquatic biota in some of the other aquatic environments on the 0ak Ridge Reservation are either incomplete or are based on sampling done over 20 years ago. Species 1 ists for White Oak Lake and White Oak Creek based on surveys done in the early 1950's are available in References 20,21, and 22. Species lists for ponds and on the Reservation quarries such as Rogers Quarry which are aquatic research sites have not been compiled.

\section{IMPORTANT NATURAL AREAS AND ARCHAEOLOGICAL SITES} OF THE OAK RIDGE RESERVATION

Protection afforded by the Oak Ridge Reservation has resulted in the preservation of several areas whose species composition and/or stage of development make them of considerable scientific value. The biotic composition of these areas has been described in a recent publication. ${ }^{10}$ Continued protection of unique and natural areas is one concern of Environmental Sciences Division programs. Area summaries and locations of the natural areas (including protective zones), potential archaeological sites, ${ }^{23}$ and other cultural features are given in Table 4 and Map 5.

The significance of the unique natural and cultural areas is the commitment to preserve the unique or representative biotic features and archaeological and other cultural features of the reservation for research

${ }^{20}$ Krumholz, Louis A. 1954. An ecological survey of White Oak Creek. United States Atomic Energy Commission, Division of Technical Information. OR0-587 (Volume I). $158 \mathrm{pp}$.

${ }^{21}$ Krumholz, Louis A. 1954. An ecological survey of the limnology of White Oak Creek and Lake. United States Atomic Energy Commission, Division of Technical Information. OR0-587 (Volume II). 180 pp.

${ }^{22}$ Krumholz, Louis A. 1954. An ecological survey of the vertebrate fauna of White Oak Lake and environs. United States Atomic Energy Commission, Division of Technical Information. OR0-587 Volume III). $208 \mathrm{pp}$.

${ }^{23}$ G. F. Fielder, Jr., An Archaeological Survey with Emphasis on Prehistoric Sites of the Oak Ridge Reservation, Oak Ridge, Tennessee, USAEC Report ORNL/TM-4694, Department of Anthropology, University of Tennessee, 1974. 
Table 4. Summary of areas used for established programs of environmental and agricultural research

\begin{tabular}{lc}
\hline \multicolumn{1}{c}{ Research category $^{\mathrm{a}}$} & Hectares \\
\hline Terrestrial (Map 6) & 2156 \\
Aquatic $^{\text {(Map 7) }}$ & 2828 \\
Agricultural $^{\text {C (Map 8) }}$ & 1032 \\
Natural, cultural, antiquities (Map 5) & 603 \\
\hline
\end{tabular}

${ }^{a}$ Overlap exists primarily on terrestrial and aquatic research rategnries.

${ }^{b}$ Area includes associated drainage basins.

${ }^{\mathrm{C}}$ Area excludes forest land. 
ORNL-DWG 75-6040

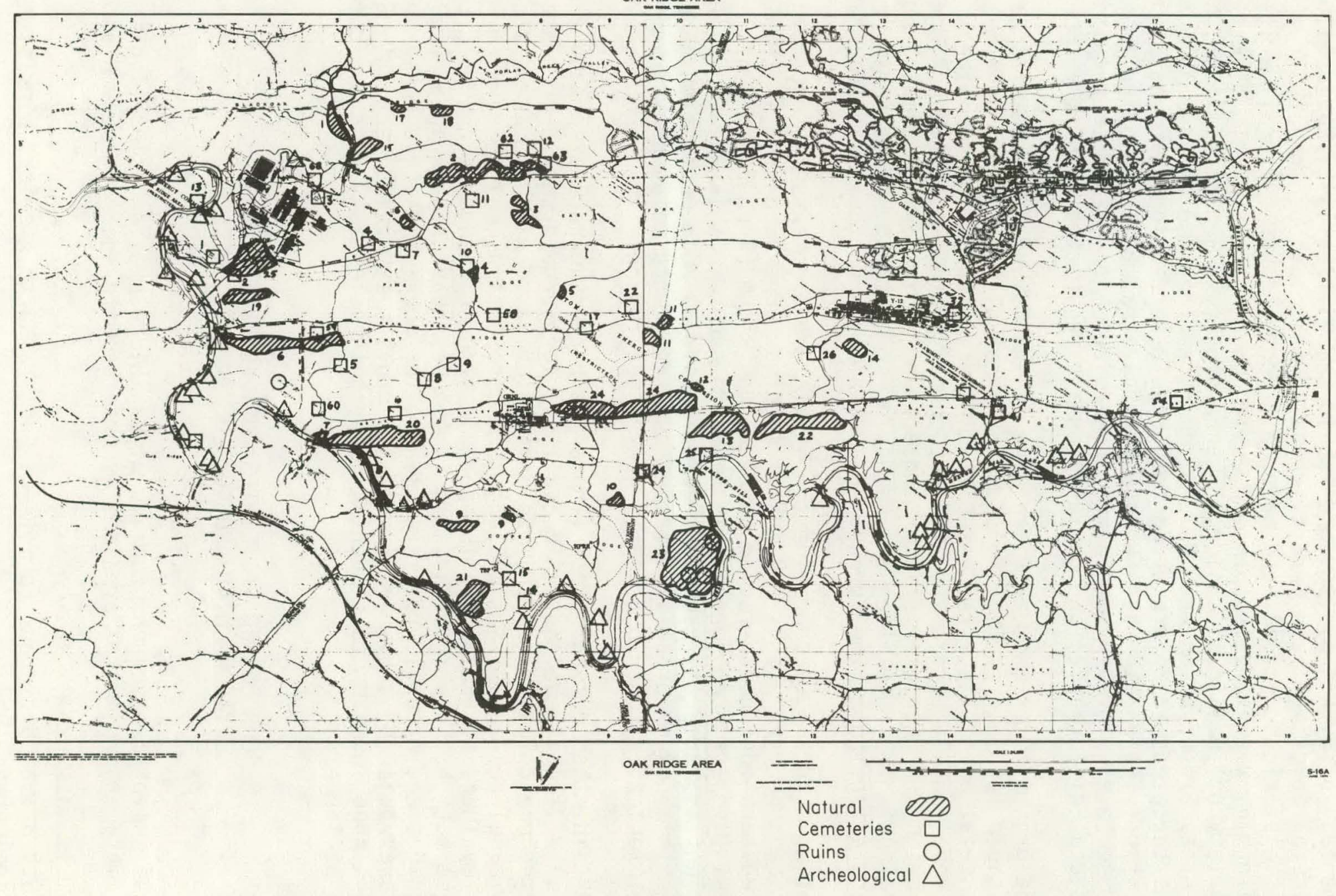

Map 5. Unique natural and cultural areas. 
and education of present and future generations. This is consistent with recommendations of select Federal councils and panels. The National Environmental Policy Act of 1969 and Public Law 93-205, 1973, have obligated the Federal Government and Federal research institutions to "preserve important historic, cultural, and natural aspects of our national heritage and maintain, wherever possible, an environment which supports diversity and variety of individual choice." Tennessee State Senate Bill 366, Natural Areas Preservation Act of 1971, embraces the same philosophy but divides the areas to be preserved into Scenic-Recreational and NaturalScientific. Designation as a unique natural area means exclusion from other use (e.g., forestry management or environmental research requiring significant disturbance) and designation for restricted access.

The proximity of the Oak Ridge area to the Cumberland Mountains is responsible for the reservation's dominant oak-hickory association's strong relation to the mixed mesophytic associations of more northern moist cove and slope forests. The ecological systems of the Oak Ridge Reservation are characteristic of those found in the intermountain regions of Appalachia from the Allegheny Mountains in southern Pennsylvania to the southern extension of the Cumberland Mountains in northern Alabama. ${ }^{24}$

Unique natural areas provide the habitat requirements for especially significant or rare plants and animal species. One such area is the sheltered western-most north-facing coves of Haw Ridge (Area 20, Map 5). Golden seal (Hydrastis canadensis) is known to occur in this area and since this plant is rare, its habitat should receive as much protection as possible. This unique area is important as a reference area, and it serves as a biological refuge in a heavily developed region.

Certain other natural areas (those not harboring rare or endangered species) will continue to remain available for nondestructive or nonmanipulated ecological research. In particular, some of these areas can act as baselines against which long-term observations Illdy be carried out to evaluate natural and anthropogenic induced changes and trends on the reservation, in particular, and in the southeast region in general. Some unique and natural areas are useable for nonmanipulative research, and preservation of these areas can also provide supervised educational and training opportunities to students, university scientists, and the community at large.

RESOURCES AND FACILITIES FOR RESEARCH IN THE ENVIRONMENTAL AND AGRICULTURAL SCIENCES

Environmental research programs at Oak Ridge provide scientific insights into environmental problems associated with energy research and

\footnotetext{
${ }^{24}$ E. Lucy Braun, Deciduous Forests of Eastern North America, Blakiston, Philadelphia. 1950.
} 
development. These programs encompass al1 aspects of the movement, metabolism, and effects of energy-related toxic agents in ecological, agricultural, and biological sectors of man's environment. Present use of land and water resources is designed to ensure that sufficient and appropriate areas are available for experimental purposes consistent with immediate and future priorities and objectives of the ERDA mission. Identification of lands possessing suitable characteristics for sustained agricultural and forest productivity, as well as those containing suitable terrestrial and aquatic habitats will aid ERDA in fulfilling its environmental-research mission. Field-resource needs are based on established and ongoing research programs, on immediate requirements for field facilities as outlined in the ORNL five-year research plan, and on anticipated long-term (5, 10, or 20 years) directions and needs for land and water resources for ecological and agricultural research.

Areas designated in this report for research purposes include the range of habitat diversity typical of the region. They are further delineated to include environmental conditions (e.g., relief, geology, soils, water quality, stream characteristics, and specific biotic associations) required for the likely range of research objectives. The nature of the research often requires long-term commitment of the area. Specific treatments to research areas are carried out consistent with research plans, sound health and safety policies, and other procedures that are compatible with onsite technological research. Treatment or use of research areas (e.g., disease control and fire control) is coordinated with established programs at the Oak Ridge site.

Undisturbed land and water resources represent valuable reference areas against which environmental effects of energy technologies can be gauged. Included in the legends for Maps 6 and 7 are selected locations (0812, 0913, 0919, 0922, 0923, VII) that currently serve as controlled reference areas. Judicious future use of these resources will facilitate rigorous testing of scientific questions and hypothesis related to potential or alleged environmental impact of nuclear or nonnuclear technologies.

Areds designated for research purposes also include agriculturally improved land. This land has been selected and improved on the basis of the U. S. Department of Agriculture land classification system and the proximity of the land to the research facilities on Bethel Valley Road. The criteria for classification are the same as those given for agricultural productivity (see page 6 ). When most of the best agricultural land (type 1, soil class I) was flooded by activation of Melton Hill Dam, virtually all the remaining land of this type on the reservation was cleared and developed by TVA. The acreage of land reclaimed by TVA to replace that lost by the raised lake level was less than the total lost to Melton Hill Lake because sufficient type I and type II I and was not available on the reservation. There is an acute shortage of type I and type II land on the reservation. A11 areas in reasonable proximity to CARL are currently being used by CARL for established research projects. 
Legend for Map 6. Terrestrial Research Areas

0090 Mammal study area south of Lagoon Rd. (5 acres, 2 ha)

0100 Environmental monitoring area (20 acres, 8 ha)

0400 Transmission-1ine management area (35 acres, 15 ha)

0450 Transmission-1ine corridor effects study (30 acres, 12 ha)

0800 Postattack research area--NOAA Meteorological Research Area ( 125 acres, $50 \mathrm{ha}$ )

0801 Raccoon Creek watershed ( 1060 acres, 430 ha)

0805 "0." -segment tree nursery area ( 115 acres, 45 ha)

0809 Cooling-tower drift study area (920 acres, 370 ha)

0810 Tritium study area (20 acres, 8 ha)

0852 Grubb Island embayment animal collection area west of Raccoon Creek embayment ( 10 acres, $4 \mathrm{ha}$ )

0913 McNew Hollow watershed (proposed) (165 acres, 65 ha)

0914 Laboratory water supply and Chestnut Ridge control ( 4 acres, $1.6 \mathrm{ha}$ )

0915 Walker Branch power-line research area, Bird and mammal studies (north edge of 0919) (15 acres, 6 ha)

0916 Northern cove animal collection area northeast of 0919 (60 acres, $25 \mathrm{ha}$ )

0917 Forest contamination area ( 135 acres, 55 ha)

0919 Walker Branch watershed (515 acres, 210 ha)

0921 White 0ak Creek watershed (735 acres, 300 ha)

0923 Gumm Branch watershed ( 330 acres, 135 ha)

0924 Bethel Valley quarry (10 acres, 4 ha)

3599 Environmental monitoring area (10 acres, 4 ha)

4552 Environmental monitoring area (65 acres, $25 \mathrm{ha}$ )

7565 Environmental monitoring area (70 acres, 30 ha)

7650 Radioisotope-tracer study area ( 15 acres, 6 ha)

7655 Radioisotope-tracer study area (2 acres, 1 ha)

7660 Melton Hill embayment (410 acres, $165 \mathrm{ha}$ )

7730 Animal population collection areas ( 145 acres, 60 ha)

7733 Melton Hill Lake and aquatic monitoring area ( 75 acres, $30 \mathrm{ha}$ )

7754 Terrestrial radionuclide cycling area (155 acres, 65 ha)

7851 Environmental monitoring area (60 acres, 25 ha)

7950 Radioisotope-tracer area ( 5 acres, 2 ha)

7951 Radioisotope-tracer area (3 acres, 1.2 ha)

Not on Map

0812 Terrestrial and environmental quality research areas

0918 Animal population and collection area

0922 Terrestrial and environmental quality research areas

7732 Animal population and collection area

7734 Animal population and collection area 
ORNL-DWG $75-6037$

OAK RIDGE AREA

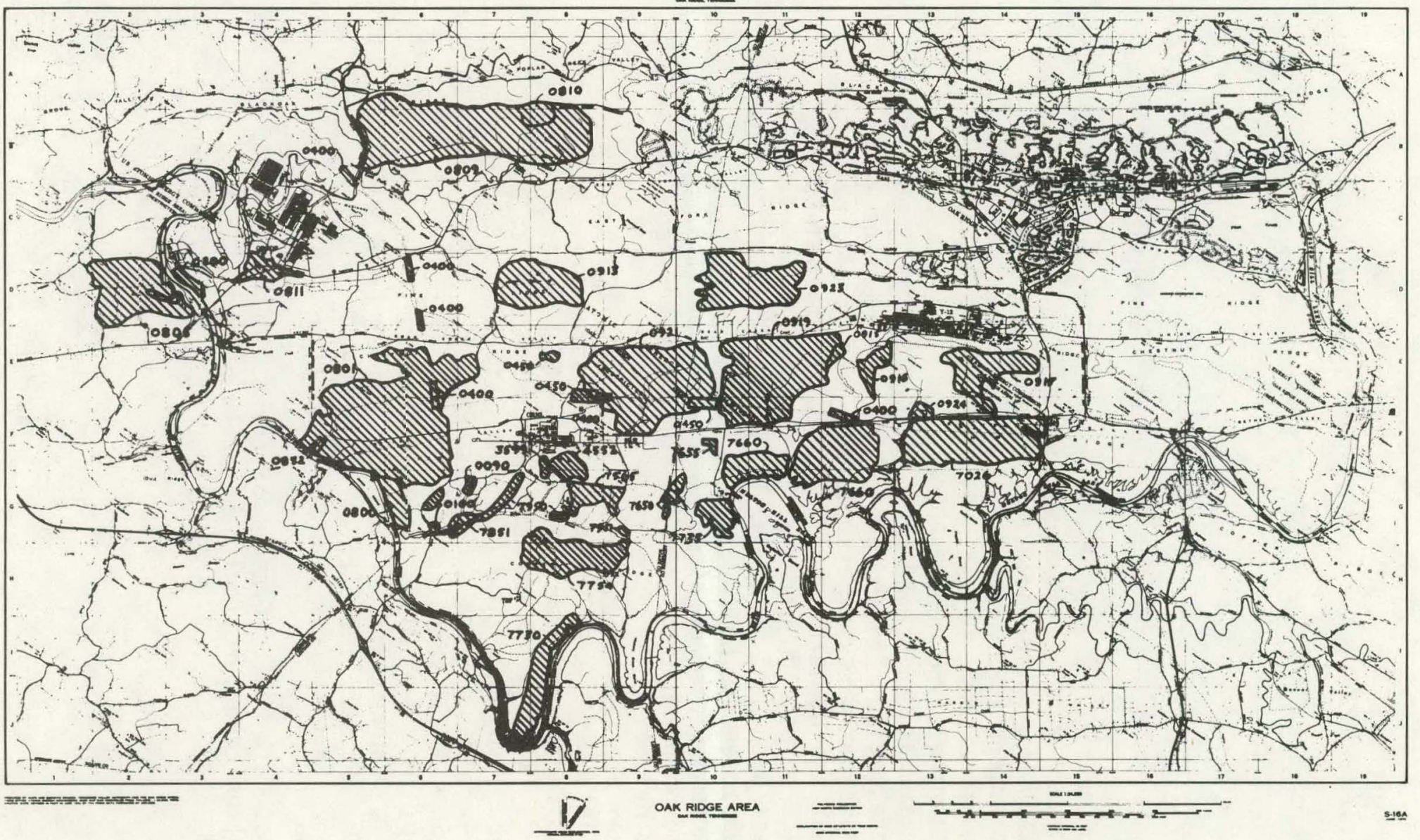

Map 6. Terrestrial research areas. 
Legend for Map 7. Aquatic Research Areas

I. Lambert quarry ( 140 acres, 55 ha)

II. McCoy Branch, Bethel Valley quarry and associated watershed (430 acres, $175 \mathrm{ha}$ )

III. Walker Branch, Melton Hill embayment and associated watershed ( 750 acres, 305 ha)

IV. White Oak Creek watershed, White Oak Creek, White Oak Lake, Melton Branch, Melton Branch watershed, and White Oak Creek embayment (2750 acres, 1115 ha)

V. ORNL spring water supply and associated watershed (425 acres, $170 \mathrm{ha}$ )

VI. West Branch of White Oak Creek and associated watershed (95 acres, 40 ha)

VII. Raccoon Creek and associated watershed (310 acres, 125 ha)

VIII. Scarboro embayment and Kerr Hollow watershed ( 100 acres, $40 \mathrm{ha}$ )

IX. Bear Creek drainage basin (710 acres, 285 ha)

X. Clinch River and Poplar Creek research areas and monitoring stations ( $38 \mathrm{~b}$ acres, $15 b$ ha)

$X-2$. Roberts Branch embayment ( 65 acres, 25 ha)

$\mathrm{X}-3$. Embayment pond ( 20 acres, $20 \mathrm{ha}$ )

X-4. Poplar Creek (45 acres, 20 ha)

$X-5$. CRM 11 sampling station ( 40 acres, 15 ha)

$X-6$. Mouth of Ellis Creek ( 35 acres, 14 ha)

X-7. Convergence of East Fork Poplar Creek with Poplar Creek (25 acres, $10 \mathrm{ha}$ )

X-8. Grassy Creek embayment (60 acres, 25 ha)

XI. East Fork Poplar Creek (755 acres, 305 ha)

XII. Melton Lake waterfowl habitat (135 acres, 55 ha) 
ORNL-DWG 75-6038

OAK RIDGE AREA

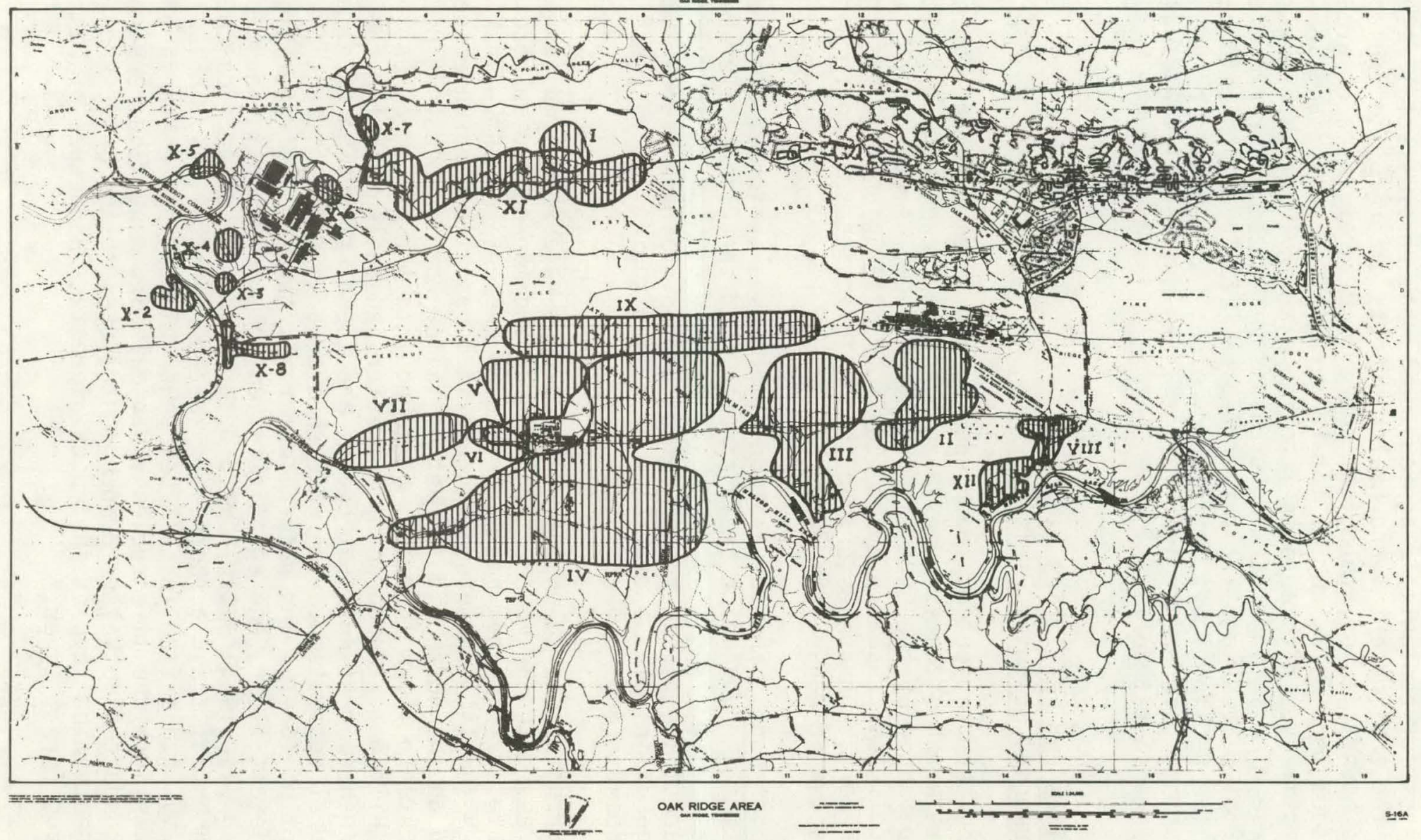

Map 7. Aquatic research areas. 
The Environmental Sciences Division, ORNL, and the Comparative Animal Research Laboratory are currently using or have immediate plans to use 49 field sites for ecological, agricultural, and environmental research related to the environmental and health aspects of energy technology. Locations and boundaries of ecological and agricultural research areas are illustrated on Maps 6, 7, and 8, for terrestrial, aquatic, and CARL facilities respectively. With advance research planning, the opportunity for intensive use of existing research areas is maximized. For example, the East Fork Poplar Creek aquatic research area (III) overlaps with parts of area 0809, the Cooling Tower Drift Study area. As a result of such overlap, the summary data on acreage (Table 4) are not mutually exclusive for each research category.

Research Sites and Facilities used by the Environmental Sciences Division

The long-term protection, maintenance, and development of current and potential research sites is necessary to ensure the high-quality research standards demanded by the ERDA mission objectives. Areas currently being used for ecological research by the Environmental Sciences Division on the Oak Ridge Reservation are described in the following sections. Research areas are shown in Maps 6 and 7.

Watersheds. The reservation comprises a series of small drainage basins through which small streams feed the $\mathrm{Cl}$ inch River-Melton $\mathrm{Hi} 11$ Reservoir. These watersheds generally drop about $60 \mathrm{~m}$ from the head of the stream to the outlet of the drainage basin. Small drainage basins play a central role in monitoring the response of landscapes to environmental impacts.

Current research on the Walker Branch watershed area (area 0919) is addressed to the movement of natural and man-caused soluble and insoluble particulates and materials in the environment. This research facility is unique because it is a calibrated watershed. Located on the north side of Bethel Valley Road on Chestnut Ridge, Walker Branch flows from the watershed into the embayment on Melton Hill Dam. Research at the watershed deals with the fundamental behavior of nutrient cycles and the distribution of elements in natural ecosystems. The watershed area is used to quantify the movement of foreign and natural materials through the vegetation, soil, forest floor, and aquatic systems of the natural landscape. Research also is directed toward determining the effects on the environment of toxic airborne and waterborne materials, including the heavy metals from fossil-fuel power plants, and entrance of these materials into the life cycles of animals and man. The research being conducted on Walker Branch contributes to the basic knowledge of biogeochemical cycles in typical forested landscapes of Eastern Deciduous Forest types. 
OAK RIDGE AREA

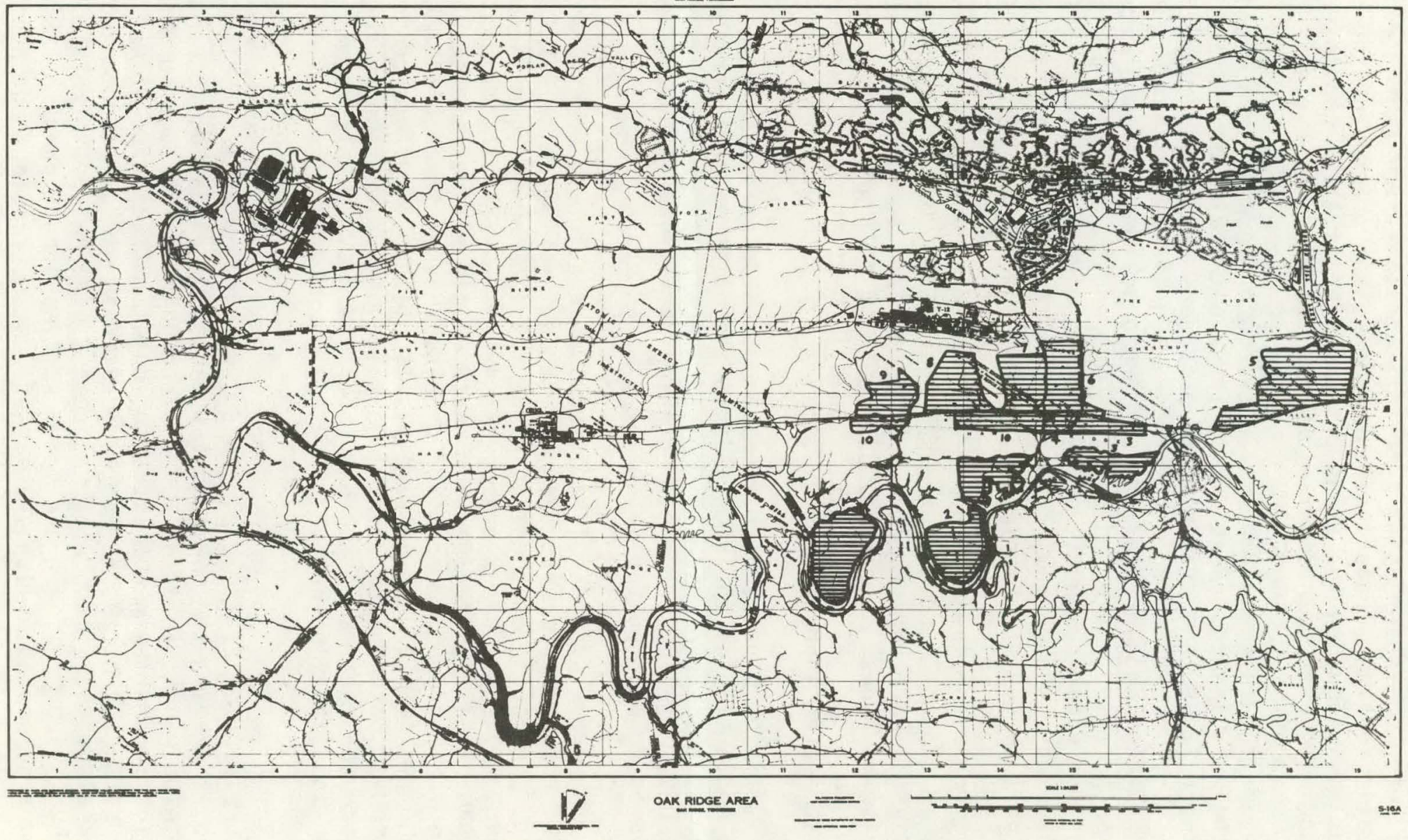

Map 8. CARL programmatic land. 
Associated with the Walker Branch watershed is the Walker Branch embayment (area 7660) which is currently being studied to delineate the movement of nutrient materials from terrestrial to aquatic systems. Future research on Walker Branch and the embayment will focus on the transport and fate of trace contaminants associated with both fossil-fuel and nuclear-fuel cycles.

Sma11 watersheds in area 7660 (south slopes of Haw Ridge) are being established. Research at these sites will be related to the fate, effects, and transport of emissions from coal combustion.

Radioisotope Tracer Areas. Radionuclides are used within seven forested areas south and east of ORNL and on the crest and slopes of Chestnut Ridge southeast of $\mathrm{Y}-12$. These research areas include 0810, 0917, 7754, 7655, 7650, 7951, and 7950 and contain approximately 335 acres (136 ha). They are used for an ongoing program of radionuclide cycling studies in natural and manipulated forested ecosystems. One area irretrievably committed to research is the site of a ${ }^{137} \mathrm{Cs}-$ tagged plot of hardwoods and shrubs (7754). Other locations (7950 and 7951) have experiments on both soil and trees tagged with radioactive nuclides. Location 0917 south of $\mathrm{Y}-12$ where the sludge from New Hope Pond is dumped is included in near-future plans for studying contaminated 1 andscapes.

Tritium studies have been conducted in a forested area (0810) on the north side of the ERDA Reservation. The western portion of area 0810 is also being used to monitor trace contaminants transported in the ORGDP cooling tower plumes which drift over the area; the remaining area is to be used for potential program expansion.

Numerous studies of radionuclide behavior in aquatic and terrestrial envirumients have been carricd out in the White Dak. Crepk watershed. Beginning on Chestnut Ridge and flowing through the ORNL compound, White Oak Creek passes by several burial grounds and sites contaminated with radioactive waste. This entire watershed is invaluable for radionuclide cycling studies that explore questions about the long-term fate of radioactive wastes placed in surface geological formations. Both Melton Branch and White Oak Creek receive chronic and low concentrations of radionuclides and heavy metals in effluents from laboratory operations.

Experimental Field Plot and Tree Nursery Area (0800). The 0800 area is devoted to low-intensity radiation research; it contains an infinite-plane radiation source incorporated into the surface soil. This site is firmly committed to long-term radiation-effect studies. The site ( 125 acres; $51 \mathrm{ha}$ ) is located in an isolated controlled area along the Clinch River southeast of ORNL west of State Highway 95. 01d-field and scrub species occupy parts of the area accompanied by large areas of fescue grassland and nonforest 
vegetation. Part of the area is used for long-term studies to evaluate the radiation dose and environmental effects that may arise in a post-attack situation. Experiments are also conducted on small rodents, insects, and plants of agricultural importance. The site is fully instrumented. A 10-acre (4-ha) tract containing the experimental plots with cesium-tagged fallout simulant is enclosed by antipersonnel fencing and marked with appropriate hazard signs. The area also contains a meteorological monitoring tower operated by the Atmospheric Turbulence and Diffusion Laboratory (ERDA-NOAA).

Part of the area is in forestry compartment 20 , which contains an experimental apparatus for investigating the microclimate interface between forested and open lands. Near the radioactive plots, but south of the White Oak Creek-Lake outlet, is scrub growth and an ecological animal-trapping area. This site provides animals and ecological data for use in the post-attack studies.

Research activities will be intensified in this area. The most fertile soil on the ERDA Reservation is derived from terraces formed by floods of the Clinch River. Tree nurseries for research purposes will be established in areas formerly used as topsoil borrow pits. The tree nurseries are necessary for developing and maintaining experimental materials of uniform genetic stocks. Such biological material is essential for research on the effects of pollutants on -ecosystems that will arise from new programs in nonnuclear energy technology.

Environmental Monitoring Areas. Environmental monitoring areas are located in areas 7851, 0100, 7565, 4552, and 3599 in a forested drainage adjacent to White Oak Creek and Melton Branch, to the south and southwest of ORNL and adjacent to the radioactive-waste burial grounds. The area includes White Oak Lake and its outlet at the Clinch River. Approximately 225 acres (91 ha) are included in the area.

Ecological monitoring is conducted routinely by the Operations and Health Physics Divisions of ORNL to follow the seepage of radioactive wastes, trace the pathways of radionuclides, and to assess the effects of low-level radiation exposure to the natural habitat, including the vegetation and aquatic environments of White Oak Lake. Practical aspects of the monitoring program deal with safety considerations of radioactive-waste disposal.

Laboratory Water Supply and Chestnut Ridge Control Site. Area 0914 (north of ORNL) is a drainage basin containing a spring, pumping station, and well; pipelines supplying research facilities at ORNL are located in this area. It is imperative that this water source be protected because it serves as the water supply for aquatic experiments conducted by the ORNL Environmental Sciences Division at Buildings 2001, 1504 and the Environmental Sciences Laboratory. As such this research area is committed in support of aquatic research. 
This area has served as a source of experimental organisms and natural and high-quality water to support the long-term aquatic ecology studies dealing with radioactive tracer and productivity studies and, more recently, the developing program on thermal effects of effluents from power reactors. A portion of the area is in forestry compartment 15, and forest management practices within the area are modified to ensure protection of the wells and springs located here.

Animal Population and Collecting Areas. Areas 0852, 0916, and 7730 , south of the Tower Shielding Facility (TSF), are used for the collection of mammals for laboratory experiments or as field sites for studies on the relation of structural forest parameters and small-mammal population dynamics. These areas provide opportunity for program expansion in the 1892 acres (766 ha) located on diverse terrain and habitat, including grassland portions of the ERDA reservation managed by the CARL.

Area 0090 is currently being used to establish the dissemination of radionuclide waste from a waste disposal area by small-mammal populations. This area is also being used to correlate small-mammal species and the structural components of the plant community that they inhabit.

Lands within these areas are used for multipurpose activities by both the Environmental Sciences Division of ORNL and the CARL facility. Parts of the area are in forestry compartments 23 and 24. Small plots within the area serve as collection sites for small mammals that show uniform nutritional and physiological conditions when reared in the same locale. Uniformity of research organisms is necessary for detecting the often subtle responses to low-level environmental stresses.

0 -Segment Tree Nursery Area. The 0 segment (0805) is located across the Clinch River west of ORGDP and consists of partially cleared and forested land. Forestry compartment 4 encompasses the entire area. Portions of this 115-acre (46-ha) tract have been used for military training purposes under agreement between ERDA and the Tennessee National Guard. The Tennessee Game and Fish Commission also maintains a wildlife management program on the area under a permit granted by ERDA.

The 0 segment also contains a nursery for the propagation of cottonwood clones and seedlings used as experimental material for research programs on effects of nuclear and nonnuclear pollutants. Adjacent to the nursery are areas in the early successional stage of revegetation which are used to supply animal species indigenous to such habitat. Flatlands in the northwest corner of the area are designated as an experimental area for studying radiation effects on small mammals. Sloughs on the southeast side of the area $(x-2$, 
Map 7) are used as collecting areas for carp, mosquitofish, midges, and other biological specimens in support of the ongoing aquatic research program.

Bethel Valley Quarry. The deep limestone quarry adjacent to Bethe 7 Valley Road (area 0924) is currently used as a waste-disposal site and receives overflow from the $Y-12$ ash pit. The quarry drains into a small tertiary stream crossing the CARL control area. On this site the ORNL Environmental Sciences Division is investigating movements of toxic materials in the environment and the dispersal and settling characteristics of particulate materials in waste. The site contains 10 acres ( 4 ha).

Transmission-Line Research Areas. Six management areas designated as 0400 have been established in cooperation with TVA to evaluate alternative techniques of power-line right-of-way maintenance. Ecological studies of various combinations of cover plants, represented by both shrubs and grasses, are being conducted. Alternative techniques are being compared for their effectiveness in protecting the site and their potential for sheltering and feeding small game and rodents. Studies are being conducted under varying conditions and habitat so the results may be generally applied to regional problems of power-line maintenance. Approximately 65 acres ( $26 \mathrm{ha}$ ) are devoted to these studies. Additional areas marked as 0915 and 0450 are being used to determine the effects on small-mammal and bird communities following modification of forest habitats for transmission-line corridor construction and maintenance.

Cooling-Tower (ORGDP) Drift Study Area. Downwind areas within area 0809 east and northeast of ORGDP, in the valley floor traversed by Blair Road and Poplar Creek, are used to study the distribution and the effects of water and chemical additives from the cooling towers at ORGDP. Additional land for these studies is also needed in the 0 segment across the river from the plant. Part of the area scheduled for study lies in the buffer zone around ORGDP as well. Area 0809 contains approximately 920 acres (372 ha).

Special Habitats for Aquatic Research. Several quarries, small streams with associated watersheds, and miscellaneous habitats are located on the ERDA Reservation. Lambert quarry (area I) is isolated, and access can be controlled. There is a small associated watershed. Research on fish tracking and the cycling of trace contaminants is in progress at Lambert quarry.

McCoy Branch, Bethel Valley Quarry. The associated watersheds (area I I) are being studied to determine transport of trace contaminants that are released from a fly-ash tailings pond east of Fanny Knob. Research will continue on transport, cycling, and effects of trace contaminants from fly ash in aquatic ecosystems inhabitating this site. 
Bear Creek. Although highly impacted by drainage from acid pits near $\mathrm{Y}-12$, Bear Creek (area IX) is a valuable aquatic habitat because of the opportunity to study recovery following cessation of acid and nitrate pollution. The creek has several monitoring stations, and the backlog of data will provide the basis for before-and-after comparisons during the recovery process.

Clinch River and Poplar Creek. The embayments of the $\mathrm{Cl}$ inch River and a section of Poplar Creek are used for fish population studies and as aquatic monitoring stations. Roberts Branch embayment (area $X-2$ ) located just below Gallaher Bridge across the river from ORGDP is used for fish population studies and is one of the best areas for collecting spawning carp. Embayment Pond (area $X-3$ ) just below Grassy Creek and above Gallaher Bridge is used for collecting spawning carp. A portion of Poplar Creek (area X-4), approximately $200 \mathrm{~m}$ upstream from the mouth, is used for fish population studies and as an aquatic monitoring station. Clinch River Mile 11 (area $X-5$ ) is used for fish population studies and as an aquatic monitoring station for the three-plant assessment. The mouth of Ellis Creek (area X-6), located at mile 4.3 on Poplar Creek, is used for fish population studies and as an aquatic monitoring station for the three-plant assessment. The segment $50 \mathrm{~m}$ above the convergence of Poplar Creek with the East Fork of Poplar Creek is used for fish population studies and as an aquatic monitoring station for the three-plant assessment.

Melton Lake Waterfowl Habitat. This site (area XII) has the attractive feature of combined open upland habitat (pasture), shoreline, and open-water rest areas. Conditions are conducive to establishing resident waterfowl populations. Migrants are also attracted to this site. Both resident and migrant waterfowl populations are resources for studies of potential environmental impacts related to differenit energy technologies. The major emphasis at present is the establishment of Canada geese on the Melton Hill reservoir. This effort involves TVA, the State of Tennessee Wildlife Agency, and environmental research groups in ERDA.

Wildlife Refuge $(K-25)$. The ponds (area 0811) on the south side of ORGDP, including the adjacent lowlands, are reserved for natural wildlife refuge. This area is a regular habitat for a population of coots and other wildfowl. Concomitant use is made of the area as a natural study location for ecological observation and experimentation. The tract includes about 170 acres (69 ha). 
Research Facilities of the Comparative Animal Research LaDoratory (CARL)

Facilities used in support of CARL's research. programs are summarized in Map 8 and Table 5. CARL, with its land and facilities, represents a unique ERDA laboratory well suited to carry out programs that could not be accomplished (or only with great difficulty and expense) elsewhere. Specific data from animal research are needed to define the risk to man from energy-related environmental toxic agents. Without agriculturaliy improved 1 and and the programs this land supports, these data might not be developed.

Programs at CARL include studies on the metabolism and effects of energy-related toxic agents in a variety of mammalian species, including small laboratory rodents, carnivores, and large domestic animals, such as swine, sheep, cattle, and horses. The large domestic animals are used not only for critical studies on the contamination of man's food chain but also (because of their large size, long life-span, and long gestation period) for interspecies comparisons designed to better extrapolate from experimental animal data to man. These species require agriculturally improved 1 and for maintenance of healthy breeding herds, and the 1 ands identified in Map 8 are required for this purpose.

In addition to agriculturally improved 1 and, an area has been identified for future ecological studies in cooperation with the Environmental Sciences Division (ORNL) and with the Forestry and Wildlife Department of the University of Tennessee Agricultural Experiment Station (area 1, Map 8). This area allows control of wildlife populations, management and control of woodland areas, and appropriate management of agricultural land. These areas must be contiguous, and strict animal and personnel control must be exercised.

Areas currently being used to support the CARL program are described below. Acreage data for the tracts are summarized in Table 5. Lands cited below are shown on Map 8.

Gallaher Bend contains 102 acres (41 ha) of good-quality pasturel and and 280 acres ( $113 \mathrm{ha}$ ) of woodland. There are no facilities other than fencing on this site. This area is used principally for the pasturing of cattle. The area has been identified and should be reserved for future studies on the environmental impact of energyrelated environmental pollutants as they relate to agriculture, forestry, and wildlife management. Of all the lands of the Oak Ridge Reservation, this peninsula, almost entirely surrounded by water, has the unique potential for these critical studies. Not only are wildlife species isolated and contained, but this is one of the best environments for small mammals and contains integrated pastureland and woodland for interaction studies. Large-scale studies on the distribution and transport of energy-related environmental pollutants are being initiated on this area. 
Table 5. Programmatic lands assigned to CARL

\begin{tabular}{|c|c|c|c|c|c|c|}
\hline & & \multicolumn{3}{|c|}{ Programmatic Land } & \multirow[b]{2}{*}{$\begin{array}{l}\text { Other } \\
\text { woodland } \\
\text { (ha) }\end{array}$} & \multirow[b]{2}{*}{$\begin{array}{l}\text { Total } \\
\text { (ha) }\end{array}$} \\
\hline & & $\begin{array}{l}\text { Pastureland } \\
\text { a nd/or } \\
\text { cropland } \\
\text { (ha) }\end{array}$ & $\begin{array}{l}\text { Lots } \\
\text { etc. } \\
\text { (ha) }\end{array}$ & $\begin{array}{l}\text { Woodland } \\
\text { within fenced } \\
\text { boundaries } \\
\text { (ha) }\end{array}$ & & \\
\hline & Gallaher Bend & 41 & & 8 & 105 & 154 \\
\hline 2. & Freels Bend & 128 & 13 & 32 & 144 & 317 \\
\hline 3. & Solway Bend/Bethel Valley & 45 & $7^{a}$ & 36 & 113 & 200 \\
\hline & Laboratory Area & & $32^{b}$ & & & 32 \\
\hline 5. & Chestnut Ridge & 141 & 4 & 100 & 28 & 273 \\
\hline 6. & Compartment "A" & $81^{c}$ & 1 & 27 & & 109 \\
\hline & Compartment "B" & 71 & 2 & 23 & & 96 \\
\hline 8. & Compartment "C" & 69 & 4 & 15 & & 88 \\
\hline 9. & Compartment "D" & 53 & 4 & 13 & 16 & 86 \\
\hline \multirow[t]{2}{*}{10.} & Compartment "E" & 60 & 18 & 4 & 97 & 179 \\
\hline & Total & 689 & 85 & 257 & 503 & 1534 \\
\hline
\end{tabular}

ancludes 5 ha occumpied by dwellings.

$\mathrm{b}_{\text {Includes ORAU animal facilities. }}$

${ }^{C_{E x c l u d e s}} 12$ ha to be transferred to the City of Oak Ridge. 
Freels Bend contains 316 acres (129 ha) of good-quality pasture7 and and cropland, 32 acres ( $13 \mathrm{ha}$ ) of lots, and 435 acres (176 ha) of woodland. Facilities include six barns, low-dose-rate and highdose-rate irradiation facilities, two sheds, a silo, and a unique log house of historical interest.

The area is used principally for irradiation of large animals, maintenance of caesarian-derived SPF swine, maintenance of ageirradiated burros, maintenance of breeding sheep flocks, pasturing of cattle, and production of hay and corn silage. The area is unique for these uses because of the relatively high fertility of the cleared land, isolation from other land areas by dense woodland and water, and access by a single road over a causeway. Thus sheep are safe from wild dogs, SPF swine are safe from microbial contamination, and aged burros are safe from the stresses of dogs and people.

Solway Bend-Bethel Valley contains 111 acres (45 ha) of pasture7 and and cropland, 18 acres ( $7.3 \mathrm{ha}$ ) of lots, and 346 acres ( $140 \mathrm{ha}$ ) of woodland. Facilities include two general-purpose barns, one swine barn with small laboratory, and two swine sheds. This area is used primarily for maintaining experimental swine in isolation, for maintaining burros in a lifetime study, and for pasturing cattle. Some hay is produced.

The Laboratory Area contains 79 acres ( 32 ha). This area contains CARL's principal research facilities: the main laboratory and office building, a surgery building, an autopsy building, two greenhouses, an equine building, a cattle, sheep, and swine nutritional facility, swine farrowing and rearing facilities, radioisotope laboratory, five barns, a feed mill, carpentry shop, machine shop and storage facility, cold storage building, warehouse, and sewer plant.

Ches tnut Ridge contains 348 acres ( $141 \mathrm{ha}$ ) of fair- to goodqual ity pastureland, 10 acres ( 4 ha) of lots and 316 acres (128 ha) of woodland. Facilities include three barns, two concrete trench silos, machinery shed, underground gasoline tank with pump, and a pneumatic water system. This land is used principally for the pasturing of cattle and for hay and silage production.

Compartment A contains 200 acres ( $81 \mathrm{ha}$ ) of fair-quality pastureland, 2 acres ( $1 \mathrm{ha}$ ) of lots, and 66 acres ( $26 \mathrm{ha}$ ) of woodland. Facilities include a shed and a silo. The land is used principally for the pasturing of cattle and winter feeding of the cattle herd. This is particularly valuable pastureland because of its nearness to the main laboratory facilities, which reduces labor costs during the winter months when feeding is required. It is extremely important that this land be preserved. 
Compartment B contains 175 acres ( $71 \mathrm{ha}$ ) of fair-quality pastureland, 5 acres ( $2 \mathrm{ha}$ ) of lots, and 58 acres $(23 \mathrm{ha})$ of woodland. Facilities include one barn and a corral. The principal use is the pasturing of cattle.

Compartment C contains 171 acres (69 ha) of fair-quality pastureland and cropland, 10 acres ( $4 \mathrm{ha}$ ) of lots, and 36 acres ( 16 ha) of woodland. Facilities include a barn and a silo. This land is used principally for the pasturing of cattle and for hay production.

Compartment D contains 130 acres ( $53 \mathrm{ha}$ ) of fair-quality pastureland and crop 7 and, 10 acres ( 4 ha) of lots, and 71 acres (29 ha) of woodland. Facilities include a barn and a machinery shed. This land is used principally for the pasturing of cattle and for hay production.

Compartment E contains 149 acres (60 ha) of cropland and pastureland, 44 acres (18 ha) of lots and plot land, and 250 acres (101 ha) of woodland. Facilities include two small barns, one barn especially designed for raising calves, one large feeding barn with silo, the agronomy fieldhouse, a machinery shed, and a shade house. The principal uses of the area are production of hay and silage crops, plant science research [20 acres ( $8 \mathrm{ha})]$, and cattle pasture and maintenance.

\section{FUTURE RESOURCE REQUIREMENTS FOR PROGRAMMATIC RESEARCH IN ENVRIONMENTAL SCIENCES}

As more spesific. dat.a are required on the envirnnmental hehavior of energy-related toxic agents and as the effects of these agents on agriculture, forests wildlife and humans are identified, newer, more sophisticated experiments must be conducted to assess total impacts on ecosystems on which man depends. Land and water possessing characteristics necessary for such studies are rare. Not only must it have the necessary qualities suitable for agriculture and forestry management with the necessary wildlife habitats, but it must also permit isolation and containment for environmental control. Several such areas exist on the reservation, and the following sites will be used, as needed, for ERDA's programmatic research in environmental sciences.

Thirteen sites have been identified for future use in anticipated projects. These sites [0801, 0913, 0923, 7733 (Map 6); VI, VIII, XI, XII (Map 7 ); and 0812,0918, 0922,7732,7734 (Legend for Map 6)] have been selected on the basis of geologic, edaphic, aquatic, and biotic characteristics and on the basis of how the adjacent lands relate to potential energy technologies. These 13 areas presently are undisturbed, to the extent that this is compatible with other land-use needs, to maintain the desired site characteristics for projected and potential environmental science research. Selected sites are described below. 
Raccoon Creek (0801) is the only stream remaining on the reservation that can serve as a control stream for aquatic studies. It has served as a collection site for aquatic organisms for a number of years. Within the proposed Raccoon watershed are numerous subwatersheds on the south slope of Haw Ridge, some of which have been included in the descriptions of unique natural areas. The watershed is one of the few that is not heavily polluted or impacted by construction. In view of the commitment of Grassy Creek to the Clinch River Breeder Reactor site and the possible impact by EXXON, the Raccoon Creek watershed will be used as an experimental reference site in aquatic research.

McNew Hollow (0913) is the on ly marsh habitat of any significance on the reservation and represents a unique research area for the assessment of impacts on inland wetlands.

The West Branch of White Oak Creek (area VI) will be impounded to ensure a constant water supply for experimental ponds used in aquatic research. In addition, about 40 small ponds are planned along West Branch between Bethel Valley Road and Haw Ridge.

The Scarboro Embayment and Kerr Hollow (area VIII) serve as a collecting site for aquatic organisms. Drainage from agricultural lands and from a small chemical dump (in a quarry) provide a different water-quality regime, and this site will be used as a future monitoring station.

Gum Branch (0923) east of Walker Branch Watershed on Chestnut Ridge. The Gum Branch area or subunits thereof is planned for use in future expansions of environmental programs requiring soils and geology similar to the present Walker Branch site but with different vegetation. Habitats include old-growth forest, pasture, and transmission-line corridors.

East Fork Poplar Creek (area XI) represents the only sizeable intact and nondisturbed floodplain on the reservation. Although it contalns fertlle suil, lhe area is not eurrently being used for agriculture but contains a 30-year second-growth forest with extensive forest communities typical of east Tennessee floodplains. This site is near ORGDP and the proposed Exxon site. This tract should be retained for environmental science research in support of these energy-related technologies. 
THIS PAGE

\section{WAS INTENTIONALLY LEFT BLANK}


ORNL/TM-5352

Distribution Category UC-11

INTERNAL DISTRIBUTION

1-25. S. I. Auerbach

26. B. S. Ausmus

27. B. G. Blaylock

28. E. A. Bondietti

29. D. M. Bradburn

30. R. W. Brocksen

31-40. R. L. Burgess

41. S. W. Christensen

42. C. C. Coutant

43. R. B. Craig

44-54. R. C. Dahlman

55. S. Draggan

56. J. 0. Duguid

57. L. L. Dye

58-68. J. W. Elwood

69. N. T. Edwards

70. L. D. Eyman

71. C. W. Francis

72. W. Fulkerson

73. R. H. Gardner

74. C. T. Garten

75. C. W. Gehrs

76. F. G. Goff

77. J. M. Giddings

78. T. Grizzard

79. W. F. Harris

80. G. S. Henderson

81. S. G. Hildebrand

82. F. 0. Hoffman

83. J. W. Huckabee

84. J. R. Hyndman

85. D. R. Jackson

86. D. G. Jacobs

87. W. C. Johnson

88. S. V. Kaye

89-99. J. T. Kitchings

100. R. L. Kroodsma

101. S. E. Lindberg
102. L. K. Mann

103. R. K. McConathy

104. S. B. McLaught in

105. R. B. McLean

106. J. S. Olson

107. R. J. 01son

108. R. V. O'Neill

109. B. R. Parkhurst

110. Herman Postma

111-121. D. E. Reichle

122. C. R. Richmond

123. P. S. Rohwer

124. M. S. Salk

125. R. K. Schreiber

126. D. S. Shriner

127. H. H. Shugart

128. J. D. Story

129. R. H. Strand

130. E. G. Struxness

137. J. S. Suffern

132. T. Tamura

133. F. G. Taylor, Jr.

134. J. E. Till

135. D. E. Todd

136. J. R. Trabalka

137. R. R. Turner

138. R. I. Van Hook

139. W. Van Winkle

140. D. C. West

141. J.P. Witherspoon

142. E. J. Witkowski

143. Biology Library

144-145. Central Research Library

146-147. Laboratory Records Department

148. Laboratory Records, ORNL-RC

149. ORNL $Y-12$ Technical Library

150. Document Reference Department 


\section{EXTERNAL DISTRIBUTION}

151. M. Bird, UT-ERDA Comparative Animal Research Laboratory, Oak Ridge, TN 37830

152. I. L. Brisbin, Savannah River Ecology Laboratory, Drawer E, Aiken, SC 29801

153. E. J. Cahoon, ERDA, Savannah River Operations Office, P. 0. Box A, Aiken, SC 29801

154. R. Clements, Puerto Rico Nuclear Center, Mayaquez, PR 00708

155. R. M. Darne11, Department of Oceanography, Texas A \& M University, College Station, TX 77843

156. Jere Davis, US Nuclear Regulatory Commission, Washington, DC

157. P. B. Dunaway, ERDA Nevada Operations Office, Las Vegas, NV 89114

158. A. S. Fege, Division of Biomedical and Environmental Research, ERDA, Washington, DC 20545

159. J. F. Franklin, Forest Science Laboratory, Oregon State University, P. 0. Box 887, Corvallis, OR 97730

160. R. FrankTin, Division of Biomedical and Environmental Research, ERDA, Washington, DC 20545

161. D. W. Gooda11, CSIRO Div. of Land Resources Management, Private Bag, P. 0., Wembley, Western Australia 6014

162. R. G. Jordan, Union Carbide Corporation, Nuclear Division, Y-12 Plant, Oak Ridge, TN 37830

163. J. R. Langley, ERDA, Oak Ridge Operations, Oak Ridge, TN 37830

164. G. M. Lauff, W. K. Kellogg Biological Station, Michigan State University, Hickory Corners, Michigan 4.9060

165. J. L. Liverman, Division of Biomedical and Environmental Research, ERDA, Washington, DC 20545

166. Frank Lowman, US Nuclear Regulatory Commission, Washington DC 20545

167. B. Manowitz, Brookhaven National Laboratory, Upton, NY 11973.

168. 0. D. Markham, ERDA, Idaho Operations Office, Idaho Falls, ID 83401

169. J. F. McCormick, Director, Graduate Program in Ecology, University of Tennessee, Knoxville, TN 37916

170. M. Mitche11, Union Carbide Corporation, Oak Ridge Gaseous Diffusion Plant, Oak Ridge, TN 37830

171. W. S. Osburn, Division of Biomedical and Environmental Research, ERDA, Washington, DC 20545

172. William A. Reiners, Ecosystem Studies Program, National Science Foundation, Washington, DC 20550

173. J. J. Reisa, Council on Environmental Quality, 722 Jackson Place, Washington, DC 20006

174. W. H. Rickard, Battelle Pacific Northwest Laboratory, Rich1 and, WA 99352

175. Paul Risser, Botany Department, University of Oklahoma, Norman, OK 73069

176. M. Saunders, Union Carbide Corporation, Y-12 Plant, Oak Ridge, TN 37830 
177. D. Spruge1, Agronne National Laboratory, Chicago, IL 60439

178. R. R. Sharitz, Savannah River Ecology Laboratory, Drawer E, Aiken, SC 29801

179. M. Smith, Savannah River Ecology Laboratory, Drawer E, Aiken, SC 29801

180. Jeff Swinebroad, Division of Biomedical and Environmental Research, ERDA, Washington, DC 20545

181. James T. Tanner, Graduate Program in Ecology, University of Tennessee, Knoxville, TN 37916

182. R. Watters, Division of Biomedical and Environmental Research, ERDA, Washington, DC 20545

183. J. Wing, Oak Ridge Operations, ERDA, Oak Ridge, TN 37830

184-194. H. E. Walburg, Comparative Animal Research Laboratory, Oak Ridge, TN 37830

195. Research and Technical Support Division, ERDA-ORO, Oak Ridge, TN 37830

196-411. Given distribution as shown in TID-4500 under category UC-11, Environmental Control Technology and Earth Sciences. 